\title{
Ground Disposal of Oil Shale Wastes: A Review with an Indexed Annotated Bibliography Through 1976
}

by

R. C. Routson

R. M. Bean

December 1977

Prepared for the

U.S. Department of Energy

under Contract EY-76-C-06-1830 
NOTICE

This report was prepared as an account of work sponsored by the United States Government. Neither the United States nor the Department of Energy, nor any of their employees, nor any of their contractors, subcontractors, or their employees, makes any warranty, express or implied, or assumes any legal liebility or responsibility for the accuracy, completeness or useruiness of any information, apparatus, procluct or process disclosed, or represents that its use would no: infrinze frivately owned rights.

The views, opinions and conclusions contained in this report are those of the contractor and do not necessarily represent those of the United States Covernment or the United States Department of Energy.

\author{
PACIFIC NORTHWEST LABORATORY \\ operated by \\ BATTELLE \\ ior the \\ UNITED STATES DEP.ARTMENT OF ENERCY \\ Under Contract EY-76-C-06-1030
}
Printed in the Uinited Status of America
Avallabile from
National Techr ical Information Service
United States Deoartment of Commerce
5285 Port Royal Road
Soringfield, Virginia 22151

Price: Printed $\operatorname{Com} s$ *: Micratiche $\$ 300$

NIIS

Ppges

Sefling Price

oet onis

2450

$026-050$

35.00

$057-075 \quad 55.50$

(5)6.110 SE $\quad$ SE 00

v01.7.s $\quad$ SE.50

s7

$757.725 \quad 5775$

$176-2100 \quad 38.50$

$201-2.35+36.75$

$226-250 \quad 55.00$

$257-255$

$275.700 \quad 510.25$ 
33679000517468

PNL-2200

UC-91

GROUND DISPOSAL OF OIL SHALE WASTES:

A REVIEW WITH AN INDEXED ANNOTATED

BIBLIOGRAPHY THROUGH 1976

by

R. C. Routson

R. M. Bean

December 1977

BATTELLE

Pacific Northwest Laboratories

Richland, Washington 99352 


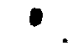

$\bullet$

•.

- 
CONTENTS

INTRODUCTION AND SUMMARY .

OIL SHALE TECHNOLOGY

DESCRIPTION OF OIL SHALES

LOCATION AND ESTIMATED POTENTIAL OIL SHALE

PRODUCT RESERVES

HISTORY

OIL SHALE EXTRACTION PROCESSES

MINING

RETORTING .

PRODUCT PROPERTIES AND PREREFINING OPERATIONS

PRESENT STATUS OF OIL SHALE COMMERCIALIZATION

ENVIRONMENTAL ASPECTS OF THE POTENTIAL DISPOSAL OF

OIL SHALE WASTES TO GROUND

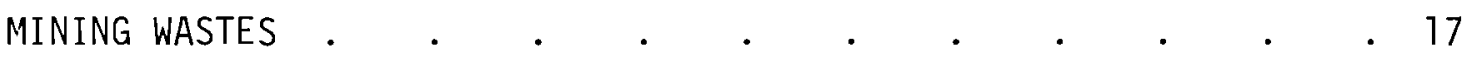

RETORT RESIDUALS.$\quad \cdot \quad \cdot \quad \cdot \quad \cdot \quad \cdot \quad \cdot \quad \cdot \quad \cdot \quad \cdot 18$

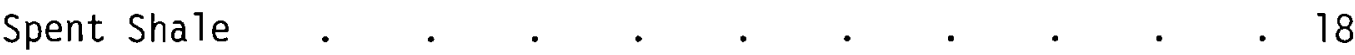

Retort Wastes . . . . . . . . . . . 20

Offgas Scrubber Wastes . $. \quad . \quad . \quad . \quad . \quad . \quad .21$

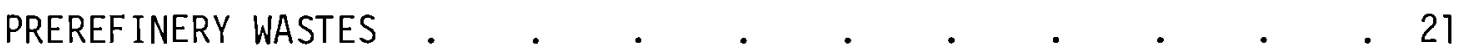

ANNOTATED BIBLIOGRAPHY

SECTION I: ENVIRONMENTAL ASPECTS OF THE POTENTIAL

DISPOSAL OF OIL SHALE WASTES TO GROUND. . . . . 23

SECTION II: OIL SHALE TECHNOLOGY • INDEXES

WORD INDEX.$\quad \cdot \quad \cdot \quad \cdot \quad \cdot \quad \cdot \quad \cdot \quad \cdot \quad \cdot \quad \cdot \quad \cdot 155$

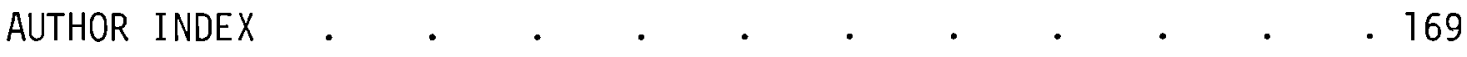




\section{FIGURES}

1. 0il Shale Deposits of the United States . . . . . . . 4

2. Oil Shale Deposits in the Green River Formation of Colorado, Utah, and Wyoming . . . . . . . . . 5

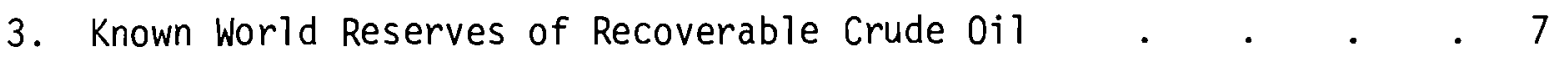

4. Known World Reserves of Recoverable Coal Supplies . . . . 7

5. Known World Reserves of Recoverable 0il Shale . . . . 8

6. Known World Reserves of Recoverable Fossil Fuels . . . . 8

\section{TABLES}

1. Estimated Average Mineral Compositions of an 0 il Shale Section Averaging $85 \mathrm{l} / \mathrm{MT}(25 \mathrm{gal} / \mathrm{T})$ of Syncrude Product . . . . 3

2. Estimated Chemical Composition of Organic Matter from an $0 \mathrm{il}$ Shale Section Averaging 85 1/MT (25 gal/T) of Syncrude Product . 3

3. Properties of Shale 0ils and Conventional Petroleum Crude oils. 


\author{
GROUND DISPOSAL OF OIL SHALE WASTES: \\ A REVIEW WITH AN INDEXED ANNOTATED BIBLIOGRAPHY
}

INTRODUCTION AND SUMMARY

For the United States to achieve energy independence in the foreseeable future, it is essential that all U.S. energy resources be fully utilized within defined environmental limits. 0il shale is one of the most abundant energy sources, potentially as large as all of the known world's petroleum reserves (Petzrick, 1975). The technology required to demonstrate commercial feasibility is available; however, environmental, economic, legislative, and policy constraints have delayed construction of prototype plants (Science, 1973). This review covers the available literature concerning ground-disposed wastes and effluents of a potential oil shale industry. Ground disposal has been proposed for essentially all of the solid and liquid wastes produced (Pfeffer, 1974). Since an oil shale industry is not actually in operation, the review is anticipatory in nature. The section, 0il Shale Technology, provides essential background for interpreting the literature on potential shale oil wastes and the topics are treated more completely in the section entitled Environmental Aspects of the Potential Disposal of 0il Shale Wastes to Ground. The first section of the annotated bibliography cites literature concerning potential oil shale wastes and the second section cites literature concerning oil shale technology. Each section contains references arranged historically by year. An index is provided to assist the reader in finding oil shale publications with information and data upon a particular subject. 


\section{OIL SHALE TECHNOLOGY}

Recent comprehensive reviews of the shale oil and oil shale technology include Sladek (1974, 1975a, 1975b) and Science (1973). Bibliographies of oil shale research studies include Rogers (1974), Hundemann (1976), and Stanford Research Institute staff (1976) and Anon (1976).

\section{DESCRIPTION OF OIL SHALES}

0il shale is neither a shale nor contains oil. 0il shales are geologically classified as marlstones because of a large percentage of carbonates. Synthetic crude oil (syncrude) is produced only after addition of heat (retorting) and prerefining the retort product. Average mineral composition of oil shales averaging 85 liters/metric ton (1/MT) are given in Table 1. These shales are composed of about $86 \%$ mineral matter and $14 \%$ organic matter (Schramm, 1970). Organic matter that occurs in oil shale is a resinous solid, not an oily liquid. Table 2 gives the chemical composition of the organic matter. The organic matter in $0 i 1$ shale is composed of bitumen, $210 \%$ and kerogen, $290 \%$ (Sladek, 1974; Hubbard and Robinson, 1950). Bitumen is a heteroatomic polymer soluble in many organic solvents. Kerogen is a heteroatomic polymer having a molecular weight of greater than 3000 and is insoluble in most organic solvents. The kerogen subunits are crosslinked to one another by oxygen and sulfur giving kerogen a continuous three dimensional molecular structure throughout an oil shale formation (Atwood, 1973). The minerals are scattered throughout the kerogen network. Kerogen and bitumen are thermally unstable and, with the application of heat $\left(250^{\circ} \mathrm{C}\right.$ or greater), thermally decompose to form gaseous and liquid products that can be refined to syncrude.

\section{LOCATION AND ESTIMATED POTENTIAL OIL SHALE PRODUCT RESERVES}

Figure 1 gives the location of known oil shale deposits in the U.S.; however, only the Green River Formation is considered to contain deposits of present commercial interest (Figure 1 and Figure 2). Areas shown in 


\section{TABLE 1. Estimated Average Mineral Compositions of an $0 i 1$ Shale Section Averaging 85 1/MT (25 gal/T) of Syncrude Product (Schramm, 1970).}

Estimated mineral composition $\%$

Carbonates principally dolomite 48

Feldspar 21

Quartz 13

Clay principally illite 13

Analcite 4

Pyrite

TABLE 2. Estimated Chemical Composition of Organic Matter from an 0 il Shale Section Averaging 85 1/MT (25 gal/T) of Syncrude Product (Schramm, 1970).

\begin{tabular}{|c|c|}
\hline U1timate composition & $\%$ \\
\hline Carbon & 81 \\
\hline Hydrogen & 10 \\
\hline Nitrogen & 2 \\
\hline Sulfur & 1 \\
\hline Oxygen & 6 \\
\hline Total & 100 \\
\hline
\end{tabular}

Figure 2 represent approximately 11 million acres. The federal government has title to approximately $80 \%$ of this land.

Although oil shale resource estimates vary widely, it is indeed a large resource even by the most conservative estimates and are of a similar 


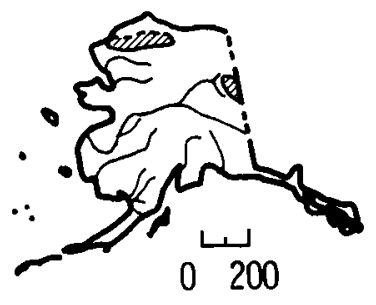

MILES

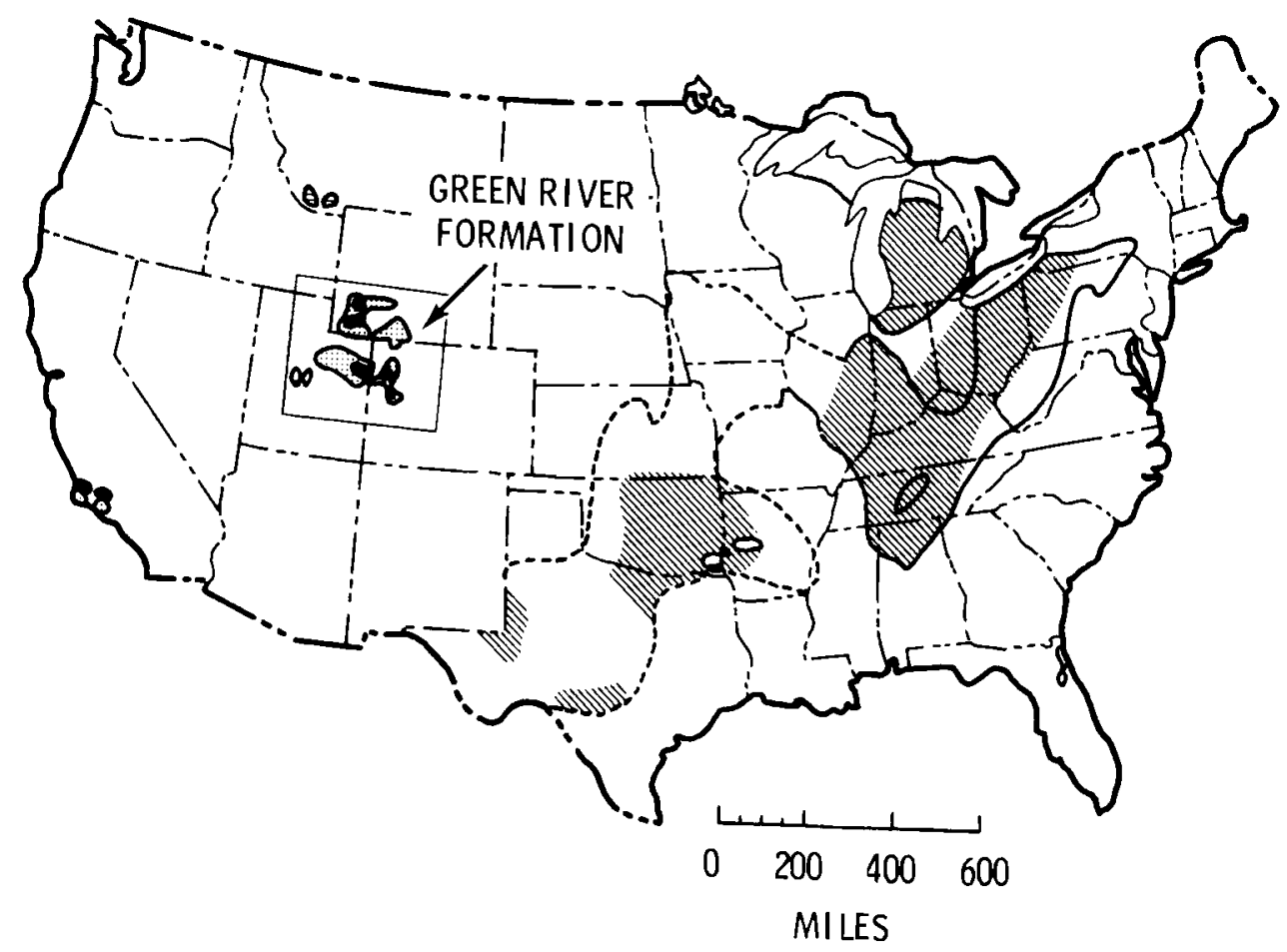

$(2$ TERTIARY DEPOSITS

GREEN RIVER FORMATION IN COLORADO, UTAH, AND WYOMING; MONTEREY FORMATION, CALIFORNIA; MIDDLE TERTIARY DEPOSITS IN MONTANA. BLACK AREAS ARE KNOWN HIGH-GRADE DEPOSITS.

\section{MESOZOIC DEPOSITS}

MARINE SHALE IN ALASKA

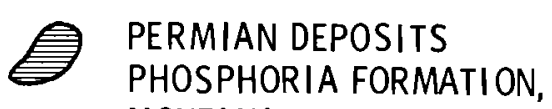
MONTANA

DEVONIAN AND MISSISSIPPIAN DEPOSITS (RESOURCE ESTIMATES INCLUDED FOR HACHURED AREAS ONLY). BOUNDARY DASHED WHERE CONCEALED OR WHERE LOCATION IS UNCERTAIN.

FIGURE 1. Oil Shale Deposits of the United States (Modified from D. C. Duncan and V. E. Swanson. 1965. Organic-rich shale of the United States and world land areas. U.S. Geol Surv., Circ. 523, 30 pp.) 

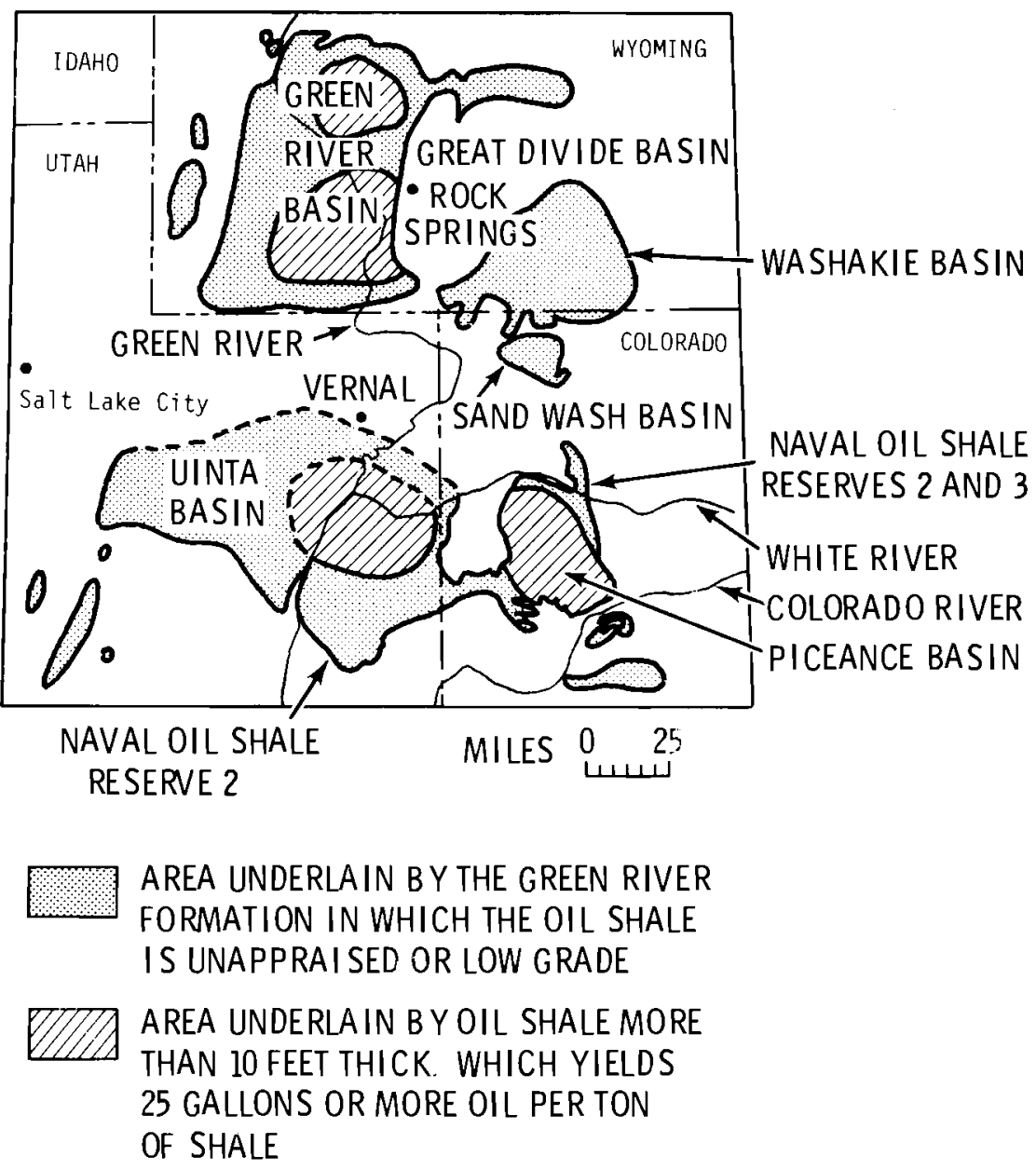

FIGURE 2. 0il Shale Deposits in the Green River Formation of Colorado, Utah, and Wyoming (Modified from D. C. Duncan and V. E. Swanson. 1965. Organic-rich shale of the United States and world land areas. U.S. Geol Surv., (irc. 532,30 pp.)

magnitude to the world's known petroleum reserves. Sladek (1974) discusses the potential Green River oil shale resource. Sladek reported:

"The rich zones of Piceance Basin in Colorado (Fig. 2) contain a potential resource of between 320-420 billion barrels of shale oil. The Uinta Basin in Utah and Colorado (Fig. 2) may yield as much as 321 billion barrels of shale oil, and the Wyoming deposits, although relatively unexplored, may contain yet another 300 billion barrels. Altogether, a potential resource of over a trillion barrels of shale oil has been documented in recent literature. A more liberal approach 
by the Department of the Interior in 1968 (National Petroleum Council, 1972) placed the potential oil shale resources of the Piceance Basin alone at over 1.2 trillion barrels and predicted a total resource of 1.8 trillion barrels for the entire Green River Formation. Other estimates in the popular and scientific literature have placed the total resource at between 3 and 7 trillion barrels. - - - - There are several conditions that must be satisfied before a potential resource--such as a deposit of oil shale buried in colorado--can be considered a reserve, that is a viable source of recoverable energy. As in the thousands of tons of gold dissolved in the oceans of the world, the value of a resource is nil unless it can be developed without bankrupting the developer. In the case of oil shale, deposits that are too deeply buried, too thin, or too low in oil yield should not be included in a survey of oil shale reserves, since economic use of these deposits may be impossible."

Perhaps an even greater appreciation of the magnitude of the oil shale resource can be gained from the work of Petzrick (1975) who used the technique of "distorting the world map to proportion a country's size according to the relative amount of each fossil fuel resource available in that country (Figures $3,4,5$, and 6 ).* From Figure 3 it can be seen that the U.S. has only about $5 \%$ of the world known recoverable crude 011 . In contrast the U.S. presently uses about $33 \%$ of the world energy. To augment the present U.S. petroleum supplies, large quantities of crude are imported, with an attendant loss of control in times of national emergency. Figure 4 shows that the U.S. is indeed rich in coal resources. However, coal is an inherently dirty energy source and is not presently suitable as an automotive fuel, al though research is now underway in coal 1 iquefaction. Figure 5 shows that the U.S. is also rich in shale oil resources, having almost three-fourths of the world's known reserves. Additionally, shale oil can be refined to an automotive fuel. Figure 6 demonstrates that, including coal and shale oil, the

* from SHALE COUNTRY, published by Mountain Empire Publishing, Inc., Denver, Colorado. 


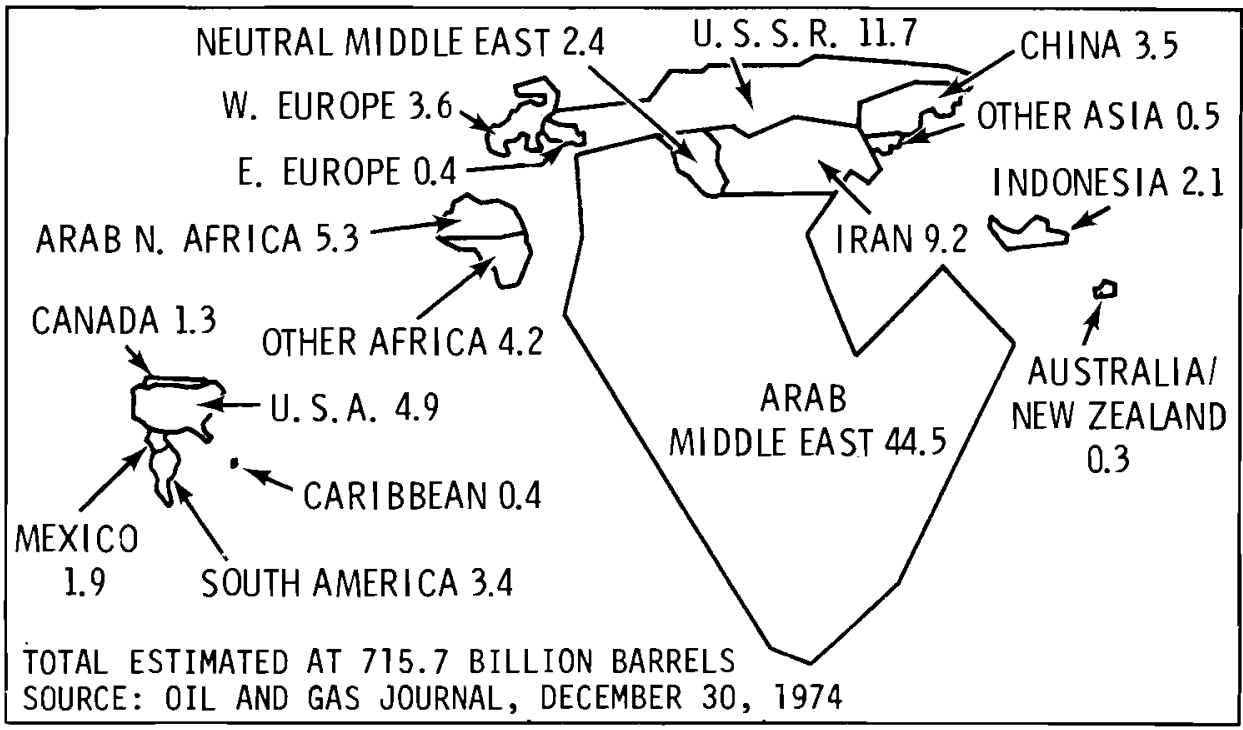

FIGURE 3. Known World Reserves of Recoverable Crude $0 i 1$ (From Petzrick, 1975)

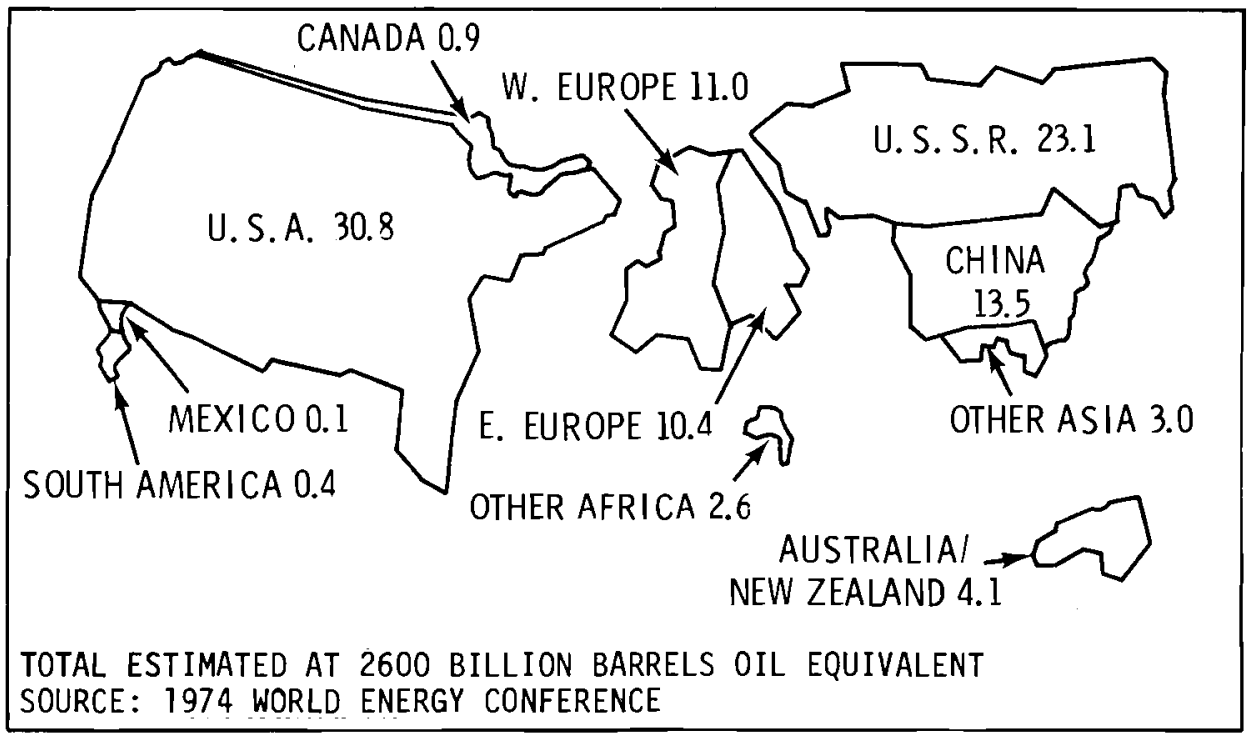

FIGURE 4. Known World Reserves of Recoverable Coa 1 Supplies (From Petzrick, 1975) 


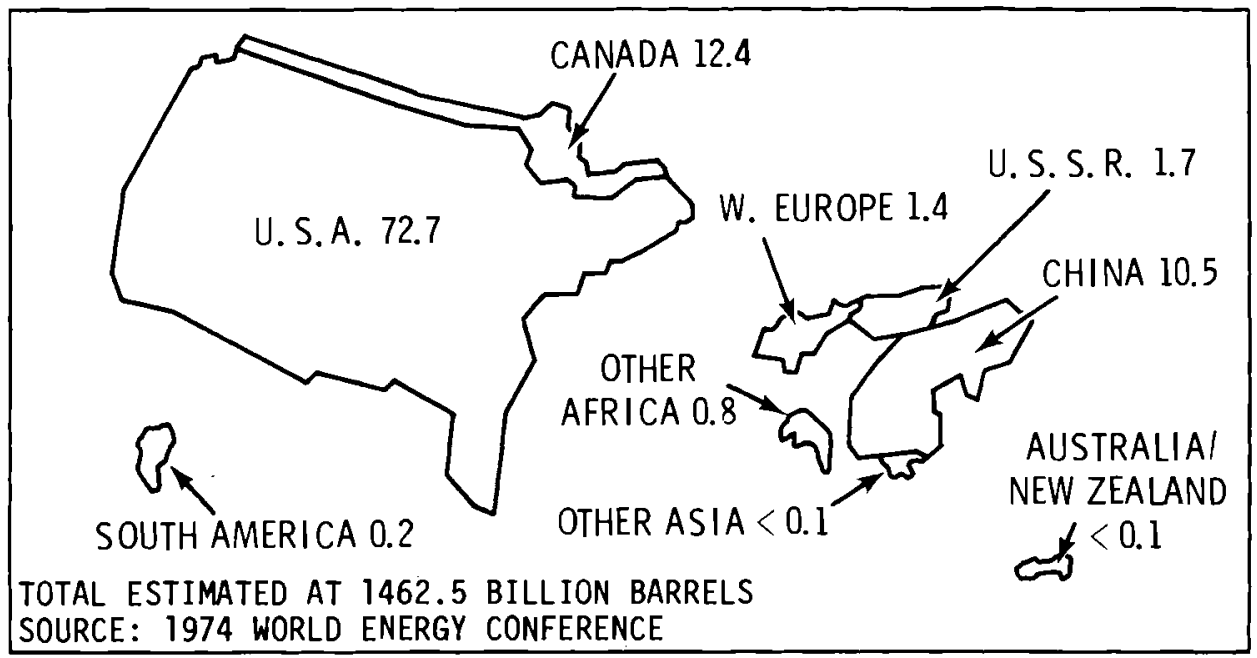

FIGURE 5. Known World Reserves of Recoverable 0il Shale (From Petzrick, 1975)

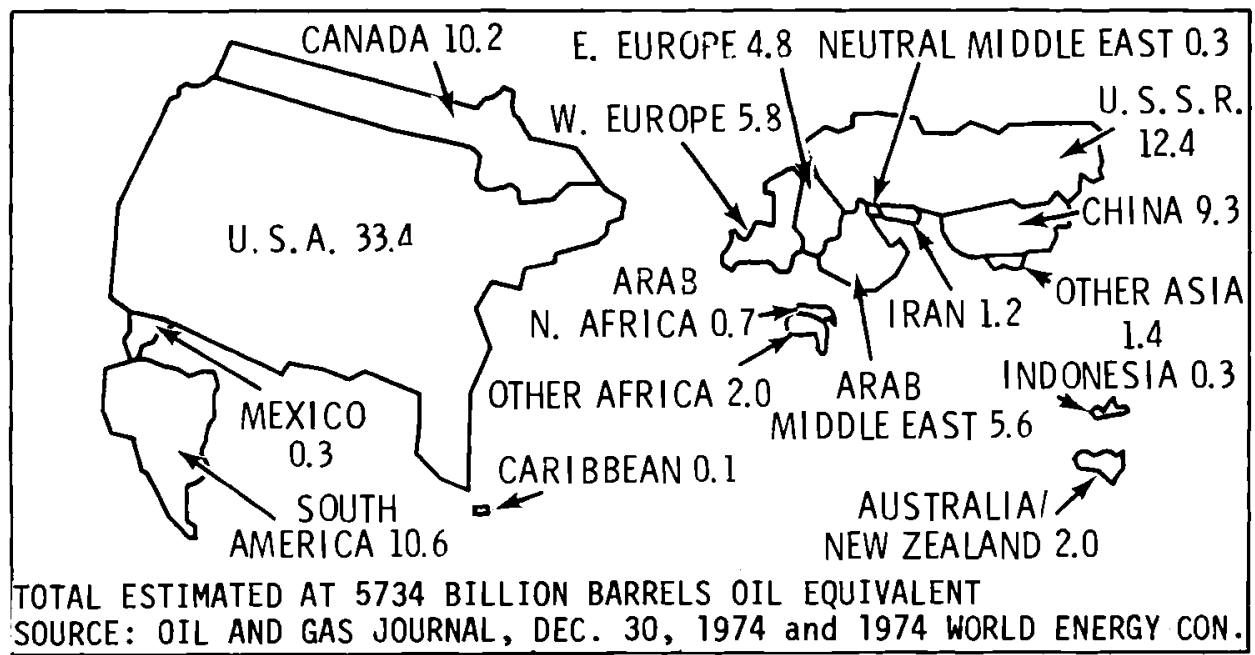

FIGURE 6. Known World Reserves of Recoverable Fossil Fuels (From Petzrick, 1975) 
U.S. has about $33 \%$ of the world's total fossil fuel or almost the same percentage of world energy that the U.S. uses. This strongly suggests, therefore, that the U.S. can obtain energy independence, but only if industry efficiently uses the vast coal and oil shale resources.

\section{$\underline{\text { HISTORY }}$}

Even before Mike Callahan's famed 1882 "housewarming" in Rio Blanco County, Colorado, there was a shale oil industry in the U.S. Mike Callahan built a fireplace of oil shale in a new house. When he started the first (and only) fire in the fireplace at a formal "housewarming," his fireplace and house burned to the ground (Carlton, 1975). This apparently was the origin of the nickname for oil shale as "the rock that burns." As early as 1855 the Mormons at Juab, Utah produced oil from oil shale (Carlton, 1975).

On several occasions in the U.S., oil shale has seemed on the edge of becoming a commercial reality. In every case, crude petroleum proved to be the more economical fuel and the fledgling oil shale industry died an economic death. Before 1859 the U.S. considered developing an oil shale industry in Appalachia but abandoned the idea when oil was discovered in Pennsylvania (NPC, 1972).

In 1915 and 1916 the USGS surveyed oil shale lands in the Green River Formation, and estimated that these deposits contained $40 \times 10^{9}$ available barrels of shale oil. This resulted in the filing of more than 30,000 mining claims, but the industry failed to develop because of the competition from crude oil. In 1925 the Bureau of Mines began to devise equipment and methods for mining and retorting oil shale near Rifle, Colorado. However, competition from the east Texas oil fields closed the project in 1929. During World War II, the Bureau of Mines was commissioned by the Navy to mine oil shale at Anvil Points, Colorado, in anticipation of petroleum shortages. Congress ceased appropriations for this effort in 1956 (Carlton, 1975). During the period of the Anvil Points operations, and until the leasing of the federal oil shale tracts in 1974, private industry made little effort to develop oil 
shale. However, research at the Laramie Bureau of Mines (now the Laramie Energy Research Center, USERDA) has been nearly continuous since 1919 (Rogers, 1974).

\section{OIL SHALE EXTRACTION PROCESSES}

$0 i 1$ shale processes can be divided into two general categories; those in which the shale oil is produced by pyrolysis in the shale formation (in situ), and those in which the shale is mined, and the oil extracted from the mined shale in aboveground retorts (ex situ). Recent reviews of oil shale extraction technology include Sladek (1974, 1975a), Science (1973) and a report by the National Petroleum Council (1972).

In in situ processing, the shale is fractured by either explosive or hydrostatic pressure. A portion of the shale organic material then is burned to obtain heat for retorting (Sladek, 1975a). An external fuel such as natural gas may be used to start and control the burning. The retorted shale oil is extracted by pumping in a manner similar to the extraction of crude petroleum. In situ processes may ultimately have certain advantages over ex situ processes including 1) avoidance of mining costs, 2) no solid waste disposal, 3) lower water requirements, and 4) amenability to low-grade shales (NPC, 1972). Disadvantages include: 1) difficulty of controlling combustion, 2) high drilling costs, 3) low recovery efficiencies, 4) difficulty of establishing the required porosity, and 5) possible contamination of aquifiers. Much shale occurs within the zone saturated and since spent shale is known to contain large amounts of soluble sodium ( $\mathrm{Na}$ ) and calcium ( $\mathrm{Ca}$ ) salts, in situ processing would pollute the ground water directly with such waste (Ward et a1., 1971). In addition large volumes of ground water may be contaminated by soluble organic material or radioactive material if nuclear explosives are used for rubbeling. The conclusion of a recent workshop was that in situ recovery was many years and many research dollars away from commercial reality (Penner, 1975). Some of the major objections to pure in situ recovery of shale oil are overcome by modified in situ recovery where a portion of shale is mined and retorted aboveground. This creates the needed pore space to assure adequate recovery of the in situ oil (Snyder et a1., 1975). 
Ex situ $0 i 1$ shale recovery processes (aboveground retorting) are simple in principal, but more complicated in application. These processes consist of mining the shale, grinding it to the size needed, heating the shale in a retort at high temperatures to convert the kerogen and bitumen to volatile organic products, collecting the volatiles in a condenser, and prerefining the product to produce a syncrude which can be refined in a manner similar to crude $0 i 1$ in existing refineries. The disposal of waste effluents include: mining wastes, spent shale, offgases, process waters, cooling waters, and prerefinery wastes. An annotated bibliography is available covering the engineering aspects of shale oil processing (Hundemann, 1976).

MINING

Underground and open pit mining techniques will require an estimated 1.4 $\times 10^{6} \mathrm{~T}$ /day of $0 i 1$ shale to operate the smallest economical plant $\left(10^{5}\right.$ bbl/day). A mine of this size will be larger than any mine presently operating in the U.S. (Sladek, 1975a). Open pit mining is economically attractive for some surface and near surface $0 i 1$ shales since nearly $100 \%$ of the $0 i 1$ shale can be recovered compared to a maximum of 50 to $70 \%$ for underground mines. Surface disturbance and its resulting environmental impact are the primary obstacles (Ert1, 1965). Because of large overburdens, a combination of open pit and underground methods may ultimately be used in certain cases.

Underground mining will probably be accomplished by the room-and-pillar method. This method consists of removing a portion of the shale from large underground rooms, leaving the remainder of the shale in place to act as pillars to support the roof. It is estimated that 30 to $50 \%$ of the shale will be left unmined by this technique (East and Gardner, 1964; Sladek, 1974). Completed mines of high grade shales will be likely candidates for further modified in situ mining. These mines will provide ready access for the placement of rubbeling charges and will obviate the porosity problems found in conventional in situ experiments. However, room-and-pillar mines will generally be deep which will make recovery of any in situ produced shale oil difficult. Both open pit and underground methods will require the disposal of extensive volumes of highly saline ground water during mining operations in certain 1ocations (Pfeffer and Kerr, 1974). 


\section{RETORTING}

Al though several categories of aboveground retorting have been proposed, only two classes of processes are under active consideration. These are the direct heating $(\mathrm{DH})$ and indirect heating (IH) processes. In the DH process, hot gases resulting from the combustion of a portion of the carbonaceous material in the shale within the retort $(\sim 435 \mathrm{C})$, are circulated through the oil shale. In the IH process, heat is transferred to the shale by contact with externally heated hot recyclable solids (265C). The Paraho process (DH), nearly ready for commercial operation (Piper, 1974), is a continuously operating version of the Bureau of Mines batch, gas-combustion (NTU) retort. Other possible commercial $\mathrm{DH}$ processes include three Union $0 \mathrm{il}$ retorting methods (Hartley, 1974) and the Superior $0 i 1$ circular-grate retort (Paxton, 1975). DH retorts handle mine-run shale requiring little grinding. Fines tend to plug $\mathrm{DH}$ retorts and thus briquetting is required (Sladek, 1975a). The efficient burning of residual carbon in the $\mathrm{DH}$ process results in a low carbon spent shale, reducing the potential for release of organic pollutants to the environment upon disposal. DH processes also tend to be mechanically simple compared to IH processes (Sladek, 1975a). The only IH process under consideration is the Tosco II process in which the oil shale is heated with externally heated reusable ceramic balls (Nevens et al., 1970). 0il yields from the Tosco II process are high and the process produces a commercially desirable, high BTU gas compared to that of DH processes. However, a large portion of this gas is reused within the process to heat the recyclable balls.

\section{PRODUCT PROPERTIES AND PREREFINING OPERATIONS}

Although product properties vary with type of retorting process, al 1 shale oils tend to be heavy viscous liquids with high pour points. Table 3 compares the properties of shale oils from proposed commercial processes with two crude petroleums (Hartley, 1974; Carver, 1964; Stevens et al., 1952). The pour point, viscosity, and nitrogen content are all significantly higher for the shale oils. The high pour point oils are unsuitable for transportation 
TABLE 3. Properties of Shale 0ils and Conventional Petroleum Crude 0ils (Hartley, 1974; Stevens et a1., 1952; Carver, 1964)

\begin{tabular}{|c|c|c|c|c|c|c|}
\hline & \multicolumn{4}{|c|}{ Raw Shale 0ils } & \multicolumn{2}{|c|}{ Petroleum Crude 0ils } \\
\hline & $\begin{array}{c}\text { Gas } \\
\text { Combustion } \\
\text { Retort }\end{array}$ & $\begin{array}{l}\text { NTU } \\
\text { Retort }\end{array}$ & $\begin{array}{l}\text { Union } \\
\text { "A" } \\
\text { Retort } \\
\end{array}$ & $\begin{array}{l}\text { Unjon } \\
\text { SGR } \\
\text { Retort }\end{array}$ & $\begin{array}{c}\text { Heavy Crude, } \\
\text { Santa Maria } \\
\text { Valley, } \\
\text { California }\end{array}$ & $\begin{array}{l}\text { High Quality } \\
\text { Crude, Aneth } \\
\text { Field, Utah }\end{array}$ \\
\hline $\begin{array}{l}\text { Specific } \\
\text { gravity at } 16 \mathrm{C}\end{array}$ & 0.943 & 0.935 & 0.945 & 0.925 & 0.973 & 0.823 \\
\hline API gravity & 18.6 & 19.8 & 18.2 & 21.5 & 14 & 40.5 \\
\hline Pour point, $C$ & 30 & 32 & 24 & 20.5 & -7 & 2 \\
\hline Viscosity, SUS & $\begin{array}{l}310 \text { at } \\
38 \mathrm{C}\end{array}$ & $\begin{array}{l}280 \text { at } \\
38 \mathrm{C}\end{array}$ & $\begin{array}{l}280 \text { at } \\
38 \mathrm{C}\end{array}$ & $\begin{array}{l}\text { Not } \\
\text { Available }\end{array}$ & $\begin{array}{l}215 \text { at } \\
50 C\end{array}$ & $\begin{array}{l}37 \text { at } \\
38 \mathrm{C}\end{array}$ \\
\hline $\begin{array}{l}\text { Sulfur, } \\
\text { weight }(\%)\end{array}$ & 0.69 & 0.74 & 0.71 & 0.7 & 5.0 & 0.14 \\
\hline $\begin{array}{l}\text { Nitrogen, } \\
\text { weight }(\%)\end{array}$ & 2.13 & 1.78 & 1.89 & 1.8 & 0.6 & $\begin{array}{c}\text { Not } \\
\text { Available }\end{array}$ \\
\hline
\end{tabular}

by pipeline or tanker without additional heating. The sulfur and nitrogen compounds tend to poison heavy metal catalysts used in refining processes (sladek, 1975b). Thus, retorting complexes will likely have prerefining facilities on site to reduce product viscosity and remove sulfur and nitrogen prior to pipeline transport.

A proposed complex could include holding tanks for retort product storage, a distillation column, a delayed coker, a hydrocracker for nitrogen removal, a Claus reactor for sulfur recovery, a steam reformer for hydrogen generation and product cleanup facilities (Katell and Wellman, 1974). A partially refined low sulfur, low nitrogen premium syncrude will be the resulting product, as well as a sulfur, ammonia and coke, which would have additional commercial value. 


\section{PRESENT STATUS OF OIL SHALE COMMERCIALIZATION}

The Science Policy Research Staff (1973) has concluded that "the processing of oil shale is within or near the range of economic feasibility." Several industry and government spokesmen have reached similar conclusions (Paxton, 1975; Eliason, 1975; Metz, 1974; Pfeffer, 1974; Sladek, 1975b; Cameron, 1974; Ligon, 1975). Considering the recent dramatic increases in world price of crude oil, why does the U.S. continue to have no commercial oil shale industry? The answer is complex but can be related to four factors: 1) high initial capital investments, 2) possible instability of world crude oil prices, 3) lack of clearly defined federal oil shale development policy, and 4) environmental considerations.

The proposed oil shale industry will be capital intensive, requiring an enormous initial investment which must be spread over the lifetime of the plant for the venture to be economically attractive (Cameron, 1974; Cooley, 1974; Clark and Varisco, 1974; Katell and Wellman, 1974). Estimates of $\$ 0.5-3 \times 10^{9}$ per 50,000 barrel per day aboveground plants seem to be reasonable (Katell and Wellman, 1974; Anon, 1975).

These large capital investments must be made in the face of uncertain world crude oil prices which are not determined on a competitive basis but are set arbitrarily by a cartel or oil producing nations. It is cheaper to drill for crude oil than to produce syncrude from oil shale (Sladek, 1975b). Crude oil can be produced at a profit for less than $\$ 1$ per barrel in the Middle East (Cooley, 1974). Thus the oil cartel can lower prices at will to make an oil shale operation unprofitable. To overcome this obstacle the Science Policy Research Division Staff (1973) concluded it would be possible to establish an oil shale industry if the federal government would do one or more of the following:

1. make low interest federal loans to private industry,

2. establish an independent federal agency to exploit federally owned oil shale deposits, 
3. establish a clearly defined national oil shale policy,

4. give tax credits to encourage private development, or

5. give grants or guarantee a fixed price per barrel through contract provisions.

To date, none of these steps have occurred. Congress has in fact failed to put the oil shale industry on the same footing as the petroleum industry. The present oil shale depletion allowance is $15 \%$ compared to the $221 / 2 \%$ for $0 i 1$ and gas (Cameron, 1974).

Strong environmental concerns have also added to the potential oil shale industry's problems. There are environmental uncertainties related to the disposal of spent shale and other residuals, restoration and revegetation of disturbed land, water supply, and air quality. These will be discussed in more detail in the next section. Given the above uncertainties no aboveground oil shale industry seems likely in the forseeable future. 
4

6 
ENV IRONMENTAL ASPECTS OF THE POTENTIAL DISPOSAL OF OIL SHALE WASTES TO GROUND

Research on oil shale technology has been conducted in the U.S. since 1919, largely under the leadership of the U.S. Bureau of Mines. However, most of the research reported in the literature is industry and product oriented (Rogers, 1974). Relatively little deals with potential liquid and solid oil shale wastes, the bulk of which are presently being proposed for ground disposal (Pfeffer and Kerr, 1974).

Essentially all of the anticipated liquid and solid oil shale wastes have been proposed for ground disposal (Pfeffer, 1974). Thus the potential wastes, liquid and solid, which may be disposed of to the ground, is equivalent to a list of all wastes produced. These are discussed under the following headings: 1) mining wastes, 2) retort residual wastes, and 3) prerefining wastes. In situ and modified in situ wastes are expected to be qualitatively similar to the aboveground retorting wastes; however, the amounts will undoubtedly be different from aboveground operations.

\section{MINING WASTES}

Overburdens from open-pit mining and mine dewatering from both open-pit and room-and-pillar mining could produce large volumes of waste. A single mine could produce $31 / 2$ billion $\mathrm{m}^{3}$ of overburden plus 39 billion $\mathrm{m}^{3}$ of low grade unusable shale (Ertl, 1965). In the center of Piceance Basin, open pit mines are contemplated even though the overburden in some areas has been estimated at more than $300 \mathrm{~m}$. The ratio of overburden to extractable ore (stripping ratio) is an important factor in the economics of mining operations. For oil shale, the economical stripping ratio is 1:2 (Sladek, 1975a), although it may be as high as 1:1 for coal mining (Ert1, 1965). Assuming a volume expansion of $25 \%$ during removal, a ratio of $1: 2$ represents approximately 3.0 barrels of overburden per barrel of shale oil. Primary disposal problems with overburden are associated with the potential leaching of solubles and erosion of stockpiled overburden during the temporary storage following mining, and revegetation following closure of open-pit mines (Fletcher 
and Baldwin, 1973). The research being conducted on coal overburdens will probably directly translate to oil shale (Persse, 1975; Donovan et al., 1976).

The large volumes of shale occurring in the saturated zone may be dewatered before mining. Unfortunately, some of the deeper ground water is saline and can not be disposed of to surface waters without treatment. Total dissolved solid concentrations of nearly $17,000 \mathrm{mg} / 1$ have been reported and are not uncommon. Discharge to saline deep well aquifers may be an acceptable disposal method for the most highly saline waste (Pfeffer and Kerr, 1974).

\section{RETORT RESIDUALS}

Aboveground retorting will produce spent shale, retort process water, and retort offgas scrubbing residuals. Of these, spent shale would appear to constitute the largest disposal problem.

\section{Spent Shale}

The quantity of spent shale produced by a $10^{6} \mathrm{bbl} /$ day, mature industry has been estimated at 1-1.8 million MT/day (Hand, 1969). This quantity of shale is sufficient to cover 2.5 square $\mathrm{km}$ to a depth of $75 \mathrm{~cm}$. In comparison to the volumes of shale oil produced it represents approximately 5-6 barrels of spent shale per barrel of shale oil. Disposal of such quantitites of spent shale is a prodigious task.

Anticipated disposal problem areas include: 1) disposal location, 2) aboveground spent shale stabilization, and 3) mitigation of effects of spent shale leachates.

The original mining location is a natural consideration for spent shale disposal. However, spent shale volume is 10 to $25 \%$ greater than its original unmined volume depending on the process used (Cook, 1974b; Pfeffer and Kerr, 1974). The volume increase occurs primarily because of an increase in pore space from the production of fine particles during the mining and grinding processes. Porosities of unmined oil shales are small $(<5-10 \%)$ compared to 
porosities of spent shale. Depending on the amount of compaction, spent shales may have porosities of up to 40\% (Cook 1974b). Thus, even if the original mines could be completely filled with spent shale a considerable portion must be disposed of by other means. However, the possible simultaneous operations of a dawsonite and nahcolite industry may open up additional volumes of underground mines for the subsurface solid waste disposal (Fletcher and Baldwin, 1973). Some of oil shale may be mined from the saturated zone and methods for efficiently replacing the spent shale in these mines are not available (Ert1, 1965; Cook, 1974b). Furthermore, nominal quantities of $\mathrm{Na}$, $\mathrm{Ca}$, and $\mathrm{Mg}$ oxides, which are soluble in water, may be produced by the partial conversion of carbonates and other minerals at the high retorting temperatures of the shale oil extraction processes. Thus, disposal of spent shales in locations close to existing water tables could present a potential source of ground water pollution by dissolution of these metal oxides.

Emplacement of spent shale in canyons near retorting operations is suggested as a supplement or alternative to mine-filling strategies (Hand, 1969; Pfeffer and Kerr, 1974; Cook, 1974a, 1974b; Fletcher and Baldwin, 1973; Heley, 1974; Hutchins et a1., 1971; and Ward and Reinecke, 1972). Serious problems may be generated by surface disposal because stabilized, spent shale is subject to water and wind erosion (Fletcher and Baldwin, 1973). Compaction of shale and establishment of vegetative cover will be required to minimize the erosion of surface disposed spent shale. (Heley, 1974; Cook, 1974a; Fletcher and Baldwin, 1973). Control reservoirs, retaining dams, and water interception systems will be needed to collect runoff from possible summer flash floods and accumulated snow melt (Cook, 1974a). To establish sufficient vegetation on spent shale and leach soluble salts from the shale, addition of fertilizer ( $N$ and probably $P$ ), and irrigation water will be required (Schmehl and McCas1in, 1973, Cook, 1974a). It has been estimated that up to $1.2 \mathrm{~m}$ of water is required to adequately leach spent shale to obtain a suitable plant growth medium (Cook, 1974b). Schmehl and McCaslin (1973) suggested covering the shale with a layer of soil. To assure downward movement of water (to avoid salt transport from the spent shale to the soil) 
both initial leaching of the spent shale and possibly continued additions of supplemental irrigation water may be required (Bloch and Kilburn, 1973).

of the two process types, the DH type would appear to minimize environmental problems associated with ground disposal. Leachate composition is a function of shale composition and the retorting process. The Tosco II process (IH) leaves up to $5 \%$ residual organic carbon (Schmidt-Collerus, 1974). In the DH processes, virtually all of the carbon residue is burned (Pfeffer and Kerr, 1974) minimizing related potential problems such as complexing of trace elements and solubilization of potential carcinogens (Schmidt-Collerus, 1974). However, the DH processes result in the greatest quantity of readily soluble salts. Initial leachates from DH spent shale have been shown to be up to an order of magnitude higher than for the Tosco II process (Ward et al., 1971).

Retort Wastes

Large quantities of water are removed from the oil shale during retorting (up to $1.5 \%$ of the raw shale by weight). Although this waste may contain some inorganic salts, the component most likely to limit its disposal is the soluble and particulate organic matter (Hubbard, 1971; Routson, 1976). Little has been reported on the properties of organics in the retort waste water. The pyrolytic retorting processes can produce a variety of polynuclear aromatic hydrocarbons (PAH's), some of which are known carcinogens (Schmidt-Collerus, 1974). In addition, shale oil contains much higher concentrations of polar heterocyclic components (particularly $\mathrm{N}$ compounds) than do crude oils. The nitrogen content of whole shale oils usually varies between 1 and $2 \%$ by weight, depending on the source and the process used. Jensen et al. (1971) reported oil derived from gas-combustion retorting to contain $1.46 \% \mathrm{~N}$, oils produced by conventional retorting contained between 1.27 and $1.59 \% \mathrm{~N}$, and in situ methodology yielded nitrogen contents of 1.36 to $1.84 \%$. Poulson et a1. (1971) reported that as much as $20 \%$ of the compounds in shale oil naphthas contained nitrogen, with $96 \%$ of these classified as basic, probably consisting largely of pyridine type compounds. Cook et al. (1968) identified 16 pyridine-type and 11 phenolic compounds in shale oil 
naphtha as well as pyroles and benzonitriles. Cook et al. also found evidence of carbonyl, phenolic, and carboxylic compounds in a shale oil heavy gas oil containing about $3.5 \%$ total nitrogen ( $2 \%$ basic nitrogen).

The environmental significance of the presence of large concentrations of polar and heterocyclic components in shale $0 i 1$ is two-fold. As with almost any mixture of organic compounds, a number of compound types are potentially toxic and/or carcinogenic, and the polar characteristics increase their solubility and accommodation in water systems. Retort waste is amenable to treatment by charcoal sorption with eventual destruction of its organic compounds by heating (Hubbard, 1971) thus preventing adverse environmental effects.

Offgas Scrubber Wastes

Offgases from aboveground retorts may be expected to contain environmentally deleterious compounds, but limited data appear in the literature on either the quantities or general composition of these gases. Liquid scrubber treatments of these offgases may be candidates for ground disposal (Pfeffer and Kerr, 1974). Information pertaining to the environmental consequences of this waste disposal is not available.

\section{PREREFINERY WASTES}

Wastes from the prerefinery distillation, coking, hydrogen steam reforming, hydrogenation, and $\mathrm{Cl}$ aus kiln processes will be similar to the wastes produced by these processes in the petroleum industry. Spent heavy metal, catalysts, diatomaceous earth, caustic wash solutions, coke, deactivated carbon, and extracted As are wastes identified in the Tosco II prerefinery processes (BLM, 1975). Heavy metals identified in catalyst wastes include $\mathrm{Zn}$, Co, Mo, $\mathrm{Fe}, \mathrm{Cr}$, Cu. Unidentified proprietory catalysts are also used. For a 50,000 barrel per day Tosco II plant, it is estimated (BLM, 1975) that spent catalyst wastes will average about $708 \mathrm{MT} / \mathrm{yr}$. Additional estimated wastes include approximately $425 \mathrm{MT} / \mathrm{yr}$ of diatomaceous earth, $425 \mathrm{MT} / \mathrm{yr}$ of deactivated carbon, $860 \mathrm{MT} / \mathrm{yr}$ of caustic wash, 300,000 MT/yr of coke, and 95 MT/yr of extracted As. It is proposed (BLM, 1975) that all of the above wastes be mixed into and disposed with spent shale (20 million MT/yr). 
$?$

$-$ 
ANNOTATED BIBLIOGRAPHY

SECTION I

ENVIRONMENTAL ASPECTS OF THE POTENTIAL DISPOSAL

OF OIL SHALE WASTES TO GROUND 


\section{ANNOTATED BIBLIOGRAPHY}

\section{SECTION I: ENVIRONMENTAL ASPECTS OF THE POTENTIAL DISPOSAL OF OIL SHALE WASTES TO GROUND}

\section{$\underline{1976}$}

Bozak, R. E., and M. Garcia, Jr. 1976. Chemistry in oil shales. J. Chem. Ed. 53(3): 154-155.

Review and history of oil shale.

Donovan, R. P., R. M. Felder, and H. H. Rogers. 1976. Vegetative stabilization of mineral waste heaps. PB-252-176. (NTIS)

The report reviews the establishment of vegetative cover as a candidate method for reclaiming mineral ore waste heaps. It begins by describing the location and properties of spoils and tailings from mining and ore beneficiation, and briefly reviews present methods for controlling dust emissions from them. Most of the report develops fundamentals for establishing vegetative cover, and gives a detailed review of case histories of both successful and unsuccessful revegetation. The report also contains a catalog of individual plant species. This mass of information can be used to provide general guidelines for establishing vegetative cover.

Hundemann, A. S. 1976. $0 i 1$ shale mining, processing, uses, and environmental impacts: Citations from the NTIS data base. PS-760319 (NTIS)

Mining, retorting, chemistry, thermal studies, environmental impacts, and policies relating to $0 i 1$ shale research are discussed. A few abstracts deal with the production of synthetic fuels from shale oil and the economics of $0 i 1$ shale operations. (Contains 223 abstracts)

Hundemann, A. S. 1976. 0il shale mining, processing, uses, and environmental impacts: Citations from the Engineering Index data base. PS-760320 (NTIS)

Exploration, mining, retorting, chemistry, thermal studies, environmental impacts, and policies relating to oil shale research are discussed. A few abstracts deal with the production of synthetic fuels from shale oil and the economics of $0 i 1$ shale operations. (Contains 231 abstracts) 
Kilburn, P. D. 1976. Environmental implication of oil-shale development. Environmental Conservation 3(2): 101-115.

Certain areas of the Piceance Creek Basin are important, not only for their beauty and other amenities but also for their unusual ecosystems. Stoecker (1974) has suggested maintaining one of the larger boxcanyons in the southern portion as a nature reserve. Knutson and Boardman (1973) have suggested preserving a 'green belt' to involve the magnificent bluffs adjacent to the Colorado River. Preservation of the Cathedral Bluffs running north and south in the western portion has also been suggested. It is clear that a movement is growing to provide a system of natural areas throughout the Basin. Such a system would maintain important examples of representative vegetation types, wildlife habitat, geological and archaeological features, and other areas of particular ecological interest. This preserve system would maintain natural (or semi-natural) areas both as ecological baselines and as nuclei for obtaining biological 'seed' for rehabilitation of disturbed areas. A study to delineate suitable areas that could be included in such a system is surely needed.

Man is viewing vast resources in the Piceance Creek Basin, which probably has the world's largest known hydrocarbon deposit, and his use thereof seems inevitable. The magnitude of the deposit certainly demands a major planning effort. One can even speculate into the future, to visualize a concerted or systems approach to obtaining and processing this resource.

Nevertheless, until commercial activity begins and monitoring procures actual data, predictions will remain speculative. Operation of a few commercial plants, mines, and rehabilitation activities, is needed in order that precise predictions can be made for better delineation and quantification of the environmental impacts of a major shale-oil industry.

Novak, A. 1976. 011 shale resources: How much? Shale County 2(2): 46. Geology comes up with an answer in the trillions of barrels. Recoverable may only be a small fraction of total (est. at 1/3).

Routson, R. C. 1976a. 2nd Quarterly Report on "Development of a chemical reactions, stability, and transport model of oil shale process wastes in soils." Contract TD 0747 between ERDA and EPA.

Retort process water was characterized as to its content of nonvolatile residual organic material gravimetrically by heating to $60^{\circ} \mathrm{C}$ for 24 hours. It was found to contain $35.8 \mathrm{~g} / 1$ of material. Only $0.9 \mathrm{~g} / 1$ of this material was filterable through $0.45 \mu$ and $0.01 \mu$ membrane filters. Less than $0.4 \mathrm{~g} / 1$ of material was noncombustible demonstrating that the bulk of material was organic. Benzene extracted only $0.4 \mathrm{~g} / 1$ of material demonstrating that the material was either very polar or microparticulate. The material was subjected to TLC techniques using a very polar solvent and a 
cellulose binder. Essentially $100 \%$ of the material moved with solvent front. From the above series of experiments, it was concluded that the organic material is 1) in extremely high solution concentration; 2) in true solution; 3) very polar and of reasonably low molecular weight; and 4 ) its resolution on TLC plates will probably require mixtures of more nonpolar compounds than the very polar solvents used in the above experiments.

A technique was perfected to measure the sorption of organic compounds on soils and spent shale. In the developmental experiments pyridine was used as the sorbing compound. The fraction sorbed decreased from $49 \%$ to $24 \%$ as the equilibrium solution concentration increased from 2-35 mg/1. This is suggestive of a Langmuir isotherm type of sorption.

Routson, R. C. 1976b. 3rd Quarterly Report on "Development of chemical reactions, stability, and transport model of oil-shale process wastes in soil." Contract TD 0747 between ERDA and EPA.

Characterization of the "soluble" organic in a retort process water from BOM simulated in situ report and TCL showed the material to be: 1) $\mathrm{V}$. polar; 2) in true solution; and 3 ) would require a polar solvent for resolution on TLC plates. Use of a mixture of polar solvents resulted in resolution of "soluble" organic into four spots. As determined by bromcresol green indicator, three of the spots were acidic and the fourth was basic. Total "soluble" organic and volatile organic were measured. Total "soluble" organic was found to be $40 \mathrm{~g} / 1$ and volatile organics $5 \mathrm{~g} / 1$.

Further work developed a batch-sorption technique using pyridine. Sorption of collidine by the technique on a soil was found to fit the Langmuir sorption isotherm and the Langmuir bonding and sorption maximum parameters were determined for the soil.

Routson, R. C. 1976c. 4th Quarterly Report on "Development of chemical reactions, stability, and transport model of oil-shale process wastes in soil." Contract TD 0747 between ERDA and EPA.

A retort waste water from the Bureau of Mines, Laramine, WY simulated in situ oil shale retort was characterized for its concentration and speciation of $\mathrm{As}$, Se, and $\mathrm{Sb}$. It was found that total As and Se concentration is 80 and 17 times the P.H.S. standard for drinking waters 0.05 and 0.01 $\mu \mathrm{g} / \mathrm{ml}$ respectively. Thus, $\mathrm{As}$, and $\mathrm{Se}$ will be added to $\mathrm{B}, \mathrm{Mo}, \mathrm{Cr}$, and $\mathrm{Cu}$ as initial elements which will be monitored. In addition, methylated As compounds were undetected at the $0.010 \mu \mathrm{g} / \mathrm{ml}$ level. Duplicate samples of Sohxlet extracts of a spent shale from the Bureau of Mines, Laramie, WY, simulated in situ retort was characterized for its concentration and speciation of As, Se, and Sb. It was found that As and Se were below P.H.S. standards, and although no P.H.S. standard exists for $S b$ it is probably near or below any proposed standard. In addition, methylated As compounds were undetected at the $0.01 \mu \mathrm{g} / \mathrm{ml} 1 \mathrm{evel}$. 
A retort waste water and Sohxlet extract of spent shale were characterized as to their concentration of S, N, C, F, and halides. This data confirm the high solubility of organic $N, C$, and $S$ previously reported and demonstrates that soluble organics are much more soluble than their crude petroleum counterparts.

The PERCOL model, which is the basic model that was broadened in this program, was expanded to include the inorganic complexes $\mathrm{CaCO}_{3}{ }^{\circ}, \mathrm{CaSO}_{4}{ }^{\circ}$, $\mathrm{MgCO}_{3}{ }^{\circ}, \mathrm{MgSO}_{4}{ }^{\circ}, \mathrm{NaHCO}_{3}{ }^{\circ}, \mathrm{CaHCO}_{3}+, \mathrm{MgHCO}_{3}+, \mathrm{NaSO}_{4}, \mathrm{NaCO}_{3}, \mathrm{KSO}_{4}, \mathrm{NH}_{4} \mathrm{SO}_{4}$, $\mathrm{MgF+}$, and $\mathrm{CaF}+$. Precipitates now considered in the PERCOL model include $\mathrm{CaCO}_{3}, \mathrm{CaF}_{2}, \mathrm{CaSO}_{4}, \mathrm{H}_{2} \mathrm{O}, \mathrm{MgCO}_{3}, \mathrm{MgSO}_{4}, \mathrm{MgF}_{2}, \mathrm{SrCO}_{3}, \mathrm{SrF}_{2}$, and $\mathrm{SrSO}_{4}$. The results of the changes were verified using known solution data.

Yen, T. F. (ed.). 1976. Science and Technology of 0 il Shale. Ann Arbor Science Publ. Inc. Ann Arbor, MI, 226.

Papers:

1. Yen, T. F. 0il shales of the U.S. - a review.

2. Meyer, W. C. and T. F. Yen - Modification of the mineral matrix by bioleaching.

3. Miknis, F. P., A. W. Decora, and G. L. Cook. Pulsed NMR examination of oil-shales-estimation of potential oil yield.

4. Whitcombe, J. A. and R. G. Vawter. The Tosco II shale process.

5. Young, D. K., S. Shih, and T. F. Yen. Mixed oxidation of bioleached oil shale.

6. Crew, R. T., III. Operations and environmental considerations, Occidental Petroleum Corporation's in situ operations.

7. Wen, E. S. and T. F. Yen. Electrolytic oxidation and reduction of oil shale.

8. Jacobson, I. A., Jr., A. W. Decora, and G. L. Cook. Retorting indexes for oil shale pyrolyses from ethylene/ethane ratios of product gases.

9. Schmidt-Collerus, J. J., F. Bonomo, K. Gala, and L. Leffler. Polycondensed aromatic compounds (PCA) and carcinogens in the shale ash of carbonaceous spent shale from retorting oil shale.

10. Kim, K. E., J. A. Higa, and T. F. Yen. Sulfur recovery by desulfovibrio in a biochemical method of oil shale production.

11. Silver, H. F., N. H. Wang, H. B. Jensen and R. E. Poulson. A comparison of shale gas oil denitrification reactions over Co-Mo and $\mathrm{Ni}-\mathrm{W}$ catalysts. 
12. Findley, J. E., M. D. Appleman, and T. F. Yen. Microbial degradation of oil shale.

13. Schmidt-Collerus, J. J., and C. H. Prien. Investigations of the hydrocarbon structure of kerogen from oil shale of the Green River Formation.

14. Yen, T. F. Structural investigations on Green River oil shale.

15. Moussavi, M. and T. F. Yen. Environmental improvements by oil shale leaching.

Yen, T. F. 1976. $0 i 1$ shales of the United States. In: T. F. Yen (ed.) Science and Technology of 0il Shale. pp. 1-17.

General Review.

Feasibility of extraction and utilization is discussed using comparisons with conventional fuel costs. Table shows production outlay estimates at different price levels. (NTIS)

$\underline{1975}$

Anon. 1975a. Voice of the people: Why the Colony Suspension? Shale Country 1 (1): 18-19.

Colony's announcement that it was suspending plans because of a threepronged dilemma--double-digit inflation, tight money and lack of a national energy policy--sent shock waves through shale country. Many old-timers, remembering previous oil-shale "booms", took the announcement as proof that, once again, the promised shale development was going bust. Some observers wondered aloud if the company wasn't simply trying to wrangle a favorable shale policy from the government. And others simply asked, "What next for oil shale?"

A11 of these responses are natural and logical. But, so was Colony's decision, as anyone familiar with tight dollars, government indecision and rising-out-of-sight prices can understand. For further background, the following series of questions and answers details the reasons behind the surprise announcement. (Responses were provided by Colony Officials.)

Anon. 1975b. 0il shale suffers setback. Min. Eng. (NY), 27(5): 53-54.

If world oil prices stabilize at $\$ 11 / \mathrm{bbl}$, if the US decides on the "accelerated supply" case for domestic fuel resources, if investment capital is available, if environmentalists' demands become reasonable, if land withdrawals are halted, if government grants generous depletion allowances and 
fast depreciation write-offs, and if many other "iffy" conditions are met--then shale oil production may reach the l-million-bpd level by 1985, according to the Project Independence Report. In the "base case" scenario, oil shale production would be, at best, about 250,000 pbd at $\$ 11$ prices, and "much lower if expectations for $\$ 7$ oil prices prevail."

In this regard, the FEA study reflects the conclusion reached by companies engaged in oil shale development work. Thus, except for some new technological breakthrough in mining, the birth and growth of the US oil shale industry will occur only if oil prices stablize at about $\$ 11 / \mathrm{bbl}$.

$0 i l$ shale's initial capital requirements are very high--e.g., $\$ 12,000$ to $\$ 15,000$ per daily barrel, as compared to about $\$ 1000$ to find and develop conventional crude oil in the Middle East, and $\$ 5000-$ to- $\$ 10,000 / \mathrm{bb} 1$ for the cost of the Alaska's North Slope oil (which includes the cost of the pipeline). The operating costs are also much greater than those of conventional oil and gas operations. Understandably, corporations are reluctant to risk the necessary large investments without assurance of price stability. If world oil prices should suddenly and intentionally be lowered, oil shale investors would take a multi-billion-dollar financial bath.

Battelle Pacific Northwest Laboratories Staff. 1975. "0il shale: PNL Plan for Environmental and Health Research."

Documents the need for environmental and health research related to shale 0 il manufacturing and describes the research to be conducted in the areas of source characterization, transport, environmental and health effects and assessment. Particular attention has been given to the necessary interactions between disciplinary areas required for a sound program. PNL presents specific recommendations for implementing a coordinated national program for shale $0 i l$ environmental research.

Bowden, C. 1975. The impact of energy development on water resources in arid lands. PB-240-008. (NTIS)

Water is basic to energy conversion systems, natural and man-made. Consequences of energy extraction and conversion in arid lands where water is scarce are explored. The historical past is utilized as a record for casting modern development plans into perspective; the worldwide growth in energy consumption rates is considered as the motive force behind many current energy projects in arid lands. Energy sources (coal, oil, gas, oil shale, solar energy, alternative energy sources, fission, fusion, and geothermal) are reviewed in terms of their consequences on the air, land, water, and inhabitants of such regions. Two rivers, the Colorado and the Missouri, provide small-scale models of the rewards and hazards of heavily exploiting water-short areas. In both instances, energy development plans, as now proposed, will seriously deplete the water supply, alter the quality of the water, land, and air, and increase the human population. (NTIS) 
Burke, H. D., (Coord). 1975. Wildlife and oil shale: a problem analysis and research program. 1: PB-250-521. (NTIS)

This program analysis and research program considers the natural and social environment of the $0 i 1$ Shale Region of northwestern Colorado, northeastern Utah, and southwestern Wyoming. The purpose was to examine and evaluate the probable consequences of a developing oil shale industry upon the environment, to devise research studies that would evaluate environmental and social changes, and to assist in avoiding or mitigating undesirable changes, particularly as they pertain to wildlife. The analysis was done by a group of nineteen highly qualified scientists with extensive experience in the region or related areas. These scientists reviewed problems and designed appropriate studies. Through screening by sets of "key questions", the original 162 studies submitted were reduced to 128. Ten studies were selected from this number as "Priority Studies" recommended for immediate implementation. This analysis stresses the need for quality control throughout all phases of a research program and, as a means of introducing quality control into this analysis, this report was submitted for review to an "Overview Committee" of three senior scientists recognized as authorities in their fields and in the Rocky Mountain Region.

Burger, E. D., D. J. Curtin, G. A. Myers, and D. K. Wunderlich. 1975. Prerefining of shale oil. Am. Chem. Soc., Div. Pet. Chem. Preprint 20(4): 764-775.

Prerefining involves those process steps which are performed on a raw oil to make it tractable for use as a major portion of the feed to refineries designed to process conventional crudes. A prerefining flow sheet usually, therefore, includes distillation, solids separation (perhaps by coking), and hydrogenation-hydrocracking for chemical stabilization, molecular weight reduction, and hetero-atom removal. A discussion is presented of the properties of raw shale oil and their relationship to prerefining requirements. 26 refs. (NTIS)

Carlton, K. 1975. Digging into shale's rocky past. Shale Country 1(10): 20.

History of oil shale and shale oil in the Rocky Mountains.

Commerce Technical Advisory Board Staff. 1975. Review of project independence b7ueprint - panel sub-committee reports on FEA-interagency task forces.

COM-75-10500. (NTIS)

Data, assumptions, and background information used to develop Project Independence Blueprint are discussed. Topic areas covered include: Energy demand/conservation; Coal; 0i1; Natural gas; Nuclear energy; Future energy sources; $0 i 1$ shale; Transportation; Water and environment; Human resources; Finance; and Materials, equipment, and construction. (NTIS) 
Crookston, R. B. 1975. Mining oil shale. SAE Preprint 750724 meeting of Society of Automotive Engineers. Aug. 11-14, 1975.

Mining oil shale in Colorado for the first commercial oil shale venture has been optimized by Colony in terms of the best mining method and equipment available today. A discussion of the progress toward optimization of mining by Colony and others and of the nature and extent of oil shale in Colorado and Utah leads into a recitation of the potential for improvements. (NTIS)

DiSante, E. 1975. A jook at oil shale-What's it all about. Shale Country $1(1): 4-7$.

Basic review.

Doyle, W. S. 1975. Strip mining of coal environmental solutions. Noyes Data Corp., Park Ridge, NJ. 352 pp. Pollution Tech. Rev. No. 27.

Late in 1974 the Office of Research and Development of the U.S. Environmental Protection Agency made the statistically well founded projection that for the remainder of the 20th century surface-mined coal will have to account for over $50 \%$ of our nation's production of this fuel.

Strip mining can be done responsibly without permanent damage to land and water. Technology exists for effective reclamation of mined lands, and such reclamation is being performed in some areas. Authorities emphasize the importance of planned premining (fully discussed in this book) and point out that reclamation is less costly and more effective when integrated with the mining operation.

This book, based on 19 government reports issued from 1967 through 1974, describes surface mining of coal, land use and methods, land reclamation technology plus sediment and erosion control. Acid mine drainage, its sources, prevention and correction, as well as the mechanism of reclaiming acid strip mine lakes are discussed. Specific studies on revegetation, use of spoil amendments etc. are included. A whole chapter is devoted to West Germany's approach to the problem of strip-mined lands. The final two chapters are devoted to costs, economics, and financing.

A partial and condensed table of contents follows here. Chapter headings are given, followed by examples of important subtitles.

1. LAND USE METHODS

Reclamation Survey Figures

Impact on the Environment

Area Mining

Contour Mining 
2. LAND RECLAMATION METHODS

Blasting Control

Backfilling \& Grading

Revegetation Problems \& Methods

Spoil Amendments

3. SEDIMENT \& EROSION CONTROL

Sediment Control Basins

Pit Drainage

Bench Drainage

Coal Haul Roads

4. REVEGETATION STUDIES

Three Pennsylvania Sites

Effect of Lime \& Fertilizers

Relative Hardiness of 14 Species of Trees \& Shrubs

Results on Anthracite Strip Mine Spoils

Vegetative Analysis of 81 Strip Mine Areas

5. SPOIL AMENDMENT STUDIES

How to Use Municipal Sewage Sludge and Effluents on Strip Mine Soils

Reclamation of Acid Spoil with Fly Ash

Means, Materials \& Methods

6. ACID MINE DRAINAGE (AMD)

Prevention of Acid Formation

Corrective Measures

Water Infiltration

Drainage Control

7. EROSION CONTROL AND WATER QUALITY

Sulfur Distribution in the Overburden Material

Lock Weathering

Interactions with $\mathrm{Plant}$ Covers

8. EFFECTS OF MINE DRAINAGE

Lysimeter Study

Effects on Lake Biology

Patterns for Stripland Utilization

9. RECOVERY OF ACID STRIP MINE LAKES

Survey of Investigations

Discussions \& References

10. AREA RECLAMATION PROJECTS

Grundy Demonstration Project

Spoil Relocation

Topsoil Placement

11. RECLAMATION OF SURFACE-MINED LAND IN WEST GERMANY

Comparative Rehabilitation Data 
12. RECLAMATION COSTS

Strip Mining Economics

"Pre-Law" Lands

Funding

13. AMD CONTROL PROGRAM FOR A SMALL COMPANY

Long Run Adjustments

Gallegos, E. J. 1975. Terpane-sterane release from kerogen by pyrolys is gas chromatography-mass spectrometry. Anal. Chem. 47(9): 1524-1528.

Analysis by pyrolysis gas chromatography-mass spectrometry (GC-MS) and GC-MS of the pyrolyzate of kerogen from Green River shale showed pyrolytic release of many identifiable terpanes and steranes, some of which are known to be present in the solvent extractable oil from this shale. These included, among others, gammacerane, 17- $\alpha(H)$ hopane, and the 5- $\alpha$ and $5-\beta C_{27}, C_{28}$, and $C_{29}$ steranes, cholestane, ergostane, and stigmastane, respectively.

Gary, J. H. (ed.). 1975. 0il shale symposium, 8th, proceedings, 1975. Colo. Sch. Mines Quart. 70: 1-313.

Nineteen papers by various authors are presented. The topics discussed are: Energy input-output in shale oil, direct combustion retorting process, in situ process, energy self-sufficiency in 1985, resource appraisal, Dawsonite geochemistry, alumina from dawsonite oil shales, thermo- oxidizing pyrolysis, Lurgi-Ruhrgas process, accelerated in situ program of the U.S., R\&D on rubble in situ extraction (RISE), simulated in situ retorting, excess heat generation, thermal behavior of oil shale, retorting of rubble: a model of heat transfer and product formation in oil shale particles, and a mathematical model of an $0 i 1$ shale retort. (NTIS)

Globe, S., and R. A. Craig. 1975. A review of the project independence report submitted to office of Energy Research and Development, NSF, January 10, 1975.

This report reviews and evaluates the Project Independence Report (PIR) issued in November 1974 by the Federal Energy Administration. The review includes comments on the PIR as a whole, and also provides detailed critiques of the various topics, strategies, and scenarios and they are discussed by the PIR, including energy and fuel supplies, conservation and demand management, environmental assessment, economic and social impacts, international assessment, and the analytical approach. Special attention is given to the policy implications of the PIR strategies. (NTIS)

Grimmer, G, and H. Böhnke. 1975. Profile analysis of polycyclic aromatic hydrocarbons and metal content in sediment layers of a lake. Cancer Letters 1: 75-84. 
The Question is investigated whether polycyclic aromatic hydrocarbons (PAH) in the annual sediment layers of a lake mainly result from air dust pollution. Sample layers taken from drilling cores going back to 1915 show no significant differences at the forest shore (no buildings) during this period. In contrast, samples taken from a built-up area of the shore (with a highway and a main railway line) show today 5 times the amount of PAH compared with 1915. The same trend is observed in the content of $\mathrm{Zn}$, whereas $\mathrm{Pb}, \mathrm{Fe}, \mathrm{Cr}, \mathrm{Ni}, \mathrm{Cu}$ and $\mathrm{Mn}$ levels are constant.

Identification or characterization of PAH was accomplished by comparison of the retention times and mass spectrometry of authentic compounds. Sixty-four PAH are described. The results indicate that the burden of carcinogenic PAH air pollutants has increased 5-fold from 1915-1970.

Haas, F. C. 1975. Alumina recovery from oil shale residue. U.S. Patent $3,859,413$.

An essentially silica-free alumina product is obtained from dawsonitebearing oil shale by a process which involves rapidly wetting and leaching the retorted residue at about $5^{\circ} \mathrm{C}$ to about $40^{\circ} \mathrm{C}$, with a dilute alkaline leach liquor followed by ppt. of the extracted alumina directly from the leach liquor at $\mathrm{ca} .60^{\circ} \mathrm{C}$ to $\mathrm{ca} .75^{\circ} \mathrm{C}$ in the presence of alumina seed.

Hoskins, W. N., F. D. Wright, R. L. Tobie, J. B. Bills, R. P. Upadhyay, and C. B. Sandberg. 1975. A technical and economic study of candidate underground mining systems for deep, thick oil shale deposits. Phase I. NTIS PB-249-884.

Contractor investigated and evaluated all potentially feasible methods for large-scale mining of the thick oil shale deposits in the deeper central part of the Piceance Creek Basin of Northwestern Colorado. Technical and economic data were obtained, preliminary layouts and designs were prepared, and pertinent operating features and cost data were anaylzed and evaluated. The relative merits of each mining method were defined and the following candidates were selected as most promising for detailed design and analysis under Phase II of the contract: Chamber and pillar mining with spent shale backfill; (2) Sublevel stopping with spent shale backfi11; (3) Sublevel stopping with full subsidence; and (4) Block caving mining using LHD's.

Hughes, E. E., P. A. Buder, C. V. Fojo, R. G. Murray, and R. K. White. 1975. 0 il shale air pollution control. PB-242-858. (NTIS)

The study evaluates the air pollution potential of emissions of particulates, sulfur dioxide, oxides of nitrogen, and hydrocarbons from anticipated development of an oil shale industry. The analysis is based primarily on the published description of a TOSCO II retorting process as 
planned for commercial use by the Colony Development Operation. The technology, processess, plans, projections, and environmental impacts of oil shale development are reviewed. The results of dispersion model calculations of concentrations of pollutants in ambient air near oil shale plants employing TOSCO II and in situ processes are presented. These calculations for the TOSCO II plant assume that best available controls are applied to the process planned by Colony. Requirements for additional control are estimated by comparing calculated ambient air quality with standards. Options for supplying the additional control indicated for particulates and sulfur dioxide are identified. (NTIS)

Johnson, H. R. 1975. Potential role of shale oil prospects and constraints. Mining Yearbook 1975: 65-71. Colo. Mining Assn.

An Interagency 0il Shale Task Force headed by the Department of the Interior has examined the prospects for extending oil shale production to meet the objectives of Project Independence. That analysis shows that the rate at which oil shale can be developed depends upon a number of interrelated factors. Initially, it will depend on the availability of venture capital that can expect only a minimum acceptable rate of return. However, as the industry matures, profitability should increase and other factors will become more important than venture capital. Eventually a point will be reached, beyond which no matter how profitable the operations might be, expansion will not be possible due to other noneconomic limitations. Under Business as Usual, oil shale development might reach 250,000 barrels a day by 1985. However, certain government actions can be taken to stimulate development. In this event, production could reach the 1 million barrels per day level by 1985. This paper explores the prospects for future oil shale production and discusses the constraints inherent in expanding such production.

Kalter, R. J., and W. E. Tyner. 1975. An analysis of federal leasing policy for oil shale 1ands. PB-244-113. (NTIS)

A historical review and critque of federal agency procedures for leasing oil shale resources on public lands is provided. On the basis of this review and critique, issues of public policy are identified and possible alternative courses of action with respect to such issues evaluated. Major emphasis is placed upon the governmental revenue and oil production aspects of alternative leasing strategies and schedules. In this regard, both the type of leasing system and the provisions of the lease contract, itself, are evaluated. In addition, potential constraints on the achievement of specified leasing objectives are identified and attempts made to determine their implications for such objectives. Finally, possible requirements for market intervention by the public sector to meet stipulated national objectives involving energy supply are explored and alternative courses of action identified and evaluated. (NTIS) 
Leach, H. J. 1975. Analysis of methods for underground mining of oil shale. Mining Congress J. 61(5): 33-34.

The possibility of producing oil from domestic oil shales has intrigued many people for over a century. It was accomplished on a crude basis in the 1850s in Ohio and Pennsylvania but the discovery of 011 in 1859 shut the budding industry down. Fears of an oil shortage following World War I led to a staking rush in Colorado and Utah in the 1916-20 period and to much experimental retorting activity in the 1920s but large oil discoveries with consequent low prices stopped that boom. Interest rose again following World War II with experimental mining and retorting conducted by the U.S. Bureau of Mines and Union $0 i 1$ Co., but these efforts also collapsed, primarily because shale oil could not compete economically with crude $0 i 1$.

Lewis, A. E. 1975. The outlook for shale oil. In: Penner, S. S. (ed.) Identification of research and development priorities and of costing problems associated with implementation of in situ recovery of shale oi1. PB-246-278, p. 218.

The extent to which oil from domestic oil shale will provide energy in the future depends as much on national and regional political decisions, as it does on technical or economic issues. Technology available to industry in this decade can be used to ensure a modest supply of oil from oil shale at present prices and with a total reserve of about 54 billion barrels of $0 i 1$, if some government land is made available and environmental requirements are defined. In addition, we have the capability of developing technology within this decade to produce oil in large enough quantity and at low enough cost to exert a major influence on the national and international oil market.

In situ processes and/or massive open-pit technology would open up a much larger resource (200-800 billion barrels) within a small area (600 mi2) of Colorado. Development of this technology is beyond the capability of industry alone and will require a definition of the role of government and industry in the planning, management, production, and ownership of the resource.

Jackson, L. P., R. E. Poulson, T. J. Spedding, T. E. Phillips, and H. B. Jensen. 1975. Characteristics and possible roles of various waters significant to in situ oil shale processing. Colo. Sch. of Mines Quart. 70(3):105-134.

An in situ $0 i 1$ shale development program requires consideration of water produced with oil in retorting oil shale and of natural waters significant to oil shale processing. These waters may be heavily laden with organic, inorganic, or both types of constituents and must be considered for feasibility of use, storage or disposal in environmentally acceptable ways. Analysis of such waters are presented. Compositions are shown for a variety of simulated in situ retort-produced waters. Compositions of 
natural underground waters occuring in potential in situ development areas in the Upper Green River Basin of southwestern Wyoming are presented. Retort-produced waters contain as much as 2 percent organic and 5 percent inorganic constituents and may be produced in volumes in excess of that of the oil. Natural waters of significance may contain over 5 percent inorganic and 5 percent organic components.

Jackson, L. P., and A. W. Decora. 1975. Kerogen constituents: reduced chlorophyllin as a model for the precursors of nitrogenous compounds in shale 011. Am. Chem. Soc., Div. Fuel Chem. Preprint 20(2): 147-153.

In evaluating and developing the resource potential of the nation's vast oil-shale reserves, the U.S. Bureau of Mines has been conducting research in the origins and chemistry of shale oil. As part of this work, the role of plant pigments and their decomposition products as possible precursors of the nitrogenous compounds found in shale oil was investigated. The reduction and pyrolys is of a commercially available plant pigment extract, chlorophyliin, is described. The amounts of bases formed and their boiling-range distribution are related to the hydrogen content of the starting materials. Mass spectral studies are given which show that many of the same types of bases are found in the pyrolsate and in an in situ light distillate. These results indicate that reduced chlorophyllin may be used as a model for the nitrogen containing constituents in kerogen. 10 refs. (NTIS)

Kilker, C. 1975. Lilies in the shale fields. Shale Country 1(10): 12-14. A description Colony's revegetation efforts.

Ligon, D. R. 1975. The outlook for oil shale in energy and economic program. Colo. Mining Association, Denver. Mining Yearbook. pp. 72-74.

With adequate government support, production of oil from shale could reach 400,000 to 500,000 barrels per day by 1985 .

Positive evidence of the Administration's concern that oil shale development proceed in a timely fashion towards commercializations provided by discussing some of the major incentive options being analyzed by the government. These options are the result of the second phase of a study being conducted by the National Science Foundation and the Federal Energy Administration.

The most encouraging and concrete news for shale oil is contained in the President's new budget... the Administration is clearly putting more emphasis on research and development of the so-called "exotic" fuels for the future. 
It is clearly recognized that many of the problems and uncertainites associated with oil shale processing have not been solved, Ligon said. It is not believed any are so great that they cannot be solved.

Marsha11, P. W. 1975. Colony Development Operation oil shale: mining and recovery of oil. SAE Preprint 750580 meeting of Society of Automotive Engineers. Apri1 15-16, 1975.

The paper begins with a brief history of Colony Development Operation, followed by an overview of the planned commercial mine and plant complex which includes artists' conceptions of the designed layout. The commercial operation, two-bench, room-and-pillar mining system design is described in detail. The mining cycle of drilling, blasting, loading, hauling, scaling, and roof bolting is discussed as well as the mobile mining equipment which is being designed and will be utilized. Some of the detailed Colony pilot mine engineering testing programs are then introduced, and their effect on the commercial mining of oil shale is enumerated. (NTIS)

Morandi, J. R., and R. F. Poulson. 1975. Nitrogen types in light distillates from aboveground and in situ combustion produced shale oils. Amer. Chem. Soc., Div. Fuel Chem. Preprint 20(2): 162-174.

Chemical types of nitrogen in light distillate (nominal $400^{\circ}-600^{\circ} \mathrm{F}$ boiling range) fractions from combustion-retorting crude shale oils are compared for an aboveground $0 i 1$ and an in situ oil. In each case the light distil1 ate fraction contained 1.34 percent total nitrogen. 85 percent or more of this nitrogen was titratable as bases. The aboveground light distillate was 15 percent of the crude shale oil while the in situ light distillate was about 50 percent of the crude shale oil. The nitrogen in the oils was classified by its separability in the following scheme as well as subsequent chemical-type analyses. The distillates were separated into acid, base, neutral-nitrogen, and hydrocarbon fractions from columns by graded solvent desorption. Columns in order were anion-exchange resin, and ferric chloride on Attapulgus clay. The distillates and fractions were analyzed for the following chemical types: Weak bases (pKa +8 to +2 ), very weak bases (pKa +2 to 2 ), neutral compounds (pKa $<-2$ ) pyrrolic $\mathrm{N}-\mathrm{H}, \alpha$ - or $\beta$-unsubstituted pyrrolic nitrogen, total nitrogen, phenolic $\mathrm{OH}$, and carboxylic $\mathrm{OH}$. About half of the total nitrogen in each of the distillates was desorbed in the strongest base-type fractions (typically pyridine-type nitrogen). The remainder of the nitrogen was distributed in base, acid, neutral, and hydrocarbon fractions. The above-ground distillate showed evidence of its greater oxygen content mainly in having weaker bases in general than the in situ distillate. In addition, one-fifth of its acids were carboxylic type with the balance phenolic. The in situ distillate was almost completely phenolic in its acid fractions. These oxygenated materials represent only about onethird of the aboveground distillate oxygen and three-fourths of the in 
situ distillate oxygen. The aboveground distillate had approximately equal amounts of pyrroles and indoles and in the in situ distillate, pyrrolic nitrogen was almost completely indole type. Approximately twothirds of the oxygen in the aboveground retorted $0 i 1$ and one-fourth in the in situ retorted oil were unaccounted for as oxygen acids.

Paxton, J. 1975. Superiors's oil shale process: trying to live up to its name. Shale Country 1(10): 7-9.

Describes Superior's process and problems.

Penner, S. S. 1975. Identification of Research and Development Priorities and of Costing Problems Associated with Implementation of In Situ Recovery of Shale 0i1. PB-246-278. (NTIS)

A workshop on in situ recovery of shale oil was held at the University of California, San Diego, during September 1974. The purpose of the workshop was to identify the critical problem areas impeding the practical development of in situ shale oil recovery techniques. This document is a report on the proceedings of that workshop. It emphasizes the special problems relating to the development of in situ technology and identifies the critical research, development, and costing areas, rather than reiterating the well known facts of the enormous potential resources and the social and political costs of exploiting those resources. Included here are reports from the Fracture Panel, from the Retorting Panel, from the Environmental Impact Panel, and from the Economics Panel. Additionally, there are nine invited papers, lectures presented at the workshop, and numerous appendices and comments.

Persse, F. H. 1975. Strip-mining techniques to minimize environmental damage in the upper Missouri River basin states. Bur. Mines Infor. Circ. IC 8685 .

Escalating energy requirements, substantial increases in production from strippable coal and lignite deposits in eastern Montana, western North Dakota, and northeastern Wyoming already have occurred, and further expansions are expected to continue at least until the year 2000. Such production, attributable largely to demand for low-sulfur coal, must be accomplished with a minimum of adverse effects on the environment. Information of geology, climate, and current land use in the Upper Missouri River basin is presented as a guideline to what operators may expect during and after mining. Proven methods of protecting the air and water from pollution and of restoring mined 1 and for other uses are described by the Bureau of Mines. In addition, untried methods of 1 and reclamation, some with equipment yet to be manufactured, are discussed as means of maintaining high aesthetic values in the basin. Costs incurred to protect the environment are a legitimate part of the production cost 
and must be borne by the ultimate consumer. Unit production costs are less for the thick coal and lignite deposits of the basin than for the thinner but higher new coal deposits of the eastern and midwestern United States. Precise comparisons of environmental protection costs between mines in such disparate areas connot be made primarily because of differences in physical conditions, accounting procedures, personal references, and other variables.

Poulson, R. E., and H. B. Jensen, 1975. Environmental effects of in situ recovery of shale oil. In: Penner, S. S. (ed.) Identification of Research and Development Priorities and of Costing Problems Associated with Implementation of in situ Recovery of Shale 0i1. PB-246-278, pp. 251-263. (NTIS)

This paper discusses the potential effects of in situ shale-oil recovery on environmental concerns relative to those which have been published for aboveground recovery. The salient environmental features of the in situ approach are dicussed with respect to air, land, water, and socioeconomic elements. Applicability of in situ techniques is shown to be quite site specific. Where applicable in situ recovery could minimize mining activity, particulate emissions, water supply requirements, and land requirements. Gaseous emissions could be a similar problem in either in situ or aboveground processing on a large scale. The need for managing large volumes of water can occur in either approach. Internal-combustion in situ retorting may produce in itself large volumes of organic and mineral laden water for recovery or disposal. Similar numbers of people would probably be employed in either approach. Not enough is known about in situ methods or details of the resource in its matrix to make realistic cost estimates of general applicability.

Petzrick, P. A. 1975. $0 i 1$ shale-an ace in the hole for national security. Shale Country, 1(10): 18-20.

Distortions of world map in proportion to a country's energy resources.

Petzrick, P. A. 1975. Project independence, national security, and the environment. Naval Engineers J. 87: 115-119.

A comparison of the relative power of the United States and the balance of the world is made: first, on the basis of petroleum alone and then based on the addition of petroleum-related fossil fuels, coal, and $0 i 1$ shale, to illustrate the strength that might be achieved through diversification. It is proposed to optimize the value of $0 i 1$ shale deposits by combining their hydrocarbon with petroleum. It is suggested that such optimization might make numerous other marginal natural resources competitive with the cheap, convenient sources which have become the subject 
of international friction. The cost and possible consequences of national energy independence are cited, supporting the need for world cooperation. The environmental problem is bracketed by comparing the burning of coal in the eastern United States with delays in completion of the Alaskan pipeline. 14 refs. (NTIS)

Robinson, W. E., and G. L. Cook. 1975. Compositional variations of organic material from Green River oil shale-WOSCO EX-1 core (Utah). U.S. Bur. Mines RI 8017. 40 pp.

Differences in the composition of chemical structure of the organic material in samples of Uinta Basin (Utah) oil shale were studied relative to stratigraphic position within the Green River Formation. This involved a systematic study of the soluble organic material and the insoluble organic material (kerogen) present in the samples. Emphas is was placed upon the distribution of the alkanes (normal and isoprenoid compounds) in the soluble extracts and upon the aromaticity of the kerogen. Significant differences exist in the chemical composition of the organic material from various strata within the Uinta Basin, some of which were related to burial depth but most were related to source material variations, environmental differences, or other factors. The Uinta Bas in samples differed significantly from Piceance Creek Basin and Green River Bas in samples in the large amount of soluble extract they contained.

Rothman, A. J. 1975. Environmental impacts of in situ shale oil development. Univ. Calif. Sanitary Engineering News Quart. 25(4): 1-2.

Little is presently known about the potential side effects of this type of processing. Water requirements are large averaging approximately two barrels of water per barrel of oil processed. The deposits occur in a water-short area noted for its recreational and aesthetic values. The Colorado River--already overextended, growing salty, and the subject of legal controversy--wil1 be a major source of water supply. Underground processing may, through temperature and pressure changes, alter aquifer hydraulics. Dewatering operations may produce large quantities of salty groundwater for disposal. If groundwaters reenter abandoned in situ retorts, they may be contaminated with organic compounds.

Therefore, this study will focus on probable environmental effects and mitigating measures. Potential problems that will be investigated include: subsurface water quality, water supply, underground leakage of exhaust gases, subsidence, and surface disposal of spent shale. These types of problems may require treatment, reuse, storage with release during noncritical periods, process modifications, and revegetation. It is anticipated also that the complex technical and legal issues surrounding the Colorado River will play a key role in the range, severity, and solution of such problems. 
The investigation will cross conventional disciplinary lines, drawing from chemical, sanitary, and civil engineering; hydrology; hydraulics, and water resources management. Laboratory analyses, field surveys, modeling, and planning will be integral parts of the study. Effluents will be characterized, treatment alternatives identified and pilot tested, and reuse and other water conservation measures analyzed. Water quality monitoring strategies will be developed and the impact of in situ processing on aquifer hydraulics and groundwater quality will be predicted. Flow alterations from terrain modifications will also be studied.

Routson, R. C. 1975. 1st Quarterly report on "Development of a chemical reactions, stability, and transport model of 0il-shale process wastes in soil." Contract TD 0747 between EPA and ERDA.

During the reporting period a large volume of literature was reviewed and spent shale and retort water were identified as the two classes of wastes most likely to be problems due to their large potential volumes and some of their preliminary characteristics. In addition, some samples of these two wastes are presently available in contrast to the other potential which were identified. Thus these two wastes were selected for the initial modeling effort.

Samples of spent shale and retort water were obtained from the Bureau of Mines, Laramie, Wyoming, simulated in situ oil shale retort. Spent shale was characterized as to its total and sohxlet extractable content of 24 elements by emmission spectroscopy. In general, elements which formed cations in solution were below the detection levels of the method with the exception of $\mathrm{Cu}$. Elements which generally form anions in solution including $\mathrm{B}$, Mo, and $\mathrm{Cr}$ were detectable. All of these elements plus $\mathrm{Cu}$ exceeded some standard for the use of waters. Thus these elements are the first that will be modeled. In addition, three other elements are potential problems, which are not easily measured by emission spectroscopy due to their moderate volatilities, including $F$, Se, and $A s$, and form anions in solution. These will be further investigated.

Satterfield, C. N., M. Mode11, J. F. Mayer, and J. F. Cocchetto. 1975. Catalytic desilfurization and denitrogenation. PB-248-101. (NTIS)

The report gives results of a study of catalytic desulfurization and denitrogenation, using thiophene and pyridine as model compounds because they represent some of the less reactive organosulfur and organonitrogen compounds. When thieophene is hydrodesulfurized simultaneously with the hydrodenitrogenation of pyridine (200 to $500 \mathrm{C}, 4.4$ and 11.2 bars pressure, commercial catalysts), the two reactions are mutually inhibitive at lower temperatures. At high temperatures, $\mathrm{H}_{2} \mathrm{~S}$ (a hydrodesulfurization reaction product) enhances the hydrogenitrogenation rate. The report proposes mechanisms to explain these observations. In hydrodenitrogenation of pyridine the other heterocyclic nitrogen compounds, the rate may be at least partly governed by the equilibrium of the first step, the hydrogenation of the $\mathrm{N}$-containing ring. (NTIS) 
Sladek, T. A. 1975a. "Recent trends in 0 il shale - Part 2: Mining and shale oil extraction processes." Colo. Sch. Mines Mineral Industries Bul1.

18(1): $1-21$.

One of the major potential solutions to our domestic fuel shortage is development of the enormous fuel resource locked in our oil shale deposits. The previous article in this series (Sladek 1974) described the nature of oil shale and outlined the history of its use. Worldwide resources were also discussed, with special emphasis on the oil shale deposits of the Green River formation of Colorado, Utah, and Wyoming.

In the current article, he discusses technical aspects of $0 i 1$ shale mining and describes a few of the many processes available for extracting hydrocarbon fuels by thermal treatment of oil shale. In the final article in the next issue, we will discuss refining of shale oil and will touch upon some of the economic, social, and political problems that affect the rate of oil shale development.

Sladek, T. A. 1975b. "Recent trends in oil shale - Part 3: Shale oil refining and some oil shale problems." Colo. Sch. Mines Mineral Industries Bull. 18(2): $1-11$.

In the second MIB (S1adek 1975) mining of oil shale was discussed, and the two techniques most amenable to mining of Green River shale were described. Thermal extraction of oil and gas from shale was discussed, and the classes of commercial retorts which are available for thermal conversion were defined. Current designs in each class were identified, and some of the advantages and disadvantages of each design were described.

In this, the final publication in the series, the topics discussed in the two previous issues are reviewed in detail. Current efforts towards developing the Green River shales are identified. The properties of crude shale oils from several retorts are listed.

Snyder, P. W., Jr., T. H. Timmins, and W. F. Johnson. 1975. An evaluation of in situ oil shale retorting. In: Penner, S. S. (ed.) Identification of Research and Development Priorities and of Costing Problems Associated with Implementation of in situ Recovery of Shale 0i1. PB-246-278: 174-210. (NTIS)

Description of Mobile 0il's modified in situ research.

Zitting, R. T. 1975. Solid fuels: their contributions to energy independence. Mining Congress J. 61(2): 42-44.

There is no energy shortage in the U.S.A. Only petroleum is in short supply. Solid fuel, especially coal is in abundance, so are uranium and oil shale. Artificial obstacles have to be removed from the way of the electrical generating industry so it can expand, raise money, and invest in energy production toward independence. 
Anon. 1974. 0il shale: A major U.S. fossil fuel resource. Institute of Gas Technology. Combustion 46(3): 12-16.

0il shale contains no oil but a rather waxy organic material called kerogen, and its inorganic matter is not shale but a laminated marlstone mixed with clay and sand. This relatively impermeable material requires chemical or thermal degradation methods to separate its organic and mineral components. A survey of attempts being conducted to refine oil shale from deposits of ores, containing some 35 gallons of oil per ton, is presented. 8 refs. (NTIS)

Bonomo, F. 1974. Environmental effects of carbonaceous solid wastes from commercial oil shale operations. In: Siggia, S. and P. C. Uden, (ed.). Analytical Chemistry Pertaining to 0il Shale and Shale 0il. ConferenceWorkshop June 24-25, 1974 at NSF. Washington, D.C. pp. 133-186.

Based on the investigations conducted to date, the following tentative summaries and conclusions can be made:

Carbonaceous spent shale (coke) from retorting for Green River oil shale with up to 5 percent carbon content, contains organic material soluble in organic solvents. The benzene soluble fraction ranges from about 0.01 to 0.2 percent depending on the retorting conditions and the age of the spent shale.

The benzene soluble fraction contains organic compounds with predominantly aliphatic character and some polynuclear organic matter such as polycyclic condensed aromatic hydrocarbons (PAH) and aza-arenes.

The polycondensed aromatic hydrocarbon and azarine fractions contain compounds with experimentally demonstrated carcinogenic properties, such as benzo(a)pyrene and dibenz( $a, j)$ acridine. Based only on the amount of benzo(a)pyrene present in the benzene soluble fraction from some of the cabonaceous spent shale (i.e. about $0.005 \%$ ), one can classify these extracts as more than mildly carcinogenic. The known presence of other compounds with carcinogenic properties may add to the effect of $\mathrm{BaP}$. However, their quantitative evaluation is as yet not completed and therefore further quantitative statements cannot be made.

Part of the soluble organic matter (and perhaps all organic carbon) appears to be subject to a slow oxidation process, and part of it is subject to leaching by water or slow volatilization in the air.

The percent amount of benzene soluble material in carbonaceous spent shale can be one to two orders of magnitude larger than that from soils collected from pristine areas but one order of magnitude lower than that obtained from collected airborne particulate matter of urban and industrial areas. However, on a volume basis (cubic meter of material) spent shale is higher in soluble material content by about twelve order of magnitudes. 
From traverse of a gulch projected as a potential disposal area the extractable organic material is, in general, also one or two order of magnitude lower than that from spent shale; however, it varies with the density of the vegetation growing at the particular sampling site. This can be attributed to the endogenic PAH compounds synthesized by the plants and ending up in the soil.

The content of benzo(a)pyrene in the benzene extracts is about three orders of magnitude higher than that found in the soil, plant and water samples collected from the pristine areas.

Preliminary data indicate that a large number of polycyclic aromatic compounds (including BaP) can be easily leached from the carbonaceous shale and migrate with the saline water. This water has a PAH content which may be at least three to four orders of magnitude higher than ground water or surface water from pristine areas.

Based on these preliminary findings one can state that in addition to the migration of inorganic trace elements there is a distinct possibility of uptake of solublized trace amounts of organic compounds by saline water in the carbonaceous shale dump subject to migration, possible concentration by accretion and translocation.

The presence of PAH compounds in the organic extracts and the water leached extracts is experimentally established and there is evidence that the concentration of some of these PAH compounds having carcinogenic properties is at a level which cannot be neglected or written off as inconsequential -and warrant further intensive study and monitoring in view of the large quantities of spent shale which will have to be disoposed of in commercial operations.

Making the assumption (which is very probably not valid) that benzo(a)pyrene is the only carcinogenic material present in the carbonaceous spent shale, the amount present could render this material mildiy carcinogenic. However, this is to be considered a very preliminary conclusion. The fact that other PAH compounds with potential carcinogenic effects, are present, i.e. the demonstrated presence of acridines, dibenzapridines and the potential presence of alkyl substituted $\mathrm{PAH}$ (some of which can be even more carcinogenic than the parent compounds) has to be taken into consideration and therefore the final answer will have to await forthcoming results from extended investigations.

Burwe11, E. L., and I. A. Jacobson, Jr. 1974. Usable gas from oil shale during retorting. Bur. of Mines 0 il Shale Program, Tech. Prog. Report 85.

The Bureau of Mines performed laboratory studies on the effect of system pressure, percentage of injected oxygen, and $0 i 1$ shale grade on the heating value and quantity of offgas produced during in situ retorting. Equations were developed that satisfactorily describe the system and that show that usable low-Btu gas may be produced in large quantities under field conditions. 
Carpenter, H. C., and H. W. Sohns. 1974. Development of Technology for in situ $0 i 1$ Shale Processes. Colo. Sch. Mines Quart. 69(2): 143-170.

Laboratory and pilot plant research is being conducted by the Bureau of Mines at the Laramie Energy Research Center to support the development of in situ retorting processes. Results of this research indicate that fairly wide ranges of gas velocity and oxygen concentration may be used to produce an optimum oil yield. Retorting advance rate increases with increasing oxygen flux but maximum oil yield does not occur at the maximum advance rate. 0ils produced by in situ retorting of oil shale will have lower pour points, higher API gravities, and a higher percentage of lower-boiling distillate fractions than will oils produced by many aboveground retorting processes. Total system gas pressure has an effect on oil yield and overburden pressure decreases the permeability of a bed of broken $0 i 1$ shale during retorting.

Cameron, R. J. 1974. Environmental groups express concern over oil shale to President Ford - Cameron responds. Synthetic Fuels 11(4): 2-50--2-55.

Letter by seven environmental groups to President Ford on September 19, 1974 expressing concern over federal policies which they feel are aimed at premature development of oil shale; as well as, a letter of rebuttal to President Ford by R. J. Cameron, Chairman of the Board of Cameron Engineers, are reproduced in their entirety.

Carlson, F. B., L. H. Yardumian, and M. T. Atwood. 1974. TOSCOAL process for low temperature pyrolysis of coal. Trans. Soc. Mining Eng. AIME 256(2): 128-131.

The $0 i 1$ Shale Corp. (TOSCO) is investigating the application of its oil shale retorting technology to coal processing in its 25-tpd retorting pilot plant. Low temperature char, with a high heating value, plus tar and gas have been produced from high moisture content, low heating value, subbutuminous coal. The process, which has been named TOSCOAL process, uses heated ceramic balls to provide the heat for retorting the coal. One ton of as-mined, subbituminous coal produces approximately one-half ton of char, one-half barrel of tar, and 1600 standard cubic feet (SCF) of gas when the retorting is conducted at $970^{\circ} \mathrm{F}$. Properties and yields of the products are presented and compared with Fischer assay yields. 2 refs. (NTIS)

Conkle, N., V. Ellzey, and K. Murthy. 1974. Environmental considerations for oil shale development. PB-241-942. (NTIS)

Results of a preliminary literature study of the environmental considerations in the development of an environmentally acceptable oil shale industry are presented. The following seven different areas are included in the study. 
0i1 Shale Deposits

Mining, Handling, and Pretreatment Processes

In-Situ Retorting

Ex-Situ Retorting

Retorted Shale Refuse Disposal

Other Environmental Considerations

Product Treatment and Usage

Cook, E. W. 1974a. 0il shale technology in the U.S.A. - A review of current problems and prospects. Fuel 53(3): 146-151.

Review covers the subjects of retorting methods, alternative uses of oil shale, and oil shale's probable future.

Cook, E. W. 1974b. (Project Coordinator) Surface rehabilitation of land disturbances resulting from oil shale development. Technical Report Series No. 1 (final report. phase 1). Environmental Resources Center, Colorado State University, Fort Collins, CO.

Report covers subjects:

Geomorphology of Piceance Creek Basin

The natural vegetation in the landscape of the Colorado oil shale region

Ecosystems and their natural and artificial rehabilitation

Evaluation of mining techniques

Physical and chemical characteristics of overburden, spoils, and soils

Characteristics of spent shale which influence water quality, sedimentation and plant growth medium.

Cooley, F. G. 1974. The physical background. Colo. Sch. Mines Quart. 69(2): $109-117$.

Remarks were divided into three topics: the relationship of oil shale to the Persian Gulf; the White River; and a discussion of the key documents in an oil shale library. An in depth discussion of what is needed to obtain water for an oil shale industry of $10^{6} \mathrm{bbl} /$ day. 
Decora, A. W. 1974. Environmental considerations of shale oil program. In: Analytical Chemistry Pertaining to 0il Shale and Shale 0il, Siggia, S. and P. C. Uden, (ed.). Conference-workshop 24-25, June 1974 at NSF Washington D.C. pp. 101-132.

Discussion of the impact of a shale oil industry on Dept. of Interior lease sites.

Fischer, R. C. 1974. Colorado oil shale and water. Colo. Sch. Mines Quart. $69(2): 133-139$.

Colorado is pressing forward both our planned irrigation projects: we are not willing to trade off totally our western Colorado agricultural base for the production of energy. We just are not ready to let the money market alone make the decisions about the relative value of a bushel of peaches vs. a barrel of oi1. The River District thinks that a11 of these uses can be accommodated, but just as Colorado is perfectly capable of making its own energy environmental decisions, the decisions as to how Colorado's water is to be used must be made in Colorado, by Colorado, and not in Houston, Los Angeles, New York or Washington, DC.

Giltner, R. E., R. C. Fischer, J. J. Hester, H. C. Carpenter, H. W. Sohns, P. W. Marsha11, C. W. Livingston, L. Goodfellow, M. T. Atwood, P. R. Reed, Jr., and P. L. Warren. 1974. In: Proceedings 7th $0 i 1$ Shale Symposium. 1974. Colo. Sch. Mines Quart. 69(2): 1-231.

Following is a list of titles and authors: Western Colorado: Choices for Growth by Robert E. Giltner, Colorado $0 i 1$ Shale and Water by Roland C. Fischer, Cultural Resources of Western Colorado by James J. Hester, Development of Technology for In Situ Oils Shale Processes by Harry C. Carpenter and Harold W. Sohns, Colony Development Operation Room-and-Pillar $0 i 1$ Shale Mining by Paul W. Marsha11. 0il Shale: A Roadblock and a Solution by Clifton W. Livingston, Fischer Assay of $0 i 1$ Shale Procedure of the $0 i 1$ Shale Corporation by Lawrence Goodfellow and Mark T. Atwood, Rapid Determination of Recoverable $0 i 1$ in $0 i 1$ Shale by Thermal Analysis by PP. Robert Reed, Jr., and Philip L. Warren. (NTIS)

Hartley, F. L. 1974. Shale - another resource of oil for the United States. Paper presented at $0 i 1$ Daily's 3rd Annual Synthetic Energy Forum, New York, NY. 10 June 1974.

A discussion of an oil shale research project outlining some of the problems that are involved in pioneering the development of a vast but untouched natural resource of the United States. 
Heley, W. 1974. Processed shale disposal for commercial oil shale operation. Mining Congress J. 60(5): 25-29.

Disposal of waste products entails both economic and ecological expenses which may be mitigated by location of an alternate beneficial use. Colony has provided samples of processed shale to both independent manufacturers and consulting research laboratories for examination of its material properties. To date, several uses have been found, including manufacture of lightweight, high-strength cement, various types of filler in synthetic materials production, and a probable use in asphaltic concrete mixtures. But none of these uses has a significant volume potential in the Rocky Mountain region compared to the production rate of 50,000 tpd. Therefore, disposal as described will be necessary to a substantial degree throughout the project 1 ife.

Hendrickson, T. A. 1974a. Shale oil process choices. Chem. Eng. (NY) $81(10)$ : 66 and 68-69.

Some of the routes being groomed for production of shale oil are described. One of these, the Tosco II process, is already considered proven and is on the verge of commercialization. (NTIS)

Hendrickson, T. A. 1974b. $0 i 1$ shale processing methods. Colo. Sch. Mines Quart. 69(2): 45-70.

When considering processes for converting oil shale to conveniently usable liquid and gaseous fuels, retorting always emerges as the most appropriate process. It is the purpose of this author to present brief reviews of the several retorting processes of current interest.

Retorting may be defined as the distilling or the decomposing of a material under the influence of heat. $0 i 1$ shale is a rock which consists of a mixture of organic matter (called "kerogen") and inorganic matter, such as dolomite, quartz, clay, calcite and other materials. When oil shale is retorted, it is the kerogen that decomposes or pyrolyzes when heated. Most of the inorganic rock minerals are unaffected by the relatively low temperature range of 900 to $1000^{\circ} \mathrm{F}$ needed for rapid pyrolys is of kerogen.

Jackson, L., P. C. S. Allbright and H. B. Jensen. 1974. Semimicro procedure for the determination of hydrocarbon types in shale-oil distillates. Anal. Chem. 46(4): 604-607.

Destructive removal of olefins offers several advantages over existing techniques for the quantification of the hydrocarbon types in shale-0il distillate fraction. Handling and manipulation of the sample is minimal: an elution chromatography is the only preparation prior to analysis. The method avoids the problems associated with chemical and physical procedures normally used to quantify the three functional types; the 
specificity of compound-type removal, coupled with the accuracy of the GC readout, gives improved results for complex mixtures containing a significant concentration of olefinic material. The technique is amenable to batch analysis of a large number of samples, and automated GC makes the data readout step a simple operation not requiring extensive operator time. An accurate analys is can be performed on samples as small as 50 milligrams, and the sample may be in the form of a dilute solution.

Katel1, S., R. T. Stone, and P. Wellman. 1974. 0i1 shale - a clean energy source. Colo. Sch. Mines Quart. 69(2): 1-20.

The need to develop supplemental energy sources and at the same time to satisfy our present environmental standards with a flexibility to meet new or higher standards as we move toward the twenty-first century is not only desirable, but a definite requirement for our nation today. Shale $0 i 1$, one of our most abundant resources, needs to be developed to take its place among the usable reserves of our energy supplies in the future. High-grade oil shales found in the Green River formation in Colorado, Utah, and Wyoming have been estimated to contain the equivalent of 600 billion barrels of oil which is equal to the total known world reserves of $0 i 1$.

Environmental concerns are broad and encompass not only the industrial complex but the effect on the surrounding socjo-economic area and region. This presentation is focused on the industrial activities and on the responsibilities of a potential developer.

Kilburn, P. D. 1974. Environmental program for a commercial shale oil complex. Environmental Conservation 3(2): 101-115.

This article describes a $\$ 3$ million environmental program initiated to assess potential environmental impact on air, land, water, wildlife, vegetation and socio-economic conditions which could result from the construction and operation of an oil shale complex designed to process approximately 66,000 tons/day of oil shale. Major aspects of the 113 studies conducted to minimize the adverse environmental effect of the complex are discussed along with the use of the TOSCO II process for producing shale oil.

Kimble, B. J., J. R. Maxwe11, R. P. Philip, G. Eglinton, P. Albrecht, A. Ensminger, P. Arpino, and G. Ourisson. 1974. Tri- and tetraterpenoid hydrocarbons in the Messel oil shale. Geochim. Cosmochim. Acta. 38: $1165-1181$.

The high molecular weight constituents of the branched and cyclic hydrocarbon fraction of the Messel oil shale (Ecocene) have been examined by high resolution gas chromatography and combined gas chromatography--mass spectrometry. The following compounds are 
present: perhydrolycopene $(1 ;$ lycopane), together with one or more unsaturated analogues with the same skeleton; a series of 4-methylsteranes (2c) in higher abundance than their 4-desmethyl analogues; two series of pentacyclic triterpanes, one series $\left(C_{27}-C_{31}\right)$ based on $n$ the $17 \alpha-\mathrm{H}$ hopane structure $(3 \mathrm{a}-\mathrm{d}, 17 \alpha \mathrm{H})$; and an intact triterpene hop$17(21)$-end !3c, $\Delta 17(21) 1$. Only two additional triterpanes were detected in minor concentrations, viz. 30-normorethane $(3 \mathrm{~b}, 21 \alpha \mathrm{H})$ and a $\mathrm{C}_{31}$ triterpane based on the hopane/lupane-type skeleton. The presence of these compounds suggests a significant microbial contribution to the forming sediment. Comparison of the tri- and tetra-terpenoid hydrocarbons with those of the Green River Shale indicates differences in the organisms contributing to the two sediments.

Linden, H. R. 1974. Program for maximizing U.S. energy self-sufficiency. Energy System Policy 1(1): 41-63.

It is the purpose of this study to quantify the various domestic sources of energy which could reduce the level of oil import requirements to about 4-4.5 million bbl/day by 1975-1980 and permit gradual elimination of oil imports by 2000, while allowing for a continued increase in primary energy consumption of about $4 \%$ annually. The key measure would be the creation of a synthetic fuels industry, initially based on conversion of coal and oil shale to clean gaseous and liquid fuels by means of existing technology. If this is coupled with (1) an increase in the direct use of coal of $3 \%$ per year, (2) increases in domestic production of $0 i 1$ and natural gas to levels considered feasible by the National Petroleum Council and others, (3) roughly doubling the 1980 level of synthetic fuels production by 1985 and again by 1990 , and (4) the assumption that the contribution of nuclear energy will grow at the maximum rate that can be produced at present, it should be possible to keep the impact of reduced energy imports within acceptable limits.

Livingston, C.W. 1974. 0 il shale: a roadblock and a solution. Colo. Sch. Mines Quart. 69(2): 185-203.

A roadblock to long-range development of a United States shale oil industry exists because the natural resources of a vast area simply cannnot be developed using conventional concepts of mine layout and mine development, and because the conservation of these resources is essential to long-range development of oil shale.

The solution to development of natural resources within the 16,000 square mile area underlain by oil shale of the Green River formation of Colorado, Utah, and Wyoming requires the joint efforts of industry, local, state (Colorado, Utah, and Wyoming), and federal government. These efforts must be effectively organized and coordinated. 
If moisture falling upon the region is to be made available both to Upper and Lower Colorado River Basin states; if stream pollution attributable to mining, processing, and spent shale disposal is to be avoided; if stream beds and drainage basins are not to be destroyed by mining subsidence (which follows mining as surely as night follows day); if plant and animal life within the region are to be protected in accordance with requirements of ecology and the natural environment; and if as a result of man's work the land becomes a monument to his vision rather than a gravestone identifying his lack of it, the interdependence of the methods of the future, the vastness of the deposits to be mined, and the interdependence of natural resource development and water resources development first must be recognized.

Marsha11, P.W. 1974. Colony Development Operation room-and-pillar oil shale mining. Colo. Sch. Mines Quart. 69(2): 171-184.

McDonald, F. R. 1974. Identification of $\gamma$-valerolactone in waste water from an oil-shale in situ retort. U.S. Bur. Mines RI 7918, 8 p.

The compound $\gamma$-valerolactone has been identified in an acid fraction isolated from waste water collected from an in situ oil-shale retort. Infrared, nuclear magnetic resonance, and mass spectrometry were used by the Bureau of Mines to confirm the identification of a subfraction collected from a gas chromatograph.

Metz, W. D. 1974. 0il shale: a huge resource of low-grade fuel. Sci. 184: $1271-1275$.

Review with many questions.

Meyer, W. C., and T. F. Yen. 1974. Effects of bioleaching on Green River oil shale. Am. Chem. Soc., Div. Fuel Chem. Preprint 19(2): 94-99.

Bioleaching, utilizing a sulfuric acid medium generated by the sulfur oxidizing capabilities of Thiobacillus spp. has proved to be useful in releasing hydrocarbons from petroliferous rocks from the Mahogany Ledge of the Green River Formation. The purpose of this paper is to investigate the texture and mineralogy of the Green River shale to ascertain the nature of kerogen entrapment and the physical effects of bioleaching. Bioleaching effectively removes carbonate minerals from the shale eliminating matrix material, and thereby developing porosity and permeability which are effectively nil for untreated shale. This brings more rock surface in contact with the leaching medium, increasing solution of matrix and enlarging pathways for migration of liberated hydrocarbons. Carbonate removal during bioleaching proceeds rapidly upon exposure to the leaching medium, and continues as a function of time. (NTIS) 
Miknis, F. P., A. W. Decora, and G. L. Cook. 1974. Pulsed nuclear magnetic resonance studies of oil shales: estimation of potential oil yields. U.S. Bur. Mines RI 7984.

Previous studies at the Bureau of Mines have shown that Broad-line nuclear magnetic resonance (NMR) techniques have potential applications for rapid evaluation of oil-shale deposits. The techniques of pulsed NMR have been applied in a similar manner. The basis for the pulsed NMR oil-shale assay method lies in the assumption that the free induction decay (FID) amplitude following a 90 degree pulse is proportional to the potential oil yield. This assumption was tested on two groups of oil-shale samples, numbering 141 and 263 samples, from two different oilshale cores. For both groups of samples a small number were selected as calibration samples. Free induction decay amplitude measurements were made on the 141 and 263 samples. The agreement between measured and calculated oil yields was good, the indexes of determination being 0.93 and 0.89 for the groups of 141 and 263 samples, respectively. 11 refs.

Pfeffer, F. M., and R. S. Kerr. 1974. Pollutional problems and research needs for an oil shale industry. EPA-660/2-74-067. (NTIS).

The oil shale resources and surface stream drainage within the Green River Formation of Colorado, Utah, and Wyoming are presented briefly. The aboveground retorting processes of the Bureau of Mines, Union $0 i 1$ Company, and The $0 i 1$ Shale Corporation are described, as are the physical and leaching characteristics of spent shale residues derived from each process. $0 i 1$ shale retorting in place (in situ) is summarized.

The area of major concern, stabilization of spent shale residues, is covered in detail. Other areas of environmental concern are discussed: retort wastewater, process water from shale-0il upgrading, dewatering operations, mineral recovery, and contamination of groundwater by radioactivity. Research needs are presented: a tri-state groundwater report; environmental base line data; an assessment of total environmental impact; pollution control guidelines; effluent limitations; and continuous EPA monitoring.

Pforzheimer, H. 1974. Paraho--new prospects for oil shale. Chem. Eng. Prog., 70(9): 62-65.

Pikul, R. P., and R. Rabin. 1974. Program plan for environmental effects of energy. Prepared for Nat'l Sci. Foundation by Mitre Corporation, McLean, VA. MTR67: 6, $309 \mathrm{pp}$.

This document presents the NSF's initial five year program plan for the environmental effects of energy. It consists of a basic program for five energy sources--coal, oil and gas, oil shale, geothermal and solar. It also identified preobligated projects, new environmental support studies and program planning and evaluation needs. 
Piper, E. M. 1974. Current status of oil shale. Paper presented at joint ASME and AIChE at Golden, CO, 19 November 1974.

Poulson, R. E., C. M. Frost, and H. B. Jensen. 1974. Characteristics of synthetic crude from crude shale oil produced by in situ combustion retorting. Am. Chem. Soc., Div. Fuel Chem. Preprint. 19(2): 175-182.

The nitrogen contents of in situ crude shale oils may be somewhat lower than those of crude shale oils produced in other retorts; however, these in situ oils still contain more than twice as much nitrogen as high-nitrogen petroleum crude oils. Because existing refineries would not be able to cope with the high nitrogen content of shale oil if it were a substantial portion of the refinery feed, the National Petroleum Council (NPC) has suggested that crude shale oil be upgraded at the retorting site by a catalytic hydrogenation process to produce a synthetic, premium feedstock called "syncrude." The production of such a syncrude from in situ crude shale, a description of its bulk properties, and a comparison of its properties to those of an NPC-type syncrude have been covered by C. M. Frost earlier in this symposium.

Reed, P. R., Jr. and P. L. Warren. 1974. Rapid determination of recoverable oil in oil shale by thermal analysis. Colo. Sch. Mines Quart. 69(2): 221231.

Determination of recoverable oil in Green River oil shale and separation and analysis of bitumen and kerogen components was accomplished with the MP-3 thermal chromatograph. Recoverable oil in Green River oil shale determined with the MP-3 correlated well with Fischer assay results. Chromatographic data confirmed that it is possible to separate bitumen and kerogen thermally.

Rogers, M. P. 1974. A bibliography of oil shale and shale oil. Laramie Energy Research Center, U.S. Bur. of Mines.

Bibliography by year

Russe11, P. L. 1974. Some environmental aspects of large scale oil shale mining. In: Rapid Excavation and Tunneling Conf. Proc. Soc. of Min. Eng. of AIME. 1: 861-873.

U.S. petroleum demand has increased at a rate greater than that of domestic production. A domestic energy source that is under serious consideration to augment present supply is oil shale.

The Green River Formation in Colorado, Utah, and Wyoming represents a resource potential containing about 2 trillion barrels of $0 i 1$ in shales averaging 15 gallons or more per ton or more than 400 billion barrels in 30 gallon per ton shales. This paper will consider the technological and environmental aspects of developing this resource. 
Schmidt-Collerus, J. J. 1974a. The disposal and environmental effects of carbonaceous solid wastes from commercial oil shale operations. NSF-RA/ E-74-004 (NTIS), 269 p.

The major by-products from oil shale retorting are the solid spent shale, the process water generated during pyrolysis and process gases. Studies carried out in the past show that chronic exposure to inorganic and organic carcinogenic trace substances can have a detrimental effect on ecology. The potential impact from trace organic matter from carbonaceous spent shale has not been investigated to date. The main objective of the present program is to fill this gap. Samples of soil, water, vegetation, and air from various pristine areas of potential oil shale operations were collected and analyzed for their polycyclic organic matter content. Samples of carbonaceous spent shale from retorting in pilot plants were also analyzed for polycondensed aromatic compounds. This was done to establish a base line for future comparative studies. (NTIS)

Schmidt-Collerus, J. J., F. Bonomo, and C. H. Prien. 1974b. Polycondensed aromatic compounds (PCA) and carcinogens in the shale ash of carbonaceous spent shale from retorting of $0 i 1$ shale of the Green River Formation. Am. Chem. Soc., Div. Fuel Chem. Preprint 19(2): 115-122.

This paper reviews oil shale deposits in the United States, chemistry and structure of oil shale, the possible technology in regard to their utilization for hydrocarbon production. Potential environmental impact of the future oil shale industry is discussed with particular attention to carbonaceous matter ( 3 million tons/yr) which may contain as much as 6,000 tons of solubilizable and in part volatile organic compounds. It is conceivable that even a small portion of these organic compounds may have (in the long run) some undesirable impact on the ecosystem. The exposition of the more detailed potential problems involved, and methods of approach utilized, and the preliminary experimental results obtained to date are summarized. (NTIS)

Schmidt-Collerus, J. J., and C. H. Prien. 1974c. Investigations of the hydrocarbon structure of kerogen from oil shale of the Green River Formation. Am. Chem. Soc., Div. Fuel Chem. Preprint 19(2): 100-108.

Colorado $0 i 1$ Shale of the Green River Formation contains about 16 percent insoluble organic matter, the so-called "kerogen". An experimental study is reported in which the structure of "kerogen" was elucidated by using the MPGM-method. By using the combination of micro-pyrochromatography and mass spectrometry it has been shown that "kerogen" consists of a three-dimensional organic matrix of high molecular weight. The hydrocarbon portion of the matrix itself appears to consist of polycyclic "protokerogen" subunits or nuclei (of tetralin, terpenoid, phenanthrenoid and steroid type structure) interconnected by long chain alkanes and isoprenoids to form the threedimensional network of the "kerogen" matrix. The chemical structure of the "protokerogen" subunits identified by macropyrolysis, chemical cleavage and by the MPGM-method used in conjunction with reaction chromatography are described. The possible relationship between geochemical origin of $0 i 1$ shale are discussed. (NTIS) 
Scrima, D. A., T. F. Yen, and P. L. Warren. 1974. Thermal chromatography of Green River oil shale--1. Bitumen and kerogen. Energy Sources 1(3): 321-336.

A number of thermograms and chromatograms were obtained by means of thermal chromatography from the Green River oil shale. Results indicated that bitumen can be separated efficiently from oil shale by controlled thermal heating. The chromatogram of thermally separated bitumen is identical to that of the solvent-extracted bitumen. Chromatograms of kerogen concentrate support the hypothes is that kerogen structure is a complex matrix made of multiple components. (NTIS)

Siggia, S., and P. C. Uden, (ed.) 1974. Report of the conference-workshop: Analytical Chemistry Pertaining to 0il Shale and Shale 0il. 24-25 June 1974 at the National Science Foundation, Washington DC.

This report covers the material formally presented, together with the discussion and exchange of ideas that took place at the Conference-Workshop entitled "Analytical Chemistry Pertaining to 0il Shale and Shale 0il" held under the sponsorship of the National Science Foundation (through Grant GP 43807 ) in Washington, DC on June $24-25,1974$. The purpose was to acquaint the analytical chemical community with the problems involved in oil shale technology and shale oil production, and thereby to encourage analytical chemists to develop new methodology or new applications of existing methodology applicable to analytical problems in this area.

The invited participants in this conference-workshop included representatives of research institutions, oil companies, shale oil engineering and chemical companies. Also involved were academic people interested in working with oil shale or shale oil, representatives of analytical instrumentation companies, and of the federal government. The attendees included engineers, analytical chemists, biologists, geologists and administrators, the group being somewhat limited in size in order to better stimulate interaction and discussion.

Presentations:

1. Kuhn, E. A. National energy policy involving oil shale.

2. Findeis, A. F. Energy perspectives from the National Science Foundation.

3. Abernathy, F. H. National Science Foundation General energy related research.

4. Breger, I. A. The origin and composition of oil shales.

5. Jensen, H. B. Historical survey of the study of the qualitative and quantative nature of shale oil. 
6. Atwood, M. T. 0 il shale developments -current status.

7. Snider, D. Underground nuclear explosions for in situ oil shale retorting.

8. Yen, T. F. Facts leading to the biochemical method of oil shale recovery.

9. Cottingham, P. L. Refining considerations for chemical analysis pertaining to shale oil.

10. Decora, A. W. Environmental consideration of the oil shale program.

11. Bonomo, F. Environmental effects of carbonaceous solid wastes from commercial oil shale operations (auth).

Silver, H. F., N. H. Wang, H. B. Jensen, and R. E. Poulson. 1974. A comparison of shale gas oil denitrification reactions over Co-Mo and $\mathrm{Ni}-\mathrm{W}$ catalysts. Am. Chem. Soc., Div. Fuel Chem. Preprint 19(2): 147-155.

The selectivity of three catalysts ( $\mathrm{Co}-\mathrm{Mo}$ on $\mathrm{Al}_{2} \mathrm{O}_{3}$, and $\mathrm{Ni}-\mathrm{W}$ on $\mathrm{SiO}_{2} \cdot \mathrm{Al}_{2} \mathrm{O}_{3}$ ) on influencing the conversion of five, identifiable types of nitrogen compounds has been demonstrated. The two $\mathrm{Ni}-\mathrm{W}$ catalysts are somewhat more selective in converting quinoline-type compounds than is the Co-Mo catalyst because there is no difference in the selectivity toward primary and secondary amines. The Co-Mo catalyst converts amide-type nitrogen much faster at low levels than do the two $\mathrm{Ni}-\mathrm{W}$ catalysts; but all three catalysts are highly selective in promoting conversion of amide-type nitrogen.

The results also show that the relative percentages of different nitrogen compounds change as shale gas $0 i 1$ is denitrified. At low and intermediate levels of nitrogen removal, all five types of nitrogen compounds are present in the liquid product. However, at higher levels of nitrogen removal, the identifiable nitrogen compounds remaining in the liquid product consist primarily of quinolines, indoles, and arylamines. Primary and secondary amines and amides are practically missing from the product at levels approaching 80 percent removal of nitrogen. At low denitrification levels, all three catalysts are effective in rapidly converting indole-type nitrogen, but above 20 percent nitrogen removal, the Co-Mo catalyst is more effective than the $\mathrm{Ni}-\mathrm{W}$ catalysts. All three catalysts show that they are less effective in converting arylamines than they are in removing nitrogen; and they show approximately the same selectivity toward primary and secondary amines. 
Sladek, T. A. 1974. Recent trends in oi1 shale--Part 1: History, nature, and reserves. Colo. Sch. Mines Mineral Industries Bul1. 1(6): 1-20.

In this MIB, the nature of oil shale is discussed, and a brief history of oil shale development is presented. The worldwide and domestic oil shale resources are described, with emphasis on recent geologic exploration of the Green River Formation. In the next bulletin, oil shale mining and fuel extraction will be considered. The current status of the domestic oil shale industry will be discussed with emphasis on projects underway in Colorado and Utah. The third MIB will discuss technical problems of shale oil refining and some economic and social problems of oil shale development.

Smith, C. D. 1974. Unique approach to get oil shale out of the ground. Min. Eng. (NY) 26(10): 52-56.

Postulate--The U.S. needs alternate domestic sources of fuels.

Axiom--A geologic deposit of oil shale exists in a confined area.

Hypothesis--This oil shale deposit contains more oil than the sum of all other proven reserves in the world.

Thesis--Find the means of producing the oil from this deposit to produce a new source of wealth for U.S. citizens.

Corollary--Unitize the basin and dedicate an area to the production of synthetic crude $0 i 1$ and to the byproducts associated with the deposit.

Synthesis--Formulate a master plan of a mining layout of the utilized area designed to achieve maximum recovery of the synthetic crude oil and the byproducts.

The obvious question arises immediately. If the basic problem is this simple, why has man spent so much time and money on it?

Why has the solution not been found? Why has oil shale under the supervision of man been handled in such a cockeyed manner? The answer is also simple:

Man has neglected to apply the principles of logic, of elementary science, and of basic engineering. 
Spence, H. M. 1974. The environmental story. Colo. Sch. Mines Quart. $69(2): 79-84$.

Rather than attempt to discuss the substantive components of an oil shale environmental study, which have been discussed and reviewed on many occasions similar to this, and which are included in considerable detail in the Environmental Statement for the Federal Prototype 0il Shale Leasing Program, I would like to discuss in general terms the environmental regulatory scheme and the administration of environmental work from the standpoint of a prospective developer of oil shale.

Sparks, F. L. 1974. Water prospects for the emerging oil shale industry. Colo. Sch. Mines Quart. 69(2): 93-101.

A summary of the various water requirement estimates for a million bbl per day industry is as follows:

- Cameron and Jones in 1959, 130,000 acre-feet;

- Denver Research Institute in 1954, 145,000 acre-feet;

- Department of the Interior in 1973, 155,000 acre-feet;

- Colony Development Operation in 1974 (extrapolation), 175,000 acre-feet.

As you can see, the estimates have been gradually creeping upwards, and we strongly suspect that the true figure will be even higher. The first two estimates did not take into account the water requirements for processed shale disposal, revegetation, and the production of electrical energy. Neither did the earlier estimates take into account the necessity to prevent high concentrations of dissolved solids, principally calcium carbonate, from being discharged into the Colorado River.

Based upon increased attention to environmental and salinity factors, the staff of the Colorado state water board believes that all estimated heretofore made are too low. They believe that the consumptive use of somewhere between 200,000 and 250,000 acre-feet of water per year will be required to support a million barrel a day shale oil industry. Until a lesser requirement is actually demonstrated, the state planning is proceeding on this basis.

Stone, R. T., H. Johnson and A. W. Decora. 1974. 0il shale development and its environmental considerations. Am. Chem. Soc., Div. Pet. Chem. Preprint 19(3): 510.

The petroleum shortage recently experienced by many nations throughout the world has created an intense interest in obtaining new and supplemental energy sources. In the United States, this interest has been centered on oil shale. This paper outlines the program, the organization structure that was created for this specific task, and the environmental concerns which were investigated. (NTIS) 
Subcommittee on Energy, U.S. House of Representatives Staff. 1974. $0 i 1$ shale with new technology, the impact may be significant soon. Energy News Notes Issue 5: 1-2.

$0 i 1$ shale report for congress.

Yen, T. F. 1974. New structural model of oil shale kerogen. Am. Chem. Soc., Div. Fuel Chem. Preprint 19(2): 109-114.

In the reported investigation the kerogen (which is usually defined as the insoluble fraction of organic components of oil shale) concentrate of Green River oil shale was studied by using X-ray diffraction method. Experimental results are presented aand discussed in terms of possible structural arrangement of kerogen. It is concluded that there is little or no aromatic carbon skeleton in kerogen. Aromaticity for this kerogen approaches zero. The bulk of the carbon structure is naphthenic containing 3-4 rings. There is no free-end and flexible long-chain linear polymethylene structures in this kerogen. The structure of kerogen is a multi-polymer consisting of monomers which are the molecules so far identified from bitumen. Hypothetical structural model is proposed. 18 ref. (NTIS)

Young, D. K., S. Shih, and T. F. Yen. 1974. Stepwise oxidation of bioleached oil shale. Am. Chem. Soc., Div. Fuel Chem. Preprint 19(2): 169-174.

An experimental program is reported in which oil shale samples were pretreated by solute hydrochloric acid (in place of direct bioleaching with the acid medium of the sulfuric oxidizer) and then extracted with benzene/ methanol mixture. The hydrocarbon fraction from the soluble material was analyzed by gas chromatography. Next step was a step wise permanganate oxidation of extracted samples. A portion of the oxidation product was dissolved in pyridine- $d_{5}$ and subjected to NMR analysis. The results of the present investigation indicates that oxidative release of the entrapped organic material in an aqueous medium is possible without the necessity of disaggregating or dissolution of the resistant mineral. Under the mild oxidative conditions used a signficant amount of the organic matter is released as soluble acids (ca. $9.78 \%$ of the total raw shale. Recommendations for practical uses are given. 10 refs. (NTIS) 
Anders, D. E., F. G. Doolittle, and W. E. Robinson. 1973. Analys is of some aromatic hydrocarbons in a benzene-soluble bitumin from Green River oil shale. Geochim. Cosmochim. Acta. 37: 1213-1228.

The hydrocarbon content of an aromatic fraction, isolated from the bitumen of Green River shale, was studied by mass spectrometry, infrared spectrometry, gas chromatography and a dehydrogenation technique. The hydrocarbon types and their distribution in this aromatic fraction as determined by mass spectrometry, include the following: $\mathrm{C}_{n} \mathrm{H}_{2 n-6}(10 \%)$, $\mathrm{C}_{n} \mathrm{H}_{2 n-8}(31 \%), \mathrm{C}_{n} \mathrm{H}_{2 n-10}(18 \%), \mathrm{C}_{n} \mathrm{H}_{2 n-12}(12 \%), \mathrm{C}_{n} \mathrm{H}_{2 n-14}(8 \%)$ and $\mathrm{n}$ series of alkenylbenzenes $(20 \%)$. The carbon-number range, emperical formulae and quantity of each compound in the major types are reported. Mass spectra of several compounds. and homologous mixtures of compounds isolated from the aromatic fraction are also given.

Bloch, M. B. and P. D. Kilburn, (ed.). 1973. Processed shale revegetation studies, 1965-1973. Colony Devel. Operation, Denver, CO.

Partial Contents:

Article 2. $\quad$ On p. 7 "Some properties of spent oil shale significant to plant growth," by W. R. Schmehl and B. D. McCaslin.

Article 3. On p. 27 "Green house experiment of plant growth in processed shale," by Lawrence Schaal.

Article 6. $\quad$ On p. 57 "Vegetation establishment demonstration (1971) on TOSCO-II processed shale," by W. A. Berg.

Article 9. On p. 109, "Growing house plants in processed shale," by W. J. Duffield.

Article 10. On p. 115 "Chemical material of TOSCO-II processed shale and their interpretations relative to plant growth," by W. A. Berg.

Spent shale texture, $\mathrm{pH}, \mathrm{CEC}$, soluble salt, $\mathrm{Na}$, lime, organic matter, $\mathrm{NO}_{3}, \mathrm{NH}_{X}, \mathrm{P}, \mathrm{K},(\mathrm{a}, \mathrm{Mg}, \mathrm{S}, \mathrm{E}, 10.9$ to $>6 \mathrm{ppm}), \mathrm{Zn}, \mathrm{Fe}, \mathrm{Mn}, \mathrm{Cu}$, Sodium adsorption ratio were analyzed. 
Burwel1, E. L., T. E. Sterner, and H. C. Carpenter. 1973. In situ Retorting of oil shale: Results of two field experiments. U.S. Bur. Mines RI 7783.

Application of the in situ recovery process to oil shale was tested during two field experiments near Rock Springs, Wyoming. The results of these tests demonstrate that a self-sustaining combustion zone can be created in an oil shale body, that this zone can be moved through the oil shale, and that the process will produce shale oil.

Evaluation of the combustion process by monitoring produced fluids for physical and chemical properties and volumes is described. The material and energy balance obtained is compared with a second evaluation based on extensive coring of the test area after the test was terminated.

Several side results of the research are noted such as ground surface heating by underground burning and production of low- to medium-Btu gas during retorting.

Coffin, D. L., and J. D. Bredehoeft. 1973. Digital computer modeling for estimating mine-drainage problems. (Piceance Creek Basin, northwestern Colorado). Colorado Geol. Survey Report Open File No. 5. 24 pp.

Many ground water problems may be solved if the response of an aquifer system to known hydrologic stresses can be predicted. If the spatial distribution of the aquifer diffusivity and the aquifer boundary and initial conditions can be described, then the digital computer may be used to solve numerically the partial differential equations of flow. Using digital modeling techniques the pumpage necessary to drain an oil-shale mine in northwestern Colorado is predicted. The alternating direction implicit numerical procedure is used to solve the flow equations. These numerical methods treat the aquifer as nonhomogeneous and anisotropic and decrease the transmissivity as the aquifer is unwatered. The results indicate that it will be necessary to pump and dispose of rather large quantities of brine.

Cook, E. W. 1973. Elemental abundances in Green River oil shale. Chem. Geol. 11: 321-324.

Spark-source mass spectrometric analysis of pyrolyzed Green River oil shale for trace element distribution showed enhanced concentrations for only lithium and beryllium. In general, trace elemental concentrations were found to be below anticipated crustal amounts. There appears to be no promise of any substantial accumulation of any trace elements within the organic matrix of Green River oil shale. 
Dana, G. F., and Smith, J. W. 1973. Black trona water, Green River Basin. Twenty-fifth Field Conference-1973. Wyoming Geological Asso. Guidebook, p. 153-156.

Black water has been found in 18 boreholes drilled since 1949 in an area around Farson and Eden in the northern Green River Basin. The black water is produced from unusually porous and permeable oil shales of variable richness in the Wilkins Peak Member of the Green River Formation. The black water color is caused by organic acids dissolved in a sodium carbonate solution. Because of minimal information, the explanation of the occurrence of the porosity, permeability, and the presence of black water in a usually impermeable shale is difficult and requires furtiner study. However, in our opinion, the black water is original lake water incorporated in the sediments in a low place in the lake bed during recessions of the lake. Further deposition created closed aquifers which, when penetrated by drilling, produce artesian water due to overburden pressure rather than by the more common mechanisms of gas pressure or hydrodynamic drives. Since 1949, attempts have been made to produce the water for economic exploitation, but no economic use has yet been found for it.

Dept. of Interior Staff. 1973. The prototype oil-shale leasing program. EIS-AA-73-1423-F. 6 Volumes. (NTIS)

This action would make available for private development up to six leases of public 011 shale lands of not more than 5,120 acres each. Two tracts are located in each of the States of Colorado, Utah, and Wyoming. $0 i 1$ shale development would produce both direct and indirect changes in the environment of the oil shale region in each of the three States where commercial quantities of oil shale resources exist. Impacts would include those on the land itself, on water resources and air quality, on fish and wildlife habitat, on grazing and agricultural activities, on recreation and aesthetic values, and on the existing social and economic patterns as well as others. The environmental impacts from both prototype development at a level of 250,000 barrels per day of shale oil and industry producing a possible 1 million barrels per day by 1985 are assessed for their anticipated direct, indirect and cumulative effects.

Volume I, Regional impacts of oil shale development. Volume I provides an assessment of the current state of oil shale technology and describes the regional environmental impact of oil shale development at a rate of one million barrels per day by 1985. (NTIS)

Volume II, Energy alternatives. Volume II considers the regional and cumulative aspects of a mature oil shale industry. (NTIS)

Volume III, Description of selected tracts and potential environmental impacts. Volume III examines the specific action under consideration. Its focus is on the specific environmental impacts of prototype development on public lands which, when combined, could support a production potential of about 250,000 barrels per day. (NTIS) 
Volume IV, Consultation and coordination with others. Volume IV describes the consultation and coordination with others in the preparation of the final statement, including comments received and the department's responses. (NTIS)

Volume $V$, Letters received during the review process. (NTIS)

Volume VI, Public hearings (oral testimony). (NTIS)

Everhert, W. H., and B. E. May. 1973. Effects of chemical variations in aquatic environments. Vol. 1. Biota and chemistry of Piceance Creek. U.S. Dept. of Commerce, $126 \mathrm{pp}$.

Sampling a small stream in the rich oil shale country of Northwestern Colorado confirmed distinct seasonal trends and habitat preference in invertebrate populations. Discharge was a major influence on invertebrates and chemical composition of the stream. Seasonal variations, biomass, and species composition of invertebrates appear characteristic of 011 shale area streams. (NTIS)

Fletcher, K. J., and M. F. Baldwin (ed.). 1973. A scientific and policy review of the prototype oil shale leasing program final environmental impact statement. Environmental Impact Assessment Project of Institute of Ecology, Washington, DC $197 \mathrm{pp}$.

The Environmental Impact Statement (EIS) for the proposed oil shale leasing program is deficient in significant respects, including the accuracy of the data, the extent of the analysis and the manner in which the material is presented.

The EIS fails to give thorough consideration to alternatives and their environmental impacts: available program alternatives are dismissed, despite environmental impacts that may be less severe than those of the proposed program; energy alternatives are neglected on the basis of incomplete information and unsubstantiated assumptions.

Data on environmental impacts of the events to be caused by oil shale development are not presented or analyzed systematically. Critical cause-effect relationships, such as the ecological changes which might result from anticipated reductions of wildlife, or the environmental impact of offsite power generation, water supply and transportation, were misunderstood and/or neglected by the authors of the EIS.

The EIS evidenced a recurring tendency to over-estimate the importance of the proposed program to beneficial ends (energy supply, economic gain) and to under-estimate its importance with respect to adverse impacts (environmental damage of many types). Conversely, alternatives are characterized with the reverse emphasis. 
Although large quantities of data are presented in the EIS, it lacks a balancing procedure by which decision-makers and the general public can weigh competing factors. Cost-benefit analysis, which can be a useful aid to such balancing, was not employed in the EIS.

The EIS neglects analysis of the environmental effects of potential conflicts posed by the proposed program with existing federal and state air and water pollution laws and suggests no measures to mitigate the many adverse impacts that can result from contradictions and legal loopholes in the program's lease form.

The EIS made no attempt to analyze the severe environmental changes likely from development of a mature $0 i 1$ shale industry despite implications that steps will be taken under the proposed shale program which may be practically and politically irreversible.

Despite its deficiencies, the EIS outlines clearly the immense magnitude of potential adverse environmental impacts of the proposed oil shale program. In this light alternative program design could be reconsidered and the lease redesigned as a mitigating factor.

Leythaeuser, D. 1973. Effects of weathering on organic matter in shales. Geochim. Cosmochim. Acta. 37: 113-120.

The most drastic changes of the organic geochemical parameters examined (organic carbon, soluble organic matter content and composition, $\delta C_{13}$ insoluble organic matter) occur over the near-surface $3 \mathrm{~m}$ intervals of two shallow core holes drilled into outcrops of the Upper Cretaceous Manos Shale in Utah. This observation is believed to reflect the effects of weathering under the semi-arid climate of the study area. Therefore, organic geochemical data obtained from analysis of surface samples should be interpreted with caution.

Magee, E. M., H. J. Hall, and G. M. Barga, Jr. 1973. Potential pollutants in fossil fuels. PB-225-039. (NTIS)

The report presents and analyzes data obtained from the literature on sulfur, nitrogen, and other potential pollutants in fossil fuels consumed in the United States. The data are categorized according to the location of the raw fuels, and are analyzed for geographic effects on composition. The trace element information available for coal is significantly greater than for 011 ; however, additional data are needed for both coal and $0 i 1$ on all potential pollutants in order to allow complete characterization of the pollution potential of a fuel. 
Nielsen, I. 1973. Low cost air-water pollution control chemicals from Colorado oil shale deposits. AIChE Symposium Ser. Water 69(129): 153-166.

The Colorado nahcolite-dawsonite-shale oil deposits can be utilized to give cheap air-water pollution control chemicals, petroleum, alumina, organic and inorganic chemicals, and little waste products. Nahcolite $\left(\mathrm{NaHCO}_{3}\right)$ will sufficiently remove $\mathrm{SO}_{2}$ from stack gas. Aluminate from dawsonite $\left[\mathrm{NaAI}(\mathrm{OD}) \mathrm{CO}_{3}\right]$ precipitates phosphates in sewage and provides clarification. Soda ash neutralizes and softens water.

0liver, W. B. i973. (Chairman) U.S. Energy Outlook. Water Availability. A report by the Water Availability Task Group of the Other Energy Resources Subcommittee of the National Petroleum Council's Committee on U.S. Energy Outlook. National Petroleum Council, 1625 K. Street N.W., Washington, DC 20006.

If the water supplies are to be available when needed to develop other energy resources as substitutes for petroleum, several national and interstate issues must be resolved because large volumes of water are required to convert coal and oil shale into useable electricity or synthetic hydrocarbon form. Water requirements for the western states are based on the "levels of energy resource development and unit water needs identified by the National Petroleum Council's Electricity Task Group, Coal Task Group and $0 i 1$ Shale Task Group.

An estimate of the available supply of water for industrial use has been compiled from studies prepared by federal, state and private agencies. While there are differences of opinion among experts, it is believed that this composite estimate is reasonably accurate. However, two limitations on the reliability of water supply projections should be recognized: 1) Physical availability is estimated from historical records, generally of limited time span and subject to long- and short-term climate trends; and 2) Legal availability is controlled by a complex body of water law based on interstate compacts, statutes and case law, and is subject to individual property rights created under state law.

For the critical basins of the Upper Colorado River and the Upper Missouri River, the Task Group concludes that there will be an adequate supply of water under present allocations to meet the requirements in all areas except Arizona and New Mexico. The problem of water quality can be expected to become more important in the arid western states as population, industrialization and energy production continue to grow. Assuming rigorous compliance with plant and municipal effluent standards, problems of stream quality deterioration may develop from diversion of natural flows which have historically diluted the natural "pollutants" (from mineral springs, agriculture return flow, etc.). 
Pitman, J. K., and J. R. Donnel1. 1973. Potential shale-0il resources of a stratigraphic sequence above the mahogany zone, Green River Formation, Piceance Creek Basin, Colorado. J. Research U.S. Geol. Surv. 1(4): 467-473.

In the southern part of the Piceance Creek basin the upper part of the Green River Formation above the Mahogany zone contains beds of rich $0 i 1$ shale which may be economically recoverable by the surface-mining operation. Four units within this sequence were evaluated for thickness, distribution, oil yield, and potential shale-0il resources. In the area appraised, total estimated resources of 128.6 billion bbl of 011 are contained within the sequence. It is thickest in T. 3S, R. 96W., where 354 feat of oil shale yields an average of 14 gallons of oil per ton, with a total resource of 9.0 billion bbl. It is richest in $T$. $5 \mathrm{~S} ., \mathrm{R} .96 \mathrm{~W}$., where 250 feet of oil shale yields an average of 19 galion of oil per ton, with a total resource of 6.5 billion bbl. Resources are tabulated for four units of the sequence. 10 refs. (NTIS)

Robinson, W. E., and Cook, G. L. 1973. Compositional variations of organic material from Green River oil shale. Wyoming No. 1 Core. U.S. Bur. Mines RI 7820, $32 \mathrm{pp}$.

0il-shale samples selected from a core of the Green River Basin (Wyoming) were studied to ascertain differences in the composition and/or chemical structure of the organic material in the samples relative to stratigraphic position within the Green River Formation. This involved a systematic study of the soluble organic material and the insoluble kerogen present in the samples. Emphasis was placed upon the distribution of the alkanes (normal and isoprenoid compounds) in the soluble extract and upon the aromaticity of the kerogen. In general, it was concluded that significant differences exist in the chemical structure of the oilshale organic material from various strata within the Green River Formation of Wyoming. Most of the compositional and structural changes were not related to burial depth but were related to source material variations, environmental differences, or other factors.

Schmeh1, W. R. and B. D. McCaslin. 1973. Some properties of spent oilshale significant to plant growth. Ecology and Reclamation of Devastated Land, 1: 27-42, Gordon and Breach, London.

Spent oil shales from two pilot plant operations were analyzed for chemical and physical properties which affect plant growth. Plantgrowth studies were then conducted on one of the spent shales in the greenhouse to determine treatments required to obtain normal plant growth. 
Chemical analysis of the spent shales revealed that the materials were highly saline, highly alkaline, and low in available phosphorus and nitrogen. There was very little growth of tal1 wheatgrass (Agropyron elongatum L.) and Russian wild ryegrass (Elymas junceus L.) in untreated shale. When the shale was mixed with soil in varying amounts, growth on a 50-50 0i1-tospent-shale mixture was still less than $10 \%$ of that on normal soil. When excessive soluble salts were removed from the spent shale by leaching with a low-salt water, normal plant growth could be obtained after fertilization with nitrogen and phosphorus.

Science Policy Research Division Staff, Library of Congress. 1973. Energy from oil shale: technical, environmental, economic, legislative, and policy aspects of an undeveloped energy source. Report from Library of Congress to House Subcommittee on Energy.

$0 i 1$ shale is one of the most abundant but undeveloped U.S. energy sources. High grade oil shales found in the Green River Formation in Colorado, Utah, and Wyoming contain the equivalent of 600 billion barrels of oil. Exploitation of this resource would supplement U.S. supply of liquid petroleum for many decades. The basic technology required to process this resource has been tested on a demonstration scale. The first U.S. commercial plant could be in operation by late 1976. Current economic analyses indicate that the processing of oil shale is within or near the range of economic feasibility. Environmental acceptability remains to be tested on a largescale basis. Advances in environmental control technologies, for example, revegetation and chemical processing of effluents, are said to reduce some of the harmful environmental impacts resulting from development of this resource.

The lag in large-scale exploitation of oil shale has been attributed to such factors as the leasing policies of the federally owned oil shale lands, lack of a national oil shale policy, large investment costs, uncertainty of return on investments, and current tax policies regarding oil shale development. The announcement of the Prototype $0 i 1$ Shale Leasing Program of the Department of the Interior is one of the first signs of an emerging national oil shale policy.

This paper discusses proposed legislation in the 93rd Congress concerned with the development of oil shale, for example, the Shale $0 i 1$ Development Corporation Act which would establish a cooperative government-industry corporation to construct models of an oil shale processing plant to demonstrate the economic feasibility and environmental acceptability of different technological methods, and, if deemed feasible, construct a commercialsized plant.

If the Congress decides that alternative action is necessary to stimulate directly or indirectly exploitation of this resource, possible considerations might include: 
1. Federal loans to private industry to encourage development of an oil shale industry;

2. An independent Government agency to exploit a portion of the federally-owned oil shale deposits;

3. A clearly defined national oil shale policy;

4. Tax policies to encourage private development; and

5. The stimulation of private exploitation of the oil shale resources through contract provisions.

Because of the known and unknown consequences of oil shale development, congressional actions seeking to stimulate the development of oil shale may have to be balanced by cautious concern for the environmental integrity of the oil shale lands.

Smith, R. H. 1973. Manufacture of low sulfur fuel oils from oil shale. AIChE Symposium Ser, 127(69): 98-99.

A processing scheme for producing oil from shale is presented. Mined and crushed raw shale $(66,000$ tons/day) is fed to retort where pyrolysis occurs. The vapors are fed to an oil recovery section where they are partially condensed and fractionated. The remaining vapors are sent to a gas recovery plant where naphtha is removed. Gas is treated for acid gas removal and used for plant fuel. Hydrogen sulfide in the acid gas is converted to sulfur in a Claus unit. Naphtha and heavy gas $0 i 1$ fractions are combined to produce a $\mathrm{C}_{4}+$ shale $0 i 1$. (NTIS) 
Cook, G. L. 1972. 0il shale - an impending energy source. J. Petroleum Technology 4: 1324-1330.

Recent political, technological, and economic developments lead to optimism for the commercial exploitation of oil shale as a source of energy. Although presently the production of oil by mining or aboveground retorting seems feasible, the production of oil by in-situ techniques or of pipeline gas by either aboveground or underground gasification is less probable for a while.

Foster, J. I., and W. E. Robinson. 1972. 0xygen functional groups in Green River oil shale kerogen and trona acids. Coal Sci. 55: 222-231.

Carboxy 1, ester, amide, hydroxy1, aldehyde, and ketone groups were estimated for oil-shale kerogen and kerogen-derived trona acids from the Green River Formation. Ether groups were estimated by difference. Carboxyl, ester, and ether groups were found to account for the major portion of the oxygen in both the kerogen and trona acid samples. Minor amounts of amide, hydroxyl, aldehyde, and ketone groups were indicated. The reactive oxygen groups, carboxyl and ester, account for about one-half of the total oxygen in kerogen and two-thirds of the total oxygen in trona acids while the unreactive ether group accounts for the other half of the total oxygen in kerogen and one-third of the total oxygen in trona acids.

Herkenhoff, E. C. 1972. When are we going to mine oil? Eng. Min. J. $173(6): 132-138$.

Mining the 383 known shallow oil fields in the U.S. is a practical way to increase oil production to meet the growing U.S. energy crisis. These oil fields are merely down-dip extensions of bituminous rock deposits, actually outcropping. They have an average depth of less than $500 \mathrm{ft}$. With such deposits, the stripping ratio and the cost of exposing and mining the oil-bearing strata would be low.

Howe, C. W., J. F. Kreider, and B. Udis. 1972. An economic analysis of the pollution problems in the Colorado River Basin: The upper main stem sub-basin. U.S. Dept of Commerce. COM-74-11311. (NTIS)

The purpose of this study is to develop a set of compatible models relating the economic activities of the sub-basins of the Colorado River, both present and prospective, to air quality and water quantity and quality resulting from these patterns of economic activity. This model will permit the planner to test some of the environmental implication of alternative growth patterns for the region. This study describes in detail the models which have been developed and calibrated for the 
Upper Main Stem sub-basin, an area which contains the origins of the most pressing problems of the Basin: salinity, shale oil industry future impacts, and expanded diversions to the Rocky Mountain Eastern s lope. (NTIS)

National Petroleum Council Staff. 1972. Committee on United States energy outlook. Other energy resources subcommittee. $0 i 1$ Shale Task Group. National Petroleum Council, Washington D.C. $125 \mathrm{pp.}$

Synthetic crude petroleum from oil shale does have potential during the period 1971-1985 which, given the size and trend of energy needs, is worth careful consideration. However, under the conditions presumed to exist for the initial appraisal, the projected utilization of this resource is limited to $100 \mathrm{MB} / \mathrm{CD}$ by 1975 , even though there are 20 billion barrels of recoverable oil shale reserves having primary commercial attraction.

Poulson, R. E., H. B. Jensen, J. J. Duva11, F. L. Harris, and J. R. Morandi. 1972. Determination of compound types in complex mixtures using subtraction and gas chromatographic readout. Analys is Instrumentation 10: 193-201.

The need for improved compound-type analyses of shale-oil fractions resulting from the lack of specificity of chromatographic adsorbents or from the poor precision of the methods of quantitation is discussed.

A subtractive analytical technique using a gas chromatograph (g.c.) readout step is illustrated for several compound types found in shale oils. This method consists of adding an appropriate internal standard to the sample, applying a specific subtractive technique, and determining the amount of a compound type from comparison of the before and after gas chromatograms. The method is applied to hydrocarbon types (alkane-alkene-aromatic) and polar materials including acids and bases. The presence of an internal standard throughout the material handling steps eliminates such precision-degrading operations as quantitative separation of phases and solvent removal so that a wide variety of chemical characterization methods become feasible. In many cases a test that is more definitive for a given purpose may be devised because of the flexibility added by gas chromatographic readout. 0il samples of $0.1 \mathrm{ml}$ are readily handled with the method.

The precision and detection limits are set by the precision of the gas chromatographic readout at about $\pm 1 \%$, which is a great improvement over presently used routine methods. Although the subtractive technique with g.c. readout is not useful for trace analyses, the greater reliability of the data for compound types present in shale oil at the few percent level allows use of the method for more detailed characterization of polar materials by comparing results from use of a multiplicity of polar-subtractive agents as well as correlation with independent methods such as nonaqueous potentio-metric titration. 
Routson, R. C., J. A. Kittrick, and E. H. Hope. 1972. Interlayer hydration and the broadening of the $10 \AA$. X-ray peak in illite. Soil Sci. 113(3): 167-174.

This study has shown that $10-\AA$-ray peak broading 111 te is in part due to reversible interlayer hydration. During heating to $300^{\circ} \mathrm{C} \mathrm{K}$ saturated 111 ites dehydrated gradual1y, whereas Cs-saturated 111 ites contracted suddenly at lower temperatures. The water reversibly released from $\mathrm{K}$-saturated $i 11 \mathrm{ite}$ at low temperatures is considered to be physically entrapped due to closure of dehydrated edges. Hightemperature water in illite in excess of that predicted from the muscovite formula may also be physically entrapped.

Silver, H. F., N. H. Wang, H. B. Jensen and R. E. Poulson. 1972. Denitrification reactions in shale oil gas. Sym. on advances in distillate and residue oil technology. Am. Chem. Soc., Div. Pet. Chem. Preprint 16(1): G94-100.

Types of nitrogen compounds found in the liquid produced during the hydrogenation of shale gas oil over a $\mathrm{Co}-\mathrm{Mo}_{0}$ on $\mathrm{Al}_{2} \mathrm{O}_{3}$ catalyst have been analyzed by means of a combined nonaqueous potentiometric titration-infrared analysis technique. The applicability of this technique to this work was demonstrated by analyzing both mixtures of pure nitrogen compounds and pure nitrogen compounds added to shale gas $0 i 1$.

Results of the data obtained in this work can be used to define the mechanisms by which the predominantly aromatic-type nitrogen compounds in shale gas oil are denitrified. The first step in the denitrification reaction is hydrogenation of the nitrogen-containing rings, second step is the rupture of the saturated rings to form amines, and the final step is decomposition of the amines to form ammonia. At a reaction temperature of $600^{\circ} \mathrm{F}$, the buildup of tetrahydroquinolines is evidence that saturated-ring rupture appears to be the rate-limiting reaction. On the other hand, at a reaction temperature of $825^{\circ} \mathrm{F}$, the rate of the hydrogenation reaction appears to 1 imit the rate of the denitrification of shale gas 011 , even at the relatively high hydrogen partial pressures used in this study. These hydrogen partial pressures are much higher than those generally used to denitrify petroleum feed stocks.

A1 though indole-type compounds appear to decompose at a faster rate than quinoline-type compounds, the differences in these two rates are not as large as might be expected from other researchers' pure-compound studies.

Steel, G., and W. Henderson. 1972. Isolation and characterization of stanols from the Green River shale. Nature 238: 148-150.

We have recently reported the isolation of a triterpenoid alcohol, tetrahymanol, from the Green River Shale (60 × $10^{6} \mathrm{yr}$ old) together 
with a complex mixture of unidentified polycyclic alcohols. Further investigation of this mixture has revealed the presence of a series of stanols and saturated triterpenoid alcohols in the carbon number range $\mathrm{C}_{27}-\mathrm{C}_{30}$. We now report the characterization of several of the stanols from this extract.

Ward, J. C., and S. E. Reinecke. 1972. Water pollution potential of snowfall on spent oil shale residues. Environmental Engineering Program, Dept. of Civil Engineering, Colorado State University, Fort Collins, Co 80521 .

Concentration and composition of total dissolved solids were determined in both surface runoff water and in water which had percolated through a bed of the residue. An empirical equation was developed to predict the concentration of the runoff water as a function of independent parameters. A tendency for saturation of the residue to occur during a period of snowmelt was revealed. The effects of this saturation on the residue were also considered.

An overland flow water quality model was developed and successfully applied to runoff resulting from rainfall and snowfall on $0 i 1$ shale retorting residue. The surface water runoff from snowfall on oil shale residue has less water pollution potential than the runoff from rainfall.

It was shown that the concentration of dissolved solids in the runoff was a function of the cumulative volume of runoff per unit width, the porosity of the oil shale retorting residue, the soil moisture content, and the snowmelt rate, and the fraction of the snowmelt water that appears as runoff.

Wethington, J. A., Jr. 1972. An investigation of tritium decontamination. Final Report, University of Florida, Gainsville, FL.

The stimulation of gas wells by nuclear explosions produces tritium ( $T$ ) containing gas and water. Exchange reaction can be used to decontaminate these materials. The $\mathrm{T}$-content of $\mathrm{H}_{2} \mathrm{O}$ was reduced by contact with certain sandstones, shales, and clays. Exposure was at room temperature or at elevated temperature, contact with other sandstones, etc. resulted in little decontamination. No exchange between HTO and $\mathrm{CH}_{4}$ was observed up to $300^{\circ} \mathrm{C}$ unless a catalyst was present. Certain rocks were found to have intrinsic catalyst activity. Rhodium on alumina, Pt on alumina, Wilkinson's catalyst, $\mathrm{Pt}+2$, and $\mathrm{Pt}+4$ were all excellent exchange catalysts.

Because of current interest in the Rio Blanco experiment, a sandstone and a shale from the site were tried. The T-content of water was not reduced, and the samples showed no catalytic activity for the exchange reaction. 
Zambas, P. G., G. R. Haworth, F. W. Brackebusch, and J. B. Sellers. 1972. Large scale experimentation in oil shale. Trans. Soc. Mining Eng. 252(3): 283-289.

Results of large-scale mining experimentation carried on in Stage II of the Anvil Points $0 i 1$ Shale Research Program, Rifle, Colorado, are reported. After a new adit was excavated, over 500,000 tons of $0 i 1$ shale was extracted during a 13-month period by a modified room and pillar method. Experiments in drilling and blasting headings, benches, and crosscuts are reported. Roof-bolting procedures, loading and hauling and ventilation design are discussed. Results of the extensive investigations carried out by the cooperative industry group and earlier work by the U.S. Bureau of Mines indicate that mining oil shale is technologically feasible. 
Gelpi, E., P. C, Wszolek, E. Yang, and A. L. Burlingame. 1971. Milligram scale automatic preparative GLC of the steranes and triterpanes isolated from Green River Formation oil shale. Am. Chem. Soc., Div. Fuel Chem. 15(1): 102-112.

The isolation of relatively large quantities of each one of the steranes and triterpanes from the Green River Shale bitumens with this sytem will enable us to undertake a full study of their molecular structures. The data obtained so far indicates that with proper consideration of the basic parameters of the chromatographic process it becomes possible not only to separate very complex mixtures, but also to collect each component on an individual basis and in high purities for further study. Thus, is appears that if analytical specifications can be incorporated into a standard preparative system, new ways will be open in the field of natural product analysis toward the isolation of the significant components within any given mixture. The manufacturers of the existing preparative systems should give some attention to the many chemists handling mixtures that simply cannot be resolved on standard preparative gas chromatographs. These kinds of problems, similar to the one discussed here, will ultimately call for reliable automatic units with injection systems capable of going down to the $1 \mu \mathrm{g}$ level or less and with efficient trapping systems for collection of submili igram amounts.

Henderson, W., and G. Stee1. 1971. Isolation and characterization of a triterpenoid alcohol from the Green River Shale. J. Chem. Soc. (D)21: $1331-1332$.

A triterpenoid alcohol (tetrahymanol) has been isolated and characterized from the Green River Shale (60 million years) by means of GLC, TLC and mass spectra.

Hubbard, A. B. 1971. Method for reclaiming waste water from oil-shale processing. Am. Chem. Soc., Div. Fuel Chem. Preprint 15(1): 21-24.

The components of waste water produced by processing Colorado and Wyoming oil shale are organic and inorganic in nature. The organic material is a complex mixture of amines, acids, bases, and neutral compounds. The major inorganic components include ammonium, sodium, chloride, bicarbonate, carbonate, and sulfate ions. The procedure for reclaiming the waste water from oil-shale processing described in this paper successively removes the components stepwise so that the effiuent from any step can be diverted for plant use where further purification may not be necessary. The method involves (1) treating the water with 1 ime and heating to remove carbonates, most of the ammonia, and some of the organic material, (2) pass over activated carbon to remove the balance of the dissolved organic material, (3) pass over a cation exchange resin to remove the cations and (4) pass over an anion exchange 
resin to remove the anions. Waste waters produced by in situ retorting of oil shale and a gas combustion retort were reclaimed sufficiently to meet the permissible surface water criteria for public water supplies established by the Federal Water Quality Control Administration and for irrigation use.

Hutchins, J. S., W. W. Krech, and M. W. Legatski. 1971. Environmental aspects of a commercial oil shale operation. In: Proceedings of the Environmental Quality Conference for the Extractive Industries of the American Institute of Mining, Metallurgical, and Petroleum Engineers, Inc. Washington, DC June 7-9, 1971.

Colony Development Operation, a joint venture of several oil and mineral producers with Atlantic Richfield Co. as operator, is currently engaged in a 17 million dollar field program to investigate the feasibility of shale oil production on a commercial scale, that would produce in excess of 50,000 tpd of processed shale. Paper discusses the title problem in respect to - disposal of processed shale, impact of operation on vegetation, air quality and water quality. 2 refs. (NTIS)

Poulson, R. E., H. B. Jensen, and G. L. Cook. 1971. Nitrogen bases in a shale-oil light distillate. Am. Chem. Soc, Div. Pet. Chem. Preprint 16(1): A49-A55.

The chemical characterization of shale oil is important in planning for its potential use as an energy or as a chemical source. The polar materials in shale oil are of particular interest because they cause problems in refining and also in themselves form a potential source of chemical raw materials.

The naptha fraction of a shale $0 i 1$ has been described in detail, but it is a small part of the crude oil. The nitrogen compounds in a heavy distillate have been characterized in terms of model compounds. The composition of the light distillate, which is not readily interpolated from these two fractions, has not been reported before. In a closely related area, detailed compositional studies of the nitrogen and oxygen compound types in petroleum have been reported by Snyder, et al.

The objective of this investigation was to characterize the nitrogentype compounds in a shale-0il light distillate $\left(190^{\circ}-310^{\circ} \mathrm{C}\right)$. The light distillate comprises $15 \%$ of the crude shale 011 and has as much as $20 \%$ nitrogen-containing compounds. Over $90 \%$ of the nitrogen in the light distillate is titratable as either weak bases $\left(\mathrm{pK}_{\mathrm{a}}=+2\right.$ to +8$)$ or as very weak bases $\left(\mathrm{pK}_{\mathrm{a}}=-2\right.$ to +2$)$.

Cation-exchange fractionation was used as a separative tool to fractionate a weak-base fraction and four very weak-base fractions from the light distillate. These fractions were examined using titrations and various specific chemical and spectrometric methods to determine the nitrogen types in each fraction. 
Poulson, R. E. and H. B. Jensen. 1971. Problems in analys is of wide boiling range materials using a gas liquid chromatography - flame ionization detector system. Jour. of Chromatographic Sci. 9: 300-306.

The Bureau of Mines investigated the sources of error of a GLC-FID system in quantitative analysis of wide-boiling-range mixtures such as are encountered in simulated distillation of crude shale oil or petroleum. The sample-introduction system, column effects, and the FID itself were studied using normal alkanes as a diagnostic aid. The on-column inlet technique of sample introduction is compared with the flash-vaporization inlet technique. Column-adsorption effects and the use of tail-reducing materials are discussed. Problems with the FID relating to insulator and electrode contamination, electrode emissivity, sample capacity, and burner design are illustrated and discussed. Normal alkane FID response relative to $n$-heptane over the $C_{7}-C_{32}$ range is shown to be $1.00 \pm 0.03$ for a parallel-plate FID when operating normal.

Robinson, W. E. and G. L. Cook. 1971. Compositional variations of the organic material of Green River oil shale - Colorado No. 1 core. PB-198-824. (NTIS)

Sixty samples, selected from a 2,300-foot core of the Green River Formation in Colorado, were studied to ascertain differences in the structure of the organic material present in the oil shale samples. Emphasis was placed upon relating differences in the aromatic content of the insoluble kerogen and the alkane content of the extractable material obtained from the selected samples. The methods used in determining these differences consisted of fractionation of the soluble material, carbon and hydrogen analysis, volatile material determination, carbon residue determination, oxidation rate determination, and infrared analysis. In general, it was concluded that the organic material in this core does vary in chemical structure and that some of these variations resulted from factors related to depth of burial. Other observed changes in structure of the organic material were not depth-dependent and resulted from other factors such as source material variations, biological alterations, or ecological differences.

Ruark, J. R., H.W. Sohns and H. C. Carpenter. 1971. Gas combustion retorting of oil shale under anvil points lease agreement: Stage II. U.S. Bur. of Mines RI 7540, $74 \mathrm{pp}$.

This report presents results of the research and development work and operations performed during stage II of the gas combustion retorting research program conducted by the Colorado School of Mines Research Foundation and six major oil companies at the Bureau of Mines Anvil Points Research Facilities. The experimental program, including retort modification and air-gas distribution development, effects of shale quality and particle-size distribution, and other variables on the process, is discussed. 
Although operating problems are not fully resolved, it appears that the gas combustion retorting process can be successfully applied to achieve oil yields in excess of 85 percent of Fischer assay at mass shale feed rates of 500 pounds per hour per square foot of cross-sectional bed area, approximately twice the rate previously demonstrated to be reasonably practicable.

Ward, J. C., G. A. Margheim and G. 0. G. Löf. 1971. Water pollution potential of rainfall on spent oil shale residues. Water Pollution Control Research Series, Water Quality Office, EPA. GPO, Washington, DC 116 pp.

Physical properties, including porosity, permeability, particle size distribution, and density of spent shale from three different retorting operations, (TOSCO, USBM, and UOC) have been determined. Slurry experiments were conducted on each of the spent shales and the slurry analyzed for leachable dissolved solids. Percolation experiments were conducted on the TOSCO spent shale and the quantities of dissolved solids leachable determined. The concentrations of the various ionic species in the initial leachate from the column were high. The major constituents, $\mathrm{SO}_{4}=$ and $\mathrm{Na}^{+}$, were present in concentrations of 90,000 and $35,000 \mathrm{mg} / 1$ in the initial leachate; however the succeeding concentrations dropped markedly during the course of the experiment. A computer program was utilized to predict equilibrium concentrations in the leachate from the column. The extent of leaching and erosion of spent shale, and the composition and concentration of natural drainage from spent shale has been determined using oil shale residue and simulated rainfall.

Concentrations in the runoff from the spent shale have been correlated with runoff rate, precipitation intensity, flow depth, application time, slope, and water temperature.

\section{0}

Arnold, W. D. and D. J. Crouse. 1970. Radioactive contamination of oil produced from nuclear-broken shale. In: Proceeding of Symposium on Engineering with Nuclear Explosives. CONF-700101, 2: 1597-1612.

The results of small-scale exposure and retorting tests indicate that oil recovered from shale that has been broken with nuclear explosives will be contaminated with tritium. When oil shale was heated in sealed flasks with tritiated water vapor or with tritiated hydrogen, both the shale and the oil subsequently retorted from the shale contained tritium. There was much less contamination of the shale or oil, however, when the shale was exposed to tritiated methane and ethane. Contamination of shale and oil with tritium, as the result of exposure to tritiated water, increased as the exposure temperature, exposure pressure, and the tritium concentration in the water were increased. This contamination also increased as the exposure time was increased up to 25 days, but not significantly thereafter. More than $90 \%$ of the tritium was removed from contaminated 
shale by treating the shale with moist air at elevated temperatures. Only small amounts of the tritium were removed from crude oil by contacting it with solid drying agents or with water. When tritium-contaminated shale oil was distilled, the tritium contents of the recovered fractions were found to be approximately equal.

After being heated with a sample of underground test-shot debris, liquid shale oil became contaminated with radioactive fission products. Most of the radioactivity of the oil was due to finely dispersed solids rather than to dissolved radionuclides. Filtration of the oil removed a major fraction of the radioactive material. When the contaminated oil was distilled, more than $99 \%$ of the radionuclides remained in the pot residue.

Baker, J. M. 1970. The effects of oils on plants. Environ. Pollut. 1: 2744.

0ils vary in their toxicity according to the content of low-boiling compounds, unsaturated compounds, aromatics, and acids. The higher the concentration of these constituents, the more toxic the oil. After penetrating into a plant, the oil may travel in the intercellular spaces and possibly also in the vascular system. Cell membranes are damaged by penetration of hydrocarbon molecules, leading to leakage of cell contents, and oil may enter the cells. 0ils reduce transpiration rate, probably by blocking stomata and intercellular spaces. This may also be the reason for the reduction of photosynthesis which occurs, though there are other possible explanations of this - such as disruption of chloroplast membranes and inhibition caused by accumulation of end-products. The effects of oils on respiration are variable, but an increase of respiration rate often occurs, possibly due to mitochondrial damage resulting in an "uncoupling" effect. 0ils inhibit translocation probably by physical interference. The severity of the above effects depends on the constituents and amount of the $0 i 1$, on the environmental conditions, and on the species of plant involved.

Blumer, M., and M. Rudrum. 1970. High Molecular weight fossil porphyrines. Evidence for monomeric and dimeric tetrapyrroles of about 1100 molecular weight. J. Inst. Petro1. 57(548): 99-106.

Vanadyl porphyrin complexes of approximately 1100 molecular weight have been isolated from a Triassic and a Pennsylvanian oil shale by gel permeation chromatography. Adsorption chromatography resolved the pigments into two different structural types. The chromatographic behavior, as well as visible, infrared, and mass spectra, suggest that the less polar group of pigments consists of several homologous series of tetrapyrrol ring monomers with long chain alkyl substitution. The more polar pigments are homologous porphyrin dimers. The geochemical implications and possible application of these findings are discussed. 10 refs. (NTIS) 
Brown, K. B., P. G. Earnshaw, F. R. McDonald, and H. B. Jensen. 1970. Gas-liquid chromatographic separation and spectrometric identification of nitrogen bases in hydrocracked shale oil naphtha. Anal. Chem. 42(2): 146-151.

A tar-base concentrate from a hydrocracked shale oil naphtha was separated by gas-liquid partition chromatography using nonpolar and polar columns. Final cuts were analyzed by mass, infrared, and nuclear magnetic resonance spectrometry. Fifty individual compounds were identified and eight additional structures are proposed as possible components of the concentrate. Alkylpyridines comprised about $64 \%$ of the bases and alkylanilines about $33 \%$; the rest of the bases were quinoline and small quantities of cycloalkanopyridines. Substitution patterns for both the alkylpyridines and alkylanilines showed that a substitution was favored over $B$ or $Y$, and $Y$ was favored over $B$.

Culbertson, W. J., Jr., T. D. Nevens, and R. D. Hollingshead. 1970. Disposal of oil shale ash. Colo. Sch. Mines Quart. 65(4): 89-132.

Covers the subject's cemented and uncemented properties, cementation chemistry, measurements of cohesive hydratis, and leaching of shale ashes.

Nevens, T. D., W. I. Culbertson, Jr. and R. D. Hollingshead. 1970. Disposal and uses of oil ash. Denver Research Institute, $101 \mathrm{pp}$. PB-234-208. (NTIS)

This study was initiated to determine some of the properties of waste shale ash. General studies dealing with a variety of Piceance Creek shales retorted and burned for various times and temperatures were made. One objective of this approach was to define as nearly as possible the best conditions for processing shale ash before it is dumped in order to obtain a well stabilized dump least subject to wind and water erosion and land slides. In the studies two approaches were as follows: (1) physical strength studies of shale ash as a function of a number of variables and (2) chemical studies as a function of these variables in order to define the cementing components in the hydration products of shale ash. The variables studied included: (a) comp. of shale ash, (b) burning temp., (c) burning time, (d) moisture content, (e) degree of compaction, ( $f$ ) storage time and $(\mathrm{g})$ storage temp.

Determination of cohesive hydrates $\mathrm{Ca}(\mathrm{OH})_{2}, \mathrm{CaAl}_{3} \mathrm{H}_{2} \mathrm{O}$, sulfoaluminate etc. by differential thermal analysis (DTA) or differential scanning colorimeter (DSC)

$\underline{1969}$

Bae, J. H. 1969. Some effects of pressure on oil-shale retorting. Soc. Petroleum Eng. J. 9(3): 287-292. 
Series of batch-type retorting experiments at $930^{\circ} \mathrm{F}$ were performed to investigate the effect of pressure and surrounding atmosphere on the retorting of oil shale. The experimental pressure ranged from atmospheric to 2500 psig. The sweeping gases used were $\mathrm{N}_{2}, \mathrm{CO}_{2}, \mathrm{H}_{2}, \mathrm{NH}_{3}$ and $\mathrm{H}_{2}$. High pressure reduces the oil yield significantly and produces a larger volume of light hydrocarbon gases. Sulfur and nitrogen content in shale oil does not change significantly with increasing pressure. The effect of sweeping gas is usually smal1. 10 refs. (NTIS)

Hand, J. W. 1969. Planning for disposal of $0 i 1$ shale, chemical and mine wastes. Colo. Geol. Survey, Special Pub. 1: 33-38.

The author thinks industry should do the requisite research on disposal of wastes.

Lovering, T. G. 1969. Distribution of minor elements in samples of biotite from igneous rocks. Geological Survey Research 1969, 650 B, p. B101-B106.

Two hundred samples of biotite taken from several types of igneous rocks from many localities have been analyzed by a semiquantitative spectrographic method in the laboratories of the U.S. Geological Survey.

Thirty-six minor elements were detected in one or more of these samples. $\mathrm{Ca}, \mathrm{Na}, \mathrm{Ti}, \mathrm{Mn}, \mathrm{Ba}, \mathrm{Co}, \mathrm{Cr}, \mathrm{Cu}, \mathrm{V}, \mathrm{Sc}, \mathrm{Ni}$, and $\mathrm{Sr}$ were detected in more than 90 percent of the samples. Biotite samples from different parent rock types show corresponding differences in concentrations of minor elements. Biotite from granitic pegmatite and pyroclastic rocks contains detectable Mo, and biotite from syenite and nepheline syenite commonly contains Ag.

Poulson, R. E. 1969. Stationary phase for separation of basic and nonbasic nitrogen compounds or hydrocarbons by gas-1iquid chromatography. J. Chromatographic Science 1: 152-157.

Retention data and bleed rates have been measured for some relatively stable liquid phases to obtain operational limits for gas-liquid chromatographic separation of polar shale-0il concentrates with boiling points above $200^{\circ} \mathrm{C}$. Gas chromatographic separation of polar compounds with boiling points over $400^{\circ} \mathrm{C}$ in quantities adequate for special identification may be accomplished on packed columns with efficiencies near 5000 theoretical plates and with less than one percent column bleed contamination.

Relative retention values were determined for some basic and nonbasic nitrogen compounds, and some hydrocarbons on polyethylene glycol (Carbowax 2OM), polyethylene glycol terminated with terephthal ic acid (Carbowax 20M-TPA), octylphenoxypolyethoxy ethanol (Triton X-305), and purified Apiezon $L$ doped with Carbowax 20M-TPA. Retention data were obtained at $180^{\circ}$ and $220^{\circ} \mathrm{C}$ on the polar liquid phases. Triton $\mathrm{X}-305$ was found to show more alkyl character than Carbowax 20M. 
Column bleed rates were measured with five percent liquid phase at $220^{\circ} \mathrm{C}$, the maximum temperature found appropriate for extended use of the polar columns. The Carbowax $20 \mathrm{M}$ bleed rate was $0.10 \mu \mathrm{g}$ hydrocarbon-equivalent/min with very slightly less for the Carbowax 20M-TPA, while the Apiezon L rate was $0.01 \mu \mathrm{g} / \mathrm{min}$, all at $73 \mathrm{ml} / \mathrm{min}\left(25^{\circ} \mathrm{C}, 1 \mathrm{~atm}\right)$ flow rate. An Apiezon $L$ column doped with five percent Carbowax $20 M$ to reduce tailing exhibited a bleed rate characteristic of Carbowax $20 \mathrm{M}$.

Hydrogen flame response factors were determined for several heterocyclic nitrogen compounds. By the agreement of hydrogen flame response factors for samples put through polar and nonpolar columns it was concluded that the polar columns do not destroy the relatively unstable indole-type nitrogen compounds although they are strongly retained.

Robinson, W. E. 1969. Isolation procedures for kerogens and associated soluble organic materials. In: Organic Geochemistry, G. Eglinton and M. T. J. Murphy (ed.). pp. 181-195. Springer-Verlag, NY.

Kerogens are of geochemical interest because they represent one of the most abundant forms of carbonaceous materials. The term "kerogen", or "oil-former," was originally given to the organic matter in oil shales, torbanite, kukersite, and others. Recently, broader usage has been made of the term in describing the insoluble organic material present in nonreservoir sedimentary rocks and other rocks. The soluble organic materials associated with oil-shale kerogens are of particular interest because they are usually indigenous to the formation and have had little opportunity for migration because of the low porosity and low permeability of the formations.

Down and Himus published a classification of shales and coals based upon a number of properties including the yield of oil on distillation. By this classification, the term "kerogen rocks" describes sedimentary deposits containing insoluble organic kerogen which on distillation yields on oil equivalent to more than 50 percent of the organic content of the rock. Similarly, the term "kerogen coals" describes sedimentary materials containing organic matter which upon distillation yields an oil equivalent to more than 10 percent and less than 50 percent of the organic content.

In the present discussion, the term "kerogen" will be used to describe the insoluble organic material present in kerogen rocks. The term "bitumen" will be used to describe the soluble organic material present in the kerogen rock based upon solubility in a hydrocarbon solvent. Other nomenclature will be self-explanatory. For example, the material solubilized by methanol will be referred to as "methanol-soluble material".

The discussion covers the isolation of kerogen, bitumen, fatty acids, porphyrins, amino acids, and carbohydrates from kerogen rocks. The procedures as described are intended to be informative without any implication of recommended usage. Other methods are applicable and in some 
circumstances may be preferred. Likewise, the articles reviewed were chosen for the subject matter discussed and no attempt has been made to completely review the subject.

\section{8}

Carpenter, H. C., and H. W. Sohns. 1968. Application of aboveground retorting variables to in situ oil shale processing. Colo. Sch. Mines Quart. 63(4): 71-82.

Retorting a chimney created by a nuclear explosion in oil shale should be technically feasible. Experience with the Laramie 10-ton retort shows that yields of 80 percent of Fischer assay can be attained when retorting oil-shale particles varying from small grains to pieces as large as 20 inches in 2 dimensions. As much as one-third of the available energy was lost through the sides and ends of the aboveground retort. Recovery of these losses and the more efficient utilization of sensible heat that will be possible in the large chimney resulting from a nuclear explosion should reduce air requirements to less than 10,000 scf per ton. Some carbonaceous residue in the spent shale may not be readily available for fuel; however, more efficient use of the energy that is available will reduce the fuel requirements.

Statistical evaluation of data obtained from the aboveground retort indicates that oil yield is influenced mainly by recycle gas rate, shale bed temperature, and grade of shale.

Carpenter, H. C., S. S. Tihen, and H. W. Sohns. 1968. Retorting ungraded oil shale as related to in situ processing. Am. Chem. Soc, Div. Pet. Chem. 13(2): F50-F57.

Retorting oil shale ungraded as to size and oil content such as might be expected in a nuclear chimney is technically feasible. Yields as high as 80 percent of Fischer assay have been obtained by retorting ungraded shales with a maximum particle size of 20 inches in two dimensions.

The oils produced from these ungraded oil shale charges are similar to oils produced by other internally heated retorts but they tend to have more desirable properties. Their API gravities are higher, and their pour points and viscosities are lower. These more desirable properties are advantageous for transporting the oils or for further processing.

Sufficient carbonaceous material remains on the spent shale to furnish the energy requirements of the retorting process; however, in the larger particles this material may not be readily available for fuel. Air requirements for the experimental work varied widely.

Cook, G. L., H. B. Jensen, and G. U. Dinneen. 1968. The composition of Green River shale oils. Presentation at the U.N. Symposium on Development and Utilization of $0 i 1$ Shale Resources, U.S.S.R. $26 \mathrm{pp}$. 
The physical properties and gross compositions of several shale oils produced by retorting Colorado's Green River Formation oil shale are compared using data obtained by a standardized distillation analysis method. Although specialized retorting techniques can be used to vary the oil properties, the usual shale oil is a viscous, high-pour-point oil containing large quantities of nitrogen, sulfur, and oxygen-containing compounds. It consists of small quantities of naphtha, larger quantities of distillate fuel, and often 50 percent distillation residuum. Detailed compositions of several naphthas have been published. The information is summarized for this report. Results of research, currently underway, into the composition of the distillates boiling above $200^{\circ} \mathrm{C}$ are also summarized indicating gaps that require further work to fully characterize the fractions.

Ely, N. 1968. The oil shale industry's water problems. J. Petroleum Tech. $20(3): 237-240$.

This paper presents an analysis of the water budget of the oil shale industry in Colorado. Particular reference is given to restrictions on supply imposed by the Mexican Water Treaty and interstate compacts, and by commitments already made against that restricted supply. It is concluded that the uncommitted residue will be inadequate for the oil shale industry's projected requirements, and must be supplemented by acquisition of existing water rights and curtailment of competing uses.

Mock, H. B. 1968. The role of the public land law review commission in solving oil shale problems. In: Fifth Symposium on 0il Shale. Colo. Sch. Mines Quart., 63(4):1-15.

A discussion of the role of the Colorado Public Land Law Review Commission in solving oil shale problems.

Montgomery, D. P. 1968. Refining of pyrolytic shale oil. Ind. and Eng. Chem., Product Research and Dev. 7(4): 274-282.

A pyrolytic shale oil was refined into marketable products to determine the severity of hydrodenitrogenation needed for sustained refining and the yields and qualities of the refined products. The refining steps were: delayed coking, with recycle of heavy coker distillate; hydrodenitrogenation of coker distillate, followed by fractionation; further hydrodenitrogenation of naphtha; reforming of nitrogen-free naphtha; catalytic cracking of gas $0 i 1$ from the hydrodenitrogenated coker distillate. Temperature and pressure maximums of $950^{\circ} \mathrm{F}$ and $1500 \mathrm{psig}$ were well within the scope of current refinery practice. Nitrogen content of the reformer feedstock was $1.5 \mathrm{ppm}$, and that of the cracking stock was $100 \mathrm{ppm}$ (basic); thus, both were adequately free of nitrogen to ensure long catalyst life. Reformates and catalytic gasolines of 98 octane 
number were produced. The hydrodenitrogenated coker distillate yielded a large volume of specification grade diesel fuel. Yields and product distributions for each refining step were determined, along with properties of the finished liquids.

Schlinger, W. G., and D. R. Jesse. 1968. Hydrotorting oil shale. Ind. and Eng. Chem., Process Design and Dev. 7(2):275-277.

Experimental results using hydrogen as a retorting fluid for recovery of shale oil from Rocky Mountain oil shales are presented. Using hydrogen at pressures between 1000 and 2000 psig and at temperatures between $900^{\circ}$ and $1000^{\circ} \mathrm{F}$, shale $0 i 1$ yields ranging up to 115 vol. \% of Fischer assay are obtained. Properties of both the shale $0 i 1$ and spent shale resulting from the hydrogen treatment or hydrotorting are discussed.

Smith J. W., L. G. Trude11, and K. E. Stanfield. 1968. Characteristics of Green River Formation oil shales at Bureau of Mines Wyoming corehole no. 1. U.S. Bur. Mines RI 7172, 89 pp.

The Bureau of Mines drilled Wyoming Corehole No. 1 in Sweetwater County, Wyoming, to sample Green River Formation oil shale. Core obtained was assayed for oil yield to determine richness and stratigraphic distribution of $0 i 1$ shale in the deposit. $0 i 1$ shale in place at Wyoming No. 1 site represents over 200 million barrels of $0 i 1$ per square mile. Additional data useful in evaluating the deposit, including generalized stratigraphy and mineralogy, detailed lithologic descriptions of the core, rock specific gravity, and core-hole logs, are presented with the oil-yield data. The sampled Wyoming oil shale resembles Mahogany-zone oil shale in rock properties and gross mineralogy. A statistically derived equation relating shale density to oil yield for the Wyoming deposit compares with a similar relationship valid for the better known Mahogany-zone oil shales in Colorado and Utah. A density log from Wyoming Corehole No. 1 is calibrated for direct oil-yield logging. The alternating rich and lean beds of shale at this site may permit creating the permeability necessary for direct production of shale oil from the shale in place.

Snyder, L. R., and B. E. Buel1. 1968. Nitrogen and oxygen compound types in petroleum. A general separation scheme. Ana1. Chem. 40: 1295-1302.

An intergrated scheme has been developed for the separation of the oxygen and nitrogen compound types present in high boiling petroleum fractions into reasonable clean cut fractions for further analysis by other techniques. Cation and anion exchange are used in conjunction with adsorption chromatography on alumina, silica, and charcoal. The resulting separations are experimentally convenient, repeatable, and predictable, and sample recoveries are satisfactory. Sample reactions during separation appear to be generally minor and do not interfere with sample 
analysis. The use of this separation scheme - in whole or in part - by different workers should also serve to interrelate their findings on the analysis of different crude $0 i 1$ fractions.

1967

Haines, W. E., G. L. Cook, and G. U. Dinneen. 1967. Techniques for separating and identifying nitrogen compounds in petroleum and shale oil. Reprint from the Proceedings of the 7th World Petroleum Congress. pp. 83-92.

An understanding of the nitrogen compounds in petroleum and shale oil is important to solving the problems created by these compounds. Individual nitrogen compounds were isolated from crude oil using liquid-solid and gas-1iquid chromatography and chemical treatment. These compounds were identified using spectral techniques. Nitrogen compounds in high-boiling shale oil fractions were characterized by mass spectral analyses of thermal diffusion fractions. A new method of determining nitrogen types was applied to fractions from crude $0 i 1$ and shale oil. The results suggest that the major differences are quantitative rather than qualitative.

Melton, N. M., and T. S. Cross. 1967. Fracturing $0 i 1$ shale with electricity. Colo. Sch. Mines Quart. 62(3): 45-62.

Laboratory studies to evaluate the use of electricity for fracturing various grades of Colorado oil shale were started in 1964. Breakdown voltage requirements ranged up to several thousand volts and varied widely from one grade of shale to another. With few exceptions, the shale samples were readily fractured at relatively low current levels.

On the basis of the encouraging results obtained in the laboratory, experiments were expanded to a small-scale field project in an abandoned oil shale mine tunnel near Green River, Wyo. The purpose of these experiments was to study electrical characteristics of oil shale when subjected to overburden pressure. In general, these tests confirmed the laboratory experiments. Fracturing was accomplished at all electrode spacings used. The spacings varied from 3 to 129 feet.

Based upon the results obtained in the mine-tunnel experiments, a test site 7-1/2 miles west of Rock Springs, Wyo., was selected for a larger scale field experiment. Fracturing tests were conducted in four shallow wells drilled in the oil-shale formation. Some new permeable zones were created but, in general, the induced permeability between wells was not up to desired levels. In an attempt to improve the induced permeability, two conventional nitroglycerin well bore shots were detonated in one of the wells. Air-injection tests made after the detonations showed appreciable improvement. 


\section{6}

Coffer, H. F., and E. R. Spiess. 1966. Commercial applications of nuclear explosives: the answer to oil shale? Colo. Sch. Mines Quart. 61(3):69-88.

Numerous contained nuclear explosions have been conducted in tuff, alluvium, dolomite, granite, and salt. These tests point up nuclear explosives as an economic method of breaking huge tonnages of rock underground. The remaining question is whether or not such broken up rock piles can be turned to commercial advantage.

Nuclear explosions are currently being planned for use in gas production, gas storage, copper leaching, and waste disposal. Each of these applications is discussed briefly, with emphasis on the economics. In the first two, the application is straight-forward: fire the nuclear explosive and use the resulting rock pile (chimney) for the well bore or storage tanks. In the leaching and waste disposal prospects, however, the engineering to utilize the rock pile will make or break the project. Discussion is included on the radiation problem, largely psychological in the case of contained explosions. Also described are the best areas in the oil shale for nuclear test programs and the limiting features such as thickness, depth, and richness of the oil shale.

The same analysis holds true for the use of nuclear explosives in recovery of oil from oil shale. There is little doubt that a nuclear explosive can build a large pile of broken up oil shale. The question is--can this oil shale pile be processed to yield economic oil? At present the answer has to be--we don't know. But the possible limitation is not the nuclear explosive, it is the in situ burn. With the advantage offered by in situ retorting (no rock handling, no waste disposal problems) and the size of the oil shale target applicable to nuclear explosives, engineering of the process of retorting nuclear-created rock piles is a must.

Included in the paper is a discussion of real or possible problems associated with nuclear explosive engineering. The only major problem is the seismic shock wave. This limits the size of explosive which can be used near important surface structures.

\section{5}

Anon. 1965. Colony describes a process for extracting shale oil. Min. Eng. $17(8): 62-63$.

The question of optimum size for plant facilities in full commercial production has been studied extensively by Colony. Using the typical room and pillar method, optimum mining and retorting rate appears to be about 60,000 to $80,000 \mathrm{tpd}$. The minimum rate for an economical operation would be about 50,000 tpd. Based on the average oil content of the shale, a plant processing 60,000 tpd is expected to produce 50,000 bbl per day. Current U.S. demand is around 10,000,000 bb1 per day. 
Cummins, J. J., and W. E. Robinson. 1964. "Normal and isoprenoid hydrocarbons isolated from oil-shale bitumen." J. Chem. Eng. Data 9: 304-307.

Normal and isoprenoid paraffins were identified in a bitumen obtained from Colorado oil shale. The identified $n$-paraffins represented 1.0 percent of the total bitumen and ranged from $\mathrm{C}_{13}$ to $\mathrm{C}_{33}$ compounds. Odd carbon numbered $n$-paraffins were present in greater quantity than even carbon numbered $n$-paraffins by a ratio of 3.6 to 1 in the range of $C_{25}$ to $\mathrm{C}_{33}$ compounds. Five isoprenoid compounds represented 3.4 percent of the total bitumens and were identified as 2,6,10, 14-tetramethylhexadecane, $2,6,10,14$-tetramethyl pentadecane, 2,6,10, trimethylpentadecane,

2,6,10-trimethyltridecane, and 2,6,10-trimethyldodecane. Identification of isoprenoid compounds in an oil-shale bitumen provides information for the presence of biological remains in oil shale and may serve as a means to the better understanding of the overall structure of kerogen.

East, J. H., Jr., and E. D. Gardner. 1964. 0i1-shale mining, Rifle, C0. 1944-1956. U. S. Bur. Mines Bu11. 611.

A report of oil shale mining experience and techniques gained at Rifle, Colorado for 1944-1956.

Smith, J. W., N. B. Young, and D. L. Lawlor. 1964. Direct determination of sulfur forms in Green River oil shale. Anal. Chem. 36(3): 618-622.

Pyrite, organic, and sulfate sulfur in Green River oil shale are determined directly by the method presented. Quantitative, interference-free chemical separations are performed consecutively on the same sample. Key to the determination is a new method for decomposition of pyrite by 1 ithium aluminum hydride reduction. For pyrite sulfur, the relative standard deviation of the determination is about $\pm 1.5 \%$ of the determined value, and for organic sulfur about $\pm 6 \%$. With this new method, forms of sulfur in Green River oil shale can be determined with precision and accuracy satisfactory for composition studies. The classical Power and Parr method produces erroneous results.

\section{2}

Jaffé, F. C. 1962. 0il shale. Part I: Nomenclature, uses, reserves, and production. Colo. Sch. Mines Miner. Ind. Bull. 5(2):11 pp.

A 1962 review covering the subjects: 1) Classification of oil shales; 2) Use of oil shales; 3) $0 i 1$ shale reserves; and 4) $0 i 1$ shale production. 
Dinneen, G. U., G. L. Cook, and H. B. Jensen. 1958. Estimation of types of nitrogen compounds in shale-oil gas oil. Anal. Chem. 30: 2026-2030.

A systematic procedure for the separation and characterization of the types of nitrogen compounds in shale-oil gas oil has been developed. First, a concentrate of the nitrogen compounds was prepared from a gas oil by adsorption. The concentrate was separated into fractions by molecular distillation and thermal diffusion. The types of compounds present were postulated by interpreting the similarities and differences shown in spectra on the series of fractions. Elemental and functional group analyses, and physical property determinations were used to aid in these interpretations. A quantitative estimate of the composition of the nitrogen-compound concentrate in terms of model compounds was also made.

\section{$\underline{1954}$}

Rube1, A. C. 1954. Liquid fuels from oil shale - A critical review. J. Petroleum Technology 6(2):9-16, 19-20.

Shale deposits of northwestern Colorado contain more than 100 billion barrels of recoverable shale oil from which, by processes now developed, high quality liquid fuels, gas, sulfur, ammonia, and petrochemical products may be produced.

Experience during the past two years indicates that in the immediate future we face an increasing dependence upon crude supplies outside of the United States.

Studies conducted by the National Petroleum Council indicate that a considerable proportion of this shale oil may be recovered and processed into products equal to those from natural crudes on the Pacific Coast at a cost closely approaching current prices from natural crude.

It would therefore seem to be in the public interest for the petroleum industry and the Defense Department to thoroughly explore the possibilities of developing this great resource as a supplement to our domestic crude supply.

Immediate industry study on an expanded pilot plant scale is suggested.

\section{2}

Dinneen, G. U., J. R. Smith, and C. W. Bailey. 1952. Product composition. Ind. and Eng. Chem. 44(11): 2647-2650. 
The compositions of shale $0 i 1 \mathrm{~s}$ produced at $1200^{\circ}, 1500^{\circ}$, and $1700^{\circ} \mathrm{F}$, were investigated by systematic analyses. The material in the oils boiling below $280^{\circ} \mathrm{C}$, was separated into narrow-boiling fractions by distillation. The composition of each fraction was determined from a consideration of data obtained from one or more of the following determinations: silica gel adsorption analysis; infrared, ultraviolet, or mass spectrum; refractive index; density; and boiling range.

Al1 three of the oils studied in this investigation are much more aromatic than oils ordinarily produced by the usual retorting methods. The $1500^{\circ}$ and $1700^{\circ} \mathrm{F}$ 0ils consist essentially of aromatic hydrocarbons and sulfur and ritrogen compounds. The contents of benzene and naphthalene increase with retorting temperature. The contents of toluene and the methylnaphthalenes reach a maximum in the $1500^{\circ} \mathrm{F}$ 0i1. Phenol, 0-cresol, and $\mathrm{m}$-cresol are the predominate compounds in the tar acids from the $1500^{\circ} \mathrm{F} 0 i 1$. The tar bases from this oil show large relative quantities, of 2,4,6-trimethylpyridine and 2,4-dimethylpyridine.

Mapstone, G. E., and B. Nartsissov. 1952. Sulphur in oil shale or torbanite. J. App 1. Chem. (London) 2: 405-408.

Mott's rapid method for the determination of sulphate and pyritic sulphur in coal can be applied to oil shale or torbanite, the pyrites content being calculated from the iron extracted. The organic sulphur is best calculated by subtracting the pyritic sulphur from the total sulphur content of the hydrochloric acid-extracted material as determined by the quartz-tube method.

On the pyrolysis of the torbanite approximately only $1 \%$ of added pyritic sulphur appears as organic sulphur in the oil. Similarly the addition of calcium carbonate had no effect and calcium hydroxide had only a slight effect on the organic sulphur content of the $0 i 1$. None of these materials affected the oil yield significantly.

Kinney, I. W., Jr., J. R. Smith, and J. S. Ball. 1952. Thiophenes in shaleoil naphtha. Anal. Chem. 24(11): 1749-1754.

Almost $80 \%$ of the sulfur in shale-0il naphtha occurs in thiophenic compounds. Isolation and identification of individual members of this group of compounds provide fundamental data for solving processing problems caused by them. A method was developed for the isolation and identification of thiophenes. Seventeen thiophenes were identified from a naphtha distilled from Colorado shale oil. Quantitative estimates were made of the contents of most of these. The seventeen thiophenes represent about two thirds of the thiophenic sulfur in the naphtha. Isolation of the thiophenes was accomplished by fractional distillation, adsorption, and derivative formation. The identification was based on a combination of mass spectral, mercuric acetate derivative, methylation, and hydrogenation data. The quantitative identification of this large group of 
thiophenes from a single source permits establishing a pattern of their occurrence. From these data, mechanisms for the formation of thiophenes may be postulated.

\section{$\underline{1950}$}

Dancy, T. E., and V. Giedroyc. 1950. Further researches on the determination of the chemical composition of oil shales. J. Inst. Petrol. 36: 593-603.

The removal of mineral matter from the Ermelo Torbanite (South Africa), St. Hilaire oil shale (France), and Kimmeridge oil shale (Dorset) was studied using a chemical and a physical method. The former, using mineral acids, caused some attack of the kerogen, and this effect was studied in some detail. The physical method, employing a grinding process with oil, was unsuitable for the Kimmeridge, but was used for the indirect determination of the composition of the kerogen of the other samples. These compositions were compared with those calculated from the chemically enriched shales.

Hubbard, A. B., and W. E. Robinson. 1950. A thermal decomposition study of Colorado oil shale. U.S. Bur. Mines RI 4744.

The thermal degradation of oil shale kerogen as a function of temperature is studied.

Mapstone, G. E. 1950. Nitrogen in oil shale and shale oil. XIII. An approximate method for determining pyridine nitrogen in oil shale and similar materials. J. Proc. Roy. Soc. N. S. W. 84: 34-37.

Approximately five-sixths of the pyridine ring nitrogen in a sample are oxidized after an after-boil of one hour under standard conditions of the Kjeldahl method, the complete digestion requiring between one and a half and two hours. No other type of nitrogen compound examined interfered, so, in addition to being a qualitative method for detecting pyridine rings in an unknown substance, it can be used as the basis for a very approximate quantitative method. Similar results can be obtained by eliminating the sodium sulphate from the digestion mixture, but some other compounds interfere.

\section{8}

Ferris, B. J. 1948. Studies of soluble material in oil shales. Mines Mag. $38(9): \quad 19-22,28-44$.

Conclusions reached as a result of the investigations described in this paper may be summarized as follows: 
1. The soluble matter in Green River oil shale is apparently uniformly dispersed throughout the shale.

2. The greater solubility of the organic matter in oil shale particles of small size is primarily a result of the larger surface area exposed to the leaching action of the solvent.

3. The relationship which exists between the soluble extract and the oil yield of Green River oil shales may expedite oil shale assays in the field.

4. The soiubility of the "kerogen" in Green River oil shale is:

a. an inverse function of particle size

b. a direct function of time of exposure to the solvent

c. a direct function of the temperature of the solvent

d. an inverse function of specific gravity

e. a direct function of oil yield.

Other studies have shown that the soluble extract obtained from oil shales is also a function of the chemical composition of the organic matter in the shale, and of the chemical composition of the solvent.

Mapstone, G. E. 1948a. Nitrogen in oil shale and shale oil. I. The nitrogen compounds present in kerogen. J. Proc. Roy. Soc. N. S. W. 82: 79-84.

The nitrogen content of shale kerogens is far from insignificant and appears to be of porphyrinic (chlorophyll) and protein origin. Treibs has identified small amounts of several porphyrins in $0 i 1$ shales but in quantities too small to account for more than a fraction of the total nitrogen present. It is suggested that the bulk of the nitrogen of the shale kerogen is of protein origin and has been extensively modified during the kerogen formation.

Mapstone, G. E. 1948b. Nitrogen in oil shale and shale oil. II. Organic nitrogen compounds in shate oil. J. Proc. Roy. Soc. N. S. W. 82: 85-90.

The only organic nitrogen compounds that have been isolated and identified in shale oil are pyridine and its simple methyl and ethyl derivatives. The only bicyclic base isolated in pyrindane in which the pyridine ring is fused to a cyclopentane ring. Quinoline and isoquinoline derivatives have been claimed but have not been identified with certainty. 
Mapstone, G. E. 1948c. Nitrogen in oil shale and shale oil. III. Nitrogenous products from the pyrolysis of porphyrins and proteins. J. Proc. Roy. Soc. N. S. W. 82: 91-95.

On the basis of the evidence presented in this review it appears that the nitrogen compounds that may be present in shale oil are extremely varied. Thus pyrrole homologues and possibly porphyrins and their intermediate decomposition products can be expected from the porphyrins present in the kerogen. Proteins and modified proteins could give rise to pyrrole and pyrrole derivatives such as indole and pyrocoll, as well as to pyridine type bases including quinoline and isoquinoline, and to diazines, amides and nitriles. Ammonia liberated from protein material, etc., is very reactive at the high temperature involved in the retorting process, so secondary reactions involving the formation of heterocyclic nitrogen compounds must not be overlooked. Also, secondary reactions involving the modification and decomposition of the nitrogen compounds formed during the initial pyrolysis of the kerogen no doubt have a very important bearing on the nature and distribution of the nitrogen compounds present in the resultant crude 011 . These reactions will be dealt with in a subsequent paper.

Mapstone, G. E. 1948d. Nitrogen in oil shale and shale oil. IV. Pyrolytic reactions involving the formation and decomposition of tar bases. J. Proc. Roy. Soc. N. S. W. 82: 96-106.

From this review of the secondary pyrolytic reactions that could take place during the retorting of $0 i 1$ shale it is apparent that a wide range of cyclic nitrogen compounds may be present in shale oil. These include pyrrole and pyridine, their homologues and benz-derivatives, together with materials which contain more than one heterocyclic ring. Diheterocyclic compounds also may be formed though, for stability, the two hetero atoms should not be adjacent. It is also possible that non-cyclic, non-basic nitrogeneous compounds such as nitriles and thiocyanates may be present.

Decomposition of the bases formed may influence the products appreciably, thus pyrroles can give rise to indoles and ammonia while pyridines would tend to give mainly dipyridyls with a small amount of nuclear decomposition to give hydrocarbons and hydrogen cyanide.

Mapstone, G. E. 1948e. Nitrogen in oil shale and shale oil. V. The determination of nitrogen in shale oil and oil shale. J. Proc. Roy. Soc. N. S.W. 82: $129-134$.

The conditions have been determined for the accurate determination of the nitrogen content of shale oil and oil shale by the Kjeldahl method. A minimum digestion time of one and a half hours from the time the digestion mixture clears is necessary for the correct result to be obtained in both cases. This appears to be due to the presence of compounds containing pyridine nuclei. 
Mapstone, G. E. 1948f. Nitrogen in oil shale and shale oil. VI. Acid washing of crude shale oil. J. Proc. Roy. Soc. N. S. W. 82: 135-144.

The nitrogen compounds in crude shale oil have been shown to fall into the three classes:

(1) Tar bases, which may be extracted by dilute acid.

(2) Dilute-acid-insoluble but acid-polymerizable compounds.

(3) Compounds stable towards and not extractable by concentrated sulphuric acid.

Twenty-five percent acetic acid will extract the tar bases without significantly affecting the second class, while dilute (normal) mineral acids cause some polymerization of the second class at the same time.

The total nitrogen content of the crude shale oil increases with the boiling point. The tar bases increase to a maximum (\% N.) in the $500-$ $600^{\circ} \mathrm{F}$ fraction and then decrease again but, even with the gasoline fraction, they contain but part of the total nitrogen present in the fraction.

On thermal cracking the fraction of the nitrogen in various cuts appearing as tar bases increases. A large proportion of the nitrogen in the oil remains in the residuum and coke. The nitrogen content of shale oils from several different sources has been examined.

Mapstone, G. E. 1948g. Nitrogen in oil shale and shale oil. VII. Distribution of kerogen nitrogen on carbonization. J. Proc. Roy. Soc. N. S. W. 82: 145-149.

Samples of shale from different parts of the Glen Davis seam have been examined and the distribution of the nitrogen on carbonization determined. Over half the nitrogen originally present in the shale remains in the carbonization residue.

\section{4}

Berenblum, I., and R. Schoental. 1944. The difference in carcinogenicity between shale oil and shale. Brit. J. Exp. Pathol. 25: 95-96.

A sample of blue shale oil was found to be strongly carcinogenic to the mouse's skin, whereas a concentrated extract of shale (the natural product from which shale $0 i 1$ is obtained by retorting) failed to produce any tumours after 40 weeks of painting. 
These results confirm the view, previously expressed by the authors (1943), on the evidence of fluorescene analys is of chromatographic fraction of shale $0 i 1$ and extract of shale, that the carcinogenic constituents of shale oil do not exist in the original shale, but owe their presence to pyrolytic effects during the retorting.

\section{8}

B1ade, 0. C. 1938. Ichthyol - Its source and properties. U.S. Bur. Mines Info. Circ. 7042. 28 pp.

The term "Ichthyol" is a name applied loosely to certain preparations used in pharmacy. These preparations do not occur as such in nature but are manufactured by various chemical processes. Ichthyol is the name trademarked for a product manufactured by the Ichthyol-Gese11schaft (Cordes, Hermanni \& Co.) of Hamburg, Germany, and marketed in this country by Merch \& Co., Inc. Although used in the literature rather loosely, the correctly applied word refers to the product obtained by sulphonating and then neutralizing with ammonia a distillate from the oil retorted from a certain high-sulphur bituminous shale found near the village of Seefeld in the Austrian Tyrol. Due to the fact that fossils of fish and marine animals occur in the limestone associated with the bituminous shale, these deposits have long been known as the "ichthyolite schists of Seefeld". The Greek word "ichthys" for fish and Latin word "oleum" for $0 i 1$ are the words from which the term is derived. 
ANNOTATED BIBLIOGRAPHY

SECTION II

OIL SHALE TECHNOLOGY 
ANNOTATED BIBLIOGRAPHY

SECTION II: OIL SHALE TECHNOLOGY

1976

Anon. 1976. Petrosix: a Brazillian answer to oil shale technology. Eng. Min. J. 176(1): 158-162.

Research and development efforts focusing on oil shale prototype mine and processing plant of Brazil's Petrosix are reviewed. Petrosix, a unit of Brazil's state-controlled oil company Petrobras, staged a series of production runs in the prototype plant starting in 1972. These individual processing campaigns were shaped to determine design criteria engineering parameters, operating conditions, and capital and operating costs for a venture based on the Irati shales of Parana State. The prototype mine and plant has shown a consistent yield of 1,000 bbl of $011,36,500 \mathrm{cu} m$ of light gas (900 Btu per $\left.\mathrm{m}^{3}\right)$, $17 \mathrm{mt}$ of sulphur, and a theoretical $75 \mathrm{bbl}$ of $L P G$ from every $2,000 \mathrm{mt}$ of shale.

Novak, A. 1976. 0 il Shale - 1976/1977. Shale Country 2(6): 2-6.

The oil shale industry took some bumps in 1976, but hangs tight for 1977.

Riley, R. G. 1976. Separation of polar shale oil compounds using high-speed 1 iquid chromatography. BNWL-2128. Battelle-Northwest, Richland, Washington.

Stanford Research Institute Staff. 1976. 0il shale bibliography, First Edition. Report to U.S. Environmental Protection Agency office of Energy, Minerals and Industry. $219 \mathrm{pp}$.

Part I consist of indexes to the documents which are listed in Part II. Computer printouts were provided for Part II by TRW (Redondo Beach, CA). The documents listed in Part III were provided by NIOSH's Clearinghouse for Occupational Safety and Health Information (Cincinnati, $\mathrm{OH}$ ).

The documents in Part II are listed in order of the control number assigned by the TRW library system. These numbers serve only to conveniently reference the documents to the Keyword Listing and to the Author and Organization Indexes given in Part I. These documents may be obtained by contacting the "ORGANIZATION". The listing includes publications dating from 1913 to 1976.

Documents in Part III (contributed by NIOSH) are listed by subject (e.g., Cancer, Skin Cancer and within subjects, alphabetically by author. These publications may be ordered by supplying the Control 
Number (e.g., NIOSH-000...) to: Publications, Division of Technical Services, National Institute for Occupational Safety and Health, 4676 Columbia Parkway, Cincinnati, $\mathrm{OH}$ 45226. The listing includes keywords and an abstract for each document and contains publications dating from 1910 to 1975 which are pertinent to health effects related to the shale oil industry. (Publication dates are given in the following form:

Year/Month/Day. "Reference 1" indicates the periodical in which the publication has appeared.)

Part IV consists of additional references provided for this effort by literature searches conducted by Stanford Research Institute. The publications date from 1973 to 1976 and are listed alphabetically by title.

Yen, T. F. (ed.). 1976. Shale oil, Tar Sands, and Related Fuel Sources. Advances in Chemistry Series. pp. 151-184. Amer. Chem. Soc., Washington D. C. Papers:

1. Poulson, R. E., C. M. Frost, and H. B. Jensen. Characteristics of Synthetic Crude from Crude Shale 0 il Produced by in Situ Combustion Retorting.

2. Clugston, D. M., A. E. George, D. P. Montgomery, G. T. Smiley, and H. Sawatzky. Sulfur Compounds in 0ils from the Wester Canada Tar Belt.

3. Ruberto, R. G., D. M. Jewe11, R. K. Jensen and D. C. Cronauer. Characterization of Synthetic Liquid Fuels.

4. Moussavi, M., D. K. Young, and T. F. Yen. Rate of Dissolution of Carbonate Mineral Matrix in $0 i 1$ Shale by Dilute Acids.

5. Weil, S. A., H. L. Feldkirchner, and P. B. Tarman. Hydrogasification of 0 il Shale.

6. Frost, C. M., R. E. Poulson and H. B. Jensen. Production of Synthetic Crude from Crude Shale $0 i 1$ Produced by in Situ Combustion Retorting.

7. Meyer, W. C. and T. F. Yen. Solution of Silica in Green River 0il Shale.

8. Miller, J. S. and R. T. Johansen. Fracturing 0il Shale with Explosives for in Situ Recovery.

9. Redford, D. A. and P. F. Cotsworth. Development of Communication Paths within a Tar Sand Ben.

10. Bunger, J. W. Characterization of a Utah Tar Sand Bitumen.

11. Davis, A. J., III, and T. F. Yen. Feasibility Studies of a Biochemical Desulfurization Method. 
12. Moschopedis, S. E. and J. G. Speight. Chemical Modification of Bitumen Heavy Ends and Their Non-Fuel.

13. Zielke, C. W., W. A. Rosenhoover and E. Gorin. Direct Zinc Chloride Hydrocracking of Sub-bituminous Coal and Regeneration of Spent Melt.

14. Marschner, R. F and J. C. Winters. Differences Among Ozokerites.

\section{$\underline{1975}$}

Anon. 1975. Laramie Energy Research Center. U.S. Dept. of Interior, Bureau of Mines.

Highlights of the origins, work now in progress 1975, value of present work and the facilities available at the Laramie Energy Research Center.

Arnold, C., Jr., 1975. Effect of heating rate on the pyrolysis of 011 shale. Am. Chem. Soc., Div. Pet. Chem. Preprint 20(n): 228-234.

The effect of increasing the heating rate from $4^{\circ} \mathrm{C} / \mathrm{min}$ to $40^{\circ} \mathrm{C} / \mathrm{min}$ on the pyrolysis of oil shale was to decrease the yield of $0 i 1$ and gaseous organic products by $23 \%$. The higher heating rates also tended to favor the formation of higher boiling components in the shale oil obtained. Under the conditions which prevailed in these small scale runs, namely small particle size and flowing streams of helium, it is postulated that metastable residues were formed which underwent complete volatilization (at slow heating rates). The extent to which these metastable residues were formed was a function of the heating rate. Maximal amounts of the residue were favored by the intermediate heating rate of $20^{\circ} \mathrm{C} / \mathrm{min}$. The activation energies for all three shales studied increased by a factor of 2.0 to 2.5 over the entire temperature and conversion range. High reaction orders were observed in the early stages of the decomposition when kerogen was breaking down at the same time that bitumen and oil plus gas were being formed. The reaction order decreased with conversion to a value somewhat greater than unity then remained constant during the second half of the pyrolysis. 13 refs. (NTIS)

Anon. 1975. Paraho plans commercial sized oil shale mine and vertical retort. World Mining 28: 42-45.

The 30 barrel per ton shale from the highest grade "Mahogany Bed" will be mined at the former U.S. Bureau of Mines demonstration mine at the rate of 12,500 tons per day to produce 11,500 tons of plus half inch mines-3 and one half inch retort feed. One of the problems of the Paraho process is that the retort cannot handle fine shale. The shale will be charged into a 42-foot outside diameter 104-foot high retort. 
Maximum yield should be 7300 barrels of shale $0 i 1$ and $8,000,000$ BTUs of product gas per day. Direct-heated Paraho retorts using air were used in the economic analysis. For this operation, liquid oil recovery of 95 percent of modified Fisher assay liquid yield was used. The low BTU gas produced from the retort $(118,000,000,000$ BTU per day) will be exported, presumably to a new electric power generating plant constructed by a public utility nearby. (NTIS)

Barker, L. K. 1975. Producing SNG by hydrogasifying in situ crude shale oil. PB-240 841. (NTIS)

The purposes of this research were to determine the effect of temperature and pressure on the yield and composition of gas which could be obtained from an in situ crude shale oil and to determine what effect extended operating times would have on gasification. Tests were also made to determine the temperature at which 90 volume-percent of the ethane was converted to methane and whether or not a cobalt-molybdate-on-alumina catalyst plays a significant part in conversion of light hydrocarbons. Both in situ crude shale oil and liquefied petroleum gas were used as feedstocks. Temperatures of 800 degrees to 1,400 degrees $F$, pressures of $500,1,000$, and $1,500 \mathrm{psig}$, and operating times of 19 to 67 hours were used. A cobalt-molybdate-on-alumina catalyst was used for the catalyst experiments. (NTIS)

Braun, R. L., and A. J. Rothman. 1975. 0il-shale pyrolysis: kinetics and mechanism of oil production. Fuel 54(2): 129-131.

Literature data on the thermal decomposition of the organic material in Colorado oil shale are analyzed. Inclusion of a thermal induction period in the data analysis results in a concise interpretation of the kinetics of oil production in terms of a simple mechanism involving two consecutive first-order reactions. The rate constants and activation energies for these two reactions are deduced. 7 refs. (NTIS)

Bureau of Land Management Staff. 1975. Department of Interior Draft Environmental Impact Statement: Proposed development of oil shale resources by the Colony Development Operation in Colorado Dept. of Interior Pub1. DES-75-62.

The proposed Federal action is the consideration of a right-of-way permit for an oil shale products pipeline from a plant site in Colorado to Lisbon Valley, Utah. Directly related to this Federal action is the development of a 4,000 acre underground $0 i 1$ shale mine; mining of 61,000 tons per day of $0 i 1$ shale for 20 years; construction and operation of a 47,000 barrel a day oil shale plant; construction of two dams - Davis Gulch processed oil shale disposal catchment and Middle Fork flood control; disposal of processed oil shale on 800 acres; construction of a 194-mile, 16-inch shale oil pipeline from the plant site on Roan Plateau to Lisbon Valley, Utah; 
development of a 15-mile-long service corridor in the Parachute Creek valley; construction of a 75-acre terminal site in Grand Valley; construction of two $230 \mathrm{kV}$ powerlines to the plant site; a 337-acre exchange of land between BLM and Colony Development Corporation; and diversion of 12.5 cubic feet per second of water from the Colorado River.

Clark, C. E., and D. C. Varisco. 1975. Net energy and oil shale. Colo. Sch. Mines Quart. 70(3): 3-20.

Concept definition is followed by application to subject and appropriate clarifications to calculate the net yield of the industry. Energy flows, external input, boundaries, and thermal efficiency are dealt with and illustrated in tabular and graphical form and supplemented by calculations in Appendix. 4 refs. (NTIS)

Coalgate, J.L. 1975. A study of coal-associated waste resulting from the mining, processing, and utilization of coal. FE-1218-T-1. (NTIS)

This bibliography was prepared to provide an extensive, readily available source of information dealing with the utilization of wastes produced during the mining, preparation, combustion, gasification and coking of coal. The attendant wastes could potentially serve as sources of fuels, building and construction materials, and as sources of new materials for the metallurgical, chemical water treatment and agricultural industries. The bibliography covers work produced in the period from 1900 to the present. (NTIS)

Cottingham, P. L., and L. G. Nickerson. 1975. Diesel and burner fuels from hydrocracking in situ shale oil. Am. Chem. Soc., Div. Pet. Chem. Preprint 20(2): $535-540$.

Investigation of the quantity and quality of diesel fuels and fuel oils that could be prepared from the liquid product obtained by oils hydrocracking of in situ combustion shale oil. A sample of the in situ crude oil was hydrocracked at operating conditions that had been found by previous experiments to be effective in eliminating most of the nitrogen and sulfur from the $0 i 1$ and in greatly reducing the average boiling point of the oil. The hydrocracked oil was distilled into a $350 \mathrm{~F}$ end-point reforming stock and small-volume heavier fractions. Diesel fuels, suitable for use also as fuel oils, were prepared by blending of small-volume fractions. The yield of diesel fuels was 51-64 vol\% of the in situ crude, and the yield of No. 4 fuel oil was 21.64 vol\%, for a total of 73.15 vol\% of the in situ crude that could be used as low-sulphur diesel fuels or Nos. 1 through 4 burner fuels. 9 refs. (NTIS) 
Decora, A. W. 1975. The outlook and status of in situ oil shale research. Paper Am. Nuc. Soc. November 17-21, San Francisco, CA.

In situ, or underground, processing of oil shale offers many potential advantages over mining and surface processing. In addition to possible economic and environmental advantages it also offers the possibility of application to low-grade oil shales. Research on in situ methods has been conducted by industrial and government groups, but the technology has not been completely developed. This research is continuing and should be accelerated by individual groups and by cooperative efforts to speed development of an oil shale industry.

Doggett, J.N. 1975. Summary of large block $0 i 1$ shale retorting experiments. Rep UCID-16699, 15 pp. (NTIS)

An unexplained rapid heating of large blocks of oil shale in a 150-ton experimental retort and reported by the Bureau of Mines was investigated. It was found that this effect is present in blocks as small as 170 1b when retorted in air but not when retorted in nitrogen. There is a basic difference in character of the internal temperature-time plots between those blocks run in air and those run in nitrogen. The indication is that the presence of oxygen (or some other nonnitrogen constituent of air) greatly increases the rate of heating deep in the rock. Secondly, the fact that the internal temperature goes above the surface temperature indicates that this effect is exothermic and not some mechanism that increases the effective thermal conductivity.

Eliason, M. D. 1975. 0 il shale-if not now, when? Shale Country 1(10): 2 . Arguments for oil shale development.

Fausett, D. W. 1975. A mathematical model of an oil shale retort. Colo. Sch. Mines Quart. 70:(3): 273-313.

Model of the kinetics of $0 i 1$ shale pyrolysis and a model of the retorting combustion process is offered. A system of thermal decompositions is presented that provides a description of the mechanism of oil shale pyrolysis. Specific rate constants for that system have been determined by a least squares procedure, and are shown to exhibit a temperature dependence that is in good agreement with the Arrhenius equation. Analytical expressions for temperature distribution and oxygen concentration in the retort are presented. A numerical method for solving those equations is presented. A procedure is given for combining the kinetics model and the temperature profile model to produce a mathematical model of the oil shale retort. An example of a simulated retort run is discussed using values for the parameters in the model that are based on physical data from an experimental retort run. Equation, graphs, and diagrams show simulation. 64 refs. (NTIS) 
Hanson, R. L., and N. E. Vanderborgh. 1975. Characterization of oil shale by laser pyrolysis - gas chromatography. Anal. Chem. 47(2): 335-338.

Laser pyrolysis gas chromatography permits a rapid and sensible method for the characterization of shales. The total analysis time is but ten minutes. Moreover, the method permits easy automation and shows good promise as a routine analytical procedure.

The laser program also gives data for $\mathrm{CO}$ and $\mathrm{CO}_{2}$. This information should lead to a characterization of the carbonate content of the shale and also the extent of oxidation of the organic material.

Herrell, A. Y., and C. Arnold, Jr. 1975. Preliminary studies on the recovery of $0 i 1$ from Chattanooga shale. SAND-75-0344. (NTIS)

Three exploratory investigations have been performed to examine the recovery of oil from the Chattanooga black shale formation. Thermogravimetric data were analyzed to yield an average activation energy of $57.1 \mathrm{kcal} / \mathrm{mole}$ for the conversion process; positive deviations from a reaction order of 3.7 were observed suggesting the presence of autocatalytic effects at low conversion levels. Thermal chromatographic analysis indicated that the maximum organic product release occurred at approximately $435^{\circ} \mathrm{C}$ and resulted in an oil of relatively low distillation range. A packed bed of shale was retorted in the self-sustained combustion mode thus suggesting the feasibility of this mode for in situ oil recovery. Comparisons with oil shale from Colorado's Green River Formation have been made throughout.

Jackson, L. P., and A. W. Decora. 1975a. Kerogen constituents: reduced chlorophyllin as a model for the precursors of nitrogenous compounds in shale 0i1. Am. Chem. Soc., Div. Fuel Chem. Preprint 20(2): 147-53.

The reduction and pyrolysis of a commercially available plant pigment extract, chlorophyllin, is described. The amounts of bases formed and their boiling-range distribution are related to the hydrogen content of the starting materials. Mass spectral studies are given which show that many of the same types of bases are found in the pyrolysate and in an in situ light distillate. These results indicate that reduced chlorophyllin may be used as a model for the nitrogen-containing constituents in kerogen.

Jackson, L. P., and A. W. Decora. 1975b. Thermal reactions of shale-0il components: plant pigments as probable precursors of nitrogenous compound in shale oil. U.S. Bur. Mines RI 8018.

Reduced chlorophyllins were prepared and pyrolyzed in an effort to identify the role of plant pigments and their decomposition products in the nitrogenous compounds found in the product of oil-shale pyrolysis. The 
properties of the chlorophyllin pyrolysates were related to the composition of the reduced chlorophyllins with particular emphasis on the amount and types of nitrogen compounds formed. A comparison based on the types of nitrogen compounds present was made between shale oil and the chlorophyllin pyrolsates. This information was used to evaluate reduced chlorophyllin as a model of oil-shale kerogen insofar as the production of nitrogen compounds was concerned. The results indicate that the reduced chiorophyllin does represent a good model of shale-0il kerogen. (NTIS)

Johnson, W. F., D. K. Walton, H. H. Keller, and E. J. Couch. 1975. In situ retorting of oil shale rubble: A model of heat transfer and product formation in oil shale particles. Colo. Sch. Mines Quart. 70(3): 237-272.

A mathematical model of the pyrolysis of an $0 i 1$ shale particle, represented as an equivalent sphere, has been developed. The quantities of oil, gas, and carbonaceous residue formed from the kerogen initially present in the shale can be determined as a function of time for any specified heating cycle. Thermal decomposition of kerogen is represented by a kinetic scheme of 10 endothermic irreversible first-order reactions whose temperature dependencies are formulated as Arrhenius equations. The calculated fraction of kerogen converted to shale oil is determined by this kinetic scheme, and the development of the scheme is presented in some detail. Inorganic carbonate decomposition and water loss are included, since these endothermic reactions significantly alter the temperature profile in the particle and indirectly influence the quantity of oil formed. The thermal conductivity, heat capacity, and density at a given radius in the particle are determined by the temperature and degree of kerogen conversion at this radius as well as the initial organic content of the shale. The density is also a function of the water-loss, carbonate decomposition, thermal expansion, and swelling of the particle. Extension of the model to include organic burn-off can be readily accomplished by the addition of appropriate equations for combustion reactions and oxygen diffusion. Data are presented in graphical and tabular form. 39 refs. (NTIS)

Keighin, C. W. 1975. Resource appraisal of oil shale in the Green River Formation. Piceance Creek Basin, Colorado. Colo. Sch. Mines Quart. $70(3): 57-68$.

It is estimated that, in beds greater than 10 feet thick and yielding 25 gallons or more of oil per ton, there are 471 billion barrels (68 billion tonnes) of oil in place; of this total, 135 billion barrels (20 billion tonnes) are contained in the Mahogany Zone of the Parachute Creek Member. Included in these estimates are resources calculated for oil shale yielding 30,35 , and 40 gallons or more of oil per ton. If technology and economics permit use of lower grade resources, the total oil in place is significantly higher. Maps, tables, and curves illustrate evaluation. 16 refs. (NTIS) 
Klass, D. L. 1975. Sythetic crude oil from shale and coal. Chemtech. August 1975: 499-510.

The growing shortage and increasing price of crude oil and our national goal to become self-sufficient in energy behoove us to develop and commercialize alternative feeds for our refineries. Liquid produced from coal and/or oil shale are one of the more attractive alternates available because in terms of energy content, U.S. oil shale and coal represents its largest indigenous source of fossil fuel (Table 1) (1). This paper summarizes the various liquefaction processes under development and the major problems that must be faced in the manufacture of syncrudes from these naturai resources. Unfortunately little can be said here about economics because costs are not only sensitive to rapidly changing costs of money (liquefaction processes are capital intensive) and of solid feedstock, but also because economics are sensitive to scale, to markets for co-products, and to transportation costs.

Kunchal, K. S. 1975. Energy requirements in an oil shale industry: Inputoutput relationships based on Paraho's direct combustion retorting process. Colo. Sch. Mines Quart. 70(3): 21-29.

Systematic analysis of processes complemented by quantity calculations is presented. Comparisons with other fossil fuels are tabulated, and energy requirements shown diagrammatically. (NTIS)

Leach, H. J. 1975. Analys is of methods for underground mining of oil shale. Mining Congr. J. 61(5): 33-34

The objective of these remarks is to analyze underground mining systems for producing oil shale. A brief explanation of the geologic setting of the oil shale ore bodies assists this analysis. The oil shales under consideration are better described as marlstone and contain not oil but kerogen, a solid hydrocarbon which when heated converts to oil and gas. The formation covers 16,000 square miles in Colorado, Utah and Wyoming varying in thickness from a few hundred to $2000 \mathrm{ft}$. in the center of Colorado's Piceance Basin. Within the upper portion of the shale bed in Colorado and Utah is a relatively uniform, rich section called the mahogany zone. This zone, about $100 \mathrm{ft}$. thick, is overlain by an average of $1000 \mathrm{ft}$. of lean shale and sandstone, and contains an estimated recoverable 77 billion bbl. of oil in sections at least $30 \mathrm{ft}$. thick containing $30 \mathrm{gal}$. or more of oil per ton. This is the high grade shale of primary interest and since, at a predicted maximum production rate of 2 million bbl. per day, it constitutes about 100 years reserve, only this zone is considered in this discussion. (NTIS) 
Miller, P. G. 1975. Colorado pay dirt: Will oil shale compete with crude? Chilton's $0 i 1$ Gas Energy 1(1): 46-49.

After a review of the oil shale developments in the western US, as well as economic and ecological problems that must be resolved to turn shale into oil the author discusses three concepts of oil (kerogen) removal from shale (marlstone): (1) the direct system which exposes shale directly to a source of heat, (2) the indirect process which heats shale through a medium, and (3) the in situ method of oil extraction which minimizes environmental hazards. The cost of oil shale production and the rate of return are discussed in terms of their competitiveness with crude oil. (NTIS)

Oklahoma Univ. Staff. 1975. Energy Alternatives. PB-246-365. (NTIS)

This report develops a methodology for systematically identifying, assessing, and comparing energy alternatives in environmental impact statements (EIS). The report provides descriptions and data on the major energy resource systems in the United States and suggests procedures for using these descriptions and data. The study consists of two major parts. Part I contains descriptions of the coal, oil shale, crude oil, natural gas, tar sands, nuclear fission, nuclear fusion, geothermal energy, hydroelectric power, organic wastes, and solar energy resource systems plus descriptions of electric power generation and energy consumption. Each resource system description contains data and information on energy efficiencies, environmental residuals and economic costs. Part II describes procedures for using the descriptions and data contained in Part I in systematically evaluating and comparing the residuals, efficiencies, and economic costs of a proposed energy action and its alternatives, and suggests procedures for impact analyses. (NTIS)

Perrini, E. M. 1975. 0il from shale and tar sands. Chem. Technol. Rev. 51 Noyes Data Corp., Park Ridge, NJ, 307 pp.

The detailed, descriptive information in this book is based on U. S. patents issued since 1960 that deal with obtaining oil from shale and tar sands. The book describes over 215 processes related to the retorting and refining of oil shale and the separation of oil from tar sands. Many of these processes are in the pilot plant stage and will form the basis for large scale commercialization during the next decade. Another purpose served by the book: it can be used as a guide to the U. S. patent literature in this field. Five main sections of the book deal with oil shale retorting, oil shale refining processes, tar sands separation processes, tar sands retorting and refining processes, and recovery of metal values. (NTIS) 
Radian Corp. Staff. 1975. A western regional energy development study: primary environmental impacts. PB-246-264. (NTIS)

Arizona, Colorado, Montana, New Mexico, North Dakota, Utah, and Wyoming contain coal, oil, natural gas, oil shale, tight gas sands, tar sands, uranium, and geothermal resources. The report examines the primary environmental impacts of 38 energy resource development scenarios: the air and water emissions, solid waste, and land requirements of a plant or process. Projected ground level ambient concentrations of pollutants are compared with federal and state standards. Scènarios include all aspects of development: extraction, conversion, and transportation to the point of end use. (NTIS)

Ridley, R. D. and R. T. Crew, III. 1975. In situ oil shale process development. Colo. Sch. Mines Quart. 70(3): 123-127.

The Garrett process is described and plant is shown on plates. Operation, analyses, tests, and communications are discussed. (NTIS)

Rothman, A. J. 1975. Research and development on rubble in-situ extraction of oil shale (RISE) at Lawrence Livermore Laboratory. Colo. Sch. Mines Quart. 70(3): 159-178.

The process consists in forming a rubble chimney by the use of mining and high explosives and retorting in place using combustion in an air stream. A proposed method of mining and rubble formation is described, and technical questions in the process are outlined. Field work is planned, but not yet funded. An experimental program is underway to answer these questions, and is presented. Recent experimental and calculational results related to retorting and rubblization are given. Data are presented in tabular and graphical form. 32 refs. (NTIS)

Rutledge, P. A. 1975. Federal prototype oil shale program. Colo. Mining Assn./Denver Mining Yearbook 1975: 61-64.

At this point, the obvious question, one might ask, is all of this environmental assessment and planning really necessary? In appreciation of existing environmental and safety regulations, including the National Environmental Policy Act, air and water quality statutes, and the various occupational and mine health and safety regulations, the answer is yes.

What is more, it is possible that supplementary environmental impact statements may have to be prepared consistent with certain portions of development plans. However, when one views this expenditure of time and effort in terms of 1 ikely annual capital requirements and operating costs for a half million barrel per day industry estimated at nearly a billion dollars per year, a proper perspective for carefully reasoned development appears warranted. 
I strongly feel that the $X$-ray treatment of public scrutiny being imposed on domestic oil shale development will assure that the facts are known before full scale development, and not after all the hardware of this complex industry is piled high on the mesas of Colorado and Utah awaiting final approval of development plans.

Sherwin, M. B., and M. E. Frank. 1975. Chemicals from coal and shale: An $R$ and $D$ analysis for National Science Foundation. PB-243-393. (NTIS)

The report analyzes the economic and technical factors involved in the manufacture of primary organic chemicals such as olefins, aromatics, acetylene, ammonia and methanol from coal and shale. The technologies discussed are compared to present conventional technology which is based upon oil and natural gas. Chemical market demands and feedstock demands to the year 2000 are projected to estimate when coal and shale based processes would be required. The above inputs are utilized in outlining a research program which would insure the availability of this new technology. (NTIS)

Sweeton, F. H., and C. J. Barton. 1975. Estimated potential radiation dose from tritium in gasoline produced from oil shale by use of nuclear explosives. ORNL-TM-5017. (NTIS)

Recovery of $0 i 1$ from shale by use of nuclear explosives has been proposed. The principal radiological impact of this application of nuclear explosives would be expected to result from introduction of tritium into hydrocarbon products, including gasoline. The potential radiation dose that could result from tritiated gasoline is estimated by assuming that all gasoline used in the metropolitan Denver area in 1971 contained 5 microcuries of tritium per galion. The tritium would be converted to HTO and released from automobile exhausts at ground level. Traffic counts at various locations in the area together with a national average value for gasoline consumption was used to estimate tritium release rates in each of $400-\mathrm{km}^{2}$ areas into which the metropolitan area was divided. This information, together with annual average meteorlogical data from the Denver area, provided input to the AIRDOT computer code which calculates doses from dispersed atmospheric radioactivity releases. The estimated highest potential dose to a continuously exposed individual is $0.006 \mathrm{~m} \mathrm{Rem} / \mathrm{y}$ and the potential population dose to 1.06 million people living in the area is $2.3 \mathrm{man}-\mathrm{Rem} / \mathrm{y}$. These figures can be compared with the estimated background radiation dose from natural sources in Colorado of $164.6 \mathrm{~m}$ Rem/y which results in a population dose to 1.06 million people of $175,000 \mathrm{man}-\mathrm{Rem} / \mathrm{y}$. (NTIS)

Sylvester, R. D. 1975. List of Bureau of Mines publications and articlesJanuary 1, 1970 to December 31, 1974 with subject and author index. Bur. of Mines Special Pub. USDI Washington D.C. 555 pp. PB-252-843 (NTIS) 
Vandenberg, M. L. J. 1975. Some investigations on the chemical nature of kerogen. N75-2753/0S. (NTIS)

The kerogens of Green River oil shale (GRS) and Messel oil shale were studied to help determine the nature of the organic matter and the type of chemical reactions important in kerogen formation. Low temperature $(-78 \mathrm{C})$ ozonization was employed to obtain degradation fragments suitable for analysis. Since the kerogens exhibit enhanced reactivity in methylenechloride and methanol, these solvents were chosen for the experiments. The oxidation fragments of both kerogens show great similarity in carbon skeleton and functional groups. The degradation fragments of Messel include relatively more high molecular weight compounds and unsaturated structural elements than GRS. From the data obtained, the original contributing constituents are proposed to be relatively inert plant materials such as cuticles, waxes, and possibly sporopollenin. Possible explanations are presented for the above findings and the conclusions drawn from them. (NTIS)

Vysamyae, A. I. 1975. Experimental research on clarifying carcinogeneity of shale oil soot. PB-246-835. (NTIS)

The carcinogenic activity of soot and other atmospheric contaminants in biological tests was greater in direct proportion to the content in them of 3,4-benzapyrene. The question arose as to how shale soot or its extract of tarry substances induces tumors in the lungs. Experimental tests in mice and rats were conducted to study this problem. The report summarizes and discusses the implications for the etiology of lung cancer. (NTIS)

Wyoming Water Resources Research Institute Staff. 1975. An environmental reconnaissance study for Sweetwater County in situ oil shale research. Report for contract E(29-2)-3577.

Pursuant to conditions itemized in Contract Number E(29-2)-3577 between the United States Energy Research and Development Administration (ERDA) and the University of Wyoming as represented by the Water Resources Research Institute (WRRI) produced a five-chapter report titled "Environvironmental Reconnaissance Study for Sweetwater County In situ $0 i 1$ Shale Research". This document seeks to inform ERDA officials of the pertinent environmental regulations and requirements which must be satisfied before field operations can begin. Most of the pertinent rules and regulations are of recent vintage and often require specific interpretation for each project action.

Young, N. B., J. W. Smith, and W. A. Robb. 1975. Determination of carbonate minerals of Green River Formation $0 i 1$ shales, Piceance Creek Basin, Colorado. U.S. Bur. of Mines RI 8008. 
Quantification of carbonate minerals is important for the characterization of oil shale, particularly because of their thermal activity in production of oil from shale. The carbonate minerals found in this oil shale are nahcolite $\left(\mathrm{NaHCO}_{3}\right)$, dawsonite $\left(\mathrm{NaAl}(\mathrm{OH})_{2} \mathrm{CO}_{3}\right)$, Dolomite $\left(\mathrm{Mg}(1-\mathrm{x}) \mathrm{Fe}_{x} \mathrm{Ca}\left[\mathrm{CO}_{3}\right]_{2}\right)$, calcite $\left(\mathrm{CaCO}_{3}\right)$, and ferroan, $\left(\mathrm{Mg}(1-\mathrm{x}) \mathrm{Fe}_{x} \mathrm{CO}_{3}\right)$. While carbonate minerals can be removed by acid extraction from the balance of the oil shale, direct determination of carbonate minerals is complicated by the occurrence of the same cations in more than one mineral. A method for assigning the acid-soluble cations to the individual carbonate minerals was developed from two assumptions based on $0 i 1$ shale geochemistry: (1) calcite and ferroan do not occur together and magnesium is the same in dolomite and ferroan. These assumptions were tested by applying the technique for assigning cations to 219 samples from the saline section of the formation. The reported carbonate mineral amounts were compared statistically with $X$-ray diffraction peak heights, verifying the cation assignment method. (NTIS)

\section{4}

Burwe11, E. L., S. S. Tihen, and H.W. Sohns. 1974. Permeability changes and compaction of broken oil shale during retorting. U.S. Bur. Mines RI 7860 , $16 \mathrm{pp}$.

The Bureau of Mines conducted laboratory experiments to determine the change during retorting in the apparent permeability and the degree of compaction of beds of broken $0 i 1$ shale. Grades of $0 i 1$ shale studied ranged from 20.6 to 46.7 gallons of 011 per ton (gpt), and the simulated overburden pressures applied to the shale were from 300 to $900 \mathrm{psi}$. Linear regression analysis of the data produced equations describing the response of the oil shale. 0il shales of approximately $20 \mathrm{gpt}$ experience only minor apparent permeability reductions under test conditions, but richer shales (30 to $50 \mathrm{gpt}$ ) lose essentially all permeability. The permeability reductions were accompanied by corresponding decreases in bed height that ranged up to 37 percent of the original bed height. 7 refs. (NTIS)

Callahan, J. M. 1974. Shale 0il - mining and processing. Automotive Industries. 150(8): $36-38$.

One of the traditional approaches to mining, the underground method, is apparent at the Anvil Points 0il Shale Research Center. Other means are through the open-pit process.

Carlson, F. B., L. H. Yardumian, and M. T. Atwood. 1974. Toscoal process for low temperature pyrolysis of coal. Trans. Soc. Min. Eng. AIME 256(2): 128-131.

The $0 i 1$ Shale Corp. (TOSCO) is investigating the application of its $0 i 1$ shale retorting technology to coal processing in its 25-tpd retorting pilot plant. Low temperature char, with a high heating value, plus tar 
and gas have been produced from high moisture content, low heating value, subbituminous coal. The process, which has been named the TOSCOAL process, uses heated ceramic balls to provide the heat for retorting the coal. One ton of as-mined, subbituminous coal produces approximately $1 / 2$ ton of char, $1 / 2$ barrel of tar, and 1600 standard cubic feet (scf) of gas when the retorting is conducted at $970^{\circ} \mathrm{F}$. Properties and yields of the products are presented and compared with Fischer assay yields.

Colony Development Operation Staff. 1974. An environmental impact analysis for a shale oil complex at Parachute Creek, Colorado. Vol I. Part I. Plant Complex and Service Corridor. 349 pp.

This Environmental Impact Analysis has been prepared by and on behalf of Colony Development Operation in connection with the proposed construction of a commercial shale oil mine, plant, and related off-site facilities near Parachute Creek, Colorado. This analysis has been prepared as a comprehensive project document and includes a description and evaluation of the plant complex, the underground mine, a product pipeline from the plant to a connecting pipeline at Aneth, Utah, plant-related off-site facilities, utility and water supplies, and required socio-economic features. Underlying technical reports are included as appendices.

The four-part analysis is presented in three volumes together with a multivolume Appendix. More particularly, the volumes include the following matters:

Volume One of the analysis contains Part One and consists of a description of the construction and operation of the plant and mine, a detailed examination of the environment of the Parachute Creek Basin, an identification of the sources of environmental impacts related to this portion of the proposed activity, and a cumulative analysis of the effects of these impacts upon the local environment.

Colony Development Operation Staff. 1974. An environmental impact analysis for a shale oil complex at Parachute Creek, Colorado. Vol. II. Part II. Pipeline. $158 \mathrm{pp}$.

This Environmental Impact Analysis has been prepared by and on behalf of Colony Development Operation in connection with the proposed construction of a commercial shale oil mine, plant, and related off-site facilities near Parachute Creek, Colorado. This analysis has been prepared as a comprehensive project document and includes a description and evaluation of the plant complex, the underground mine, a product pipeline from the plant to a connecting pipeline at Aneth, Utah, plant-related off-site facilities, utility and water supplies, and required socio-economic features. Underlying technical reports are included as appendices. 
The four-part analysis is presented in three volumes together with a multivolume Appendix. More particularly, the volumes include the following matters:

Volume Two which includes Part Two describes the pipeline, the environment within the general vicinity of the proposed right-of-way, and the impacts which are expected to result from the construction and operation of the pipeline.

Colony Development Operation Staff. 1974. An environmental impact analysis for a shale oil complex at Parachute Creek, Colorado. Vol. III. Part III. SocioEconomic analysis off-site development and Part IV Conclusion. $236 \mathrm{pp}$. (III) and $19 \mathrm{pp}$. (IV).

This Environmental Impact Analysis has been prepared by and on behalf of Colony Development Operation in connection with the proposed construction of a commercial shale oil mine, plant, and related off-site facilities near Parachute Creek, Colorado. This analysis has been prepared as a comprehensive project document and includes a description and evaluation of the plant complex, the underground mine, a product pipeline from the plant to a connecting pipeline at Aneth, Utah, plant-related off-site facilities, utility and water supplies, and required socio-economic features. Underlying technical reports are included as appendices.

The four-part analysis is presented in three volumes together with a multivolume Appendix. More particularly, the volumes include the following matters:

Volume Three contains Part Three and Part Four. Part Three sets forth a general analysis of existing socio-economic conditions within the Colorado River Corridor from Grand Junction to Glenwood Springs. The analysis includes an evaluation of the off-site impacts which could result from potential settlement patterns of plant and mine employees and other employees attracted to the area by job opportunities in secondary service and commercial businesses. Part Four consists of a description of the land use plans and controls of the governmental authorities who will have jurisdiction over the proposed plant complex and pipeline and a cumulative evaluation of the overall impacts of the entire project as they relate to various public policies.

Cummins, J. J., F. G. Doolittle, and W. E. Robinson. 1974. "Thermal degradation of Green River kerogen at $150^{\circ} \mathrm{C}$ composition of products." U.S. Bur. Mines RI 7924, $18 \mathrm{pp}$.

The Bureau of Mines heated at $150^{\circ}$ to $350^{\circ} \mathrm{C}$ for 0.5 to 360 days Green River oil shale that had been previously extracted by benzene to provide information on in situ processing conditions, to determine the effect of low-temperature heating on the unconverted kerogen, and to determine the 


\begin{abstract}
composition of benzene-soluble thermal products. The methods used in determining the composition of the soluble thermal products consisted of fractionation of the soluble material, elemental analys is of the soluble products, fractionation of the polar resins by ion-exchange chromatography, gas chromatographic analysis of $n$-alkanes, and mass spectral analysis of the branched plus cyclic alkanes and aromatic oils, The methods used to determine the effect of low-temperature heating on the unconverted kerogen remaining in the oil shale heated residues consisted of carbon-hydrogen analysis, volatile material determination, carbon residue determination, and oxidation rate determination. In general, it was concluded that significant increases in the degradation of kerogen to $0 i 1$ occurred between the temperature range of $250^{\circ}$ to $350^{\circ} \mathrm{C}$; that the composition of the soluble products depends upon the temperature at which they are formed; and that the $\mathrm{n}$ alkanes are pyrolytically degraded from the kerogen structure. In particular, the $250^{\circ} \mathrm{C}$ heating temperature is beneficial to the formation of branched plus cyclic alkanes. Also, the heated and unconverted oil shale kerogen and the soluble thermal products become more aromatic as the temperature increases from $150^{\circ}$ to $350^{\circ} \mathrm{C}$.
\end{abstract}

Duval1, J. J., H. B. Jensen, and G. L. Cook. 1974. Kerogen conversion and transport of the shale-oil in a controlled state retort. Presented at Garden Conference on Fuel Science 8-12 July 1974 at New Hampton, New Hampshire.

In order to provide the necessary support to an in situ oil-shale retorting study, a controlled-state retort was developed by the Bureau of Mines allowing controlled gas flows, heating rates, and retorting zones through shale beds. This research retort is externally heated by electricity so that shale samples and oil samples may be taken at appropriate times during retorting. New information has been found on the dynamics of the rock-oil interface.

Frost, C.M., and P. L. Cottingham. 1974. Methods for refining crude shale oil produced by in situ retorting. U.S. Bur. Mines RI 7844, 21 pp.

Crude shale oil produced during in situ retorting by the Bureau of Mines at Rock Springs, Wyoming, was refined by three schemes. In the first, the crude $0 i 1$ was fractionated to raw naphtha and $400^{\circ} \mathrm{F}+$ residuum. The residuum was hydrogenated over cobalt molybdate catalyst at $815^{\circ} \mathrm{F}$ and $1,100 \mathrm{psig}$. The blended raw and $160^{\circ}-400^{\circ} \mathrm{F}$ hydrogenated naphthas were hydrodenitrified and then catalytically reformed. The $400^{\circ} \mathrm{F}+$ hydrogenated oil was catalytically cracked. In the second scheme, the crude was hydrogenated over nickel-tungsten catalyst at $800^{\circ} \mathrm{F}$ and $1,500 \mathrm{psig.} \mathrm{The}$ hydrogenated fractions were processed by methods used in the first scheme. The third scheme resembled the second but, prior to hydrogenation, the crude was "hydrostabilized" over cobalt molybdate at $500^{\circ} \mathrm{F}$ and $500 \mathrm{psig.}$ Yields of reformate and cat-cracked gasoline as volume-percents of the crude, and research-method octane numbers (with $3 \mathrm{ml} T E L$ ) for the three 
methods were as follows: First method, 32 pct reformate, 90 octane; 19.15 pct cracked gasoline, 99.2 octane. Second method, 29 pct reformate, 81.1 octane; 21.3 pct cracked gasoline, 99.6 octane. Third method, 28.2 pct reformate, 86 octane; 28.7 pct cracked gasoline, 95.9 octane.

Frost, C. M., R. E. Poulson, and H. B. Jensen. 1974. Production of synthetic crude from shale oil produced by in situ combustion retorting. Am. Chem. Soc. Sym. on Shale 0i1, Tar Sands and Related Fuel Sources. Preprint. 19(2): 156-168.

Hydrogenation tests made on the $600^{\circ}$ to $1,000^{\circ} \mathrm{F}$ heavy gas 011 from in situ crude shale oil showed that a nickel-molybdenum-on-alumina catalyst was superior to either cobalt-molybdenum-on-alumina or nickel-tungstenon-alumina catalysts for removing nitrogen from shale oil fractions. This nickel-molybdenum-on-alumina catalyst was used in the preparation of a synthetic crude oil by hydrogenation of various distillate fractions of an in situ crude shale oil. A high yield of premium refinery feedstock whose properties compared favorably to those of a "syncrude" described by the NPC was attained.

Geol. Soc. of Amer. Staff 1974. Development of oil shale in the Green River Formation. The Geologist, supplement to Vol. IX (4) 8 pp.

In the last two decades, U. S. petroleum demand has increased at a rate greater than that of domestic production. Concern has been expressed on the future of the Nation's energy supply if reliance must be placed entirely on increasing imports from foreign sources of questionable dependability. A domestic energy source that is under serious consideration to augment present supply is oil shale.

The Green River Formation in Colorado, Utah, and Wyoming represents a potential resource containing about 2 trillion barrels of oil in shale that averages 15 gallons per ton or more than 400 billion barrels in 30gallon-per-ton shale. This report considers the technological and environmental aspects of developing this resource for use by the people of the United States.

Gilmore, J., S., and M. K. Duff. 1974. Impacts of oil shale: boom or boon. Colo. Sch. Mines Quart. 69(2): 119-123.

Nationally, another 50 million people must be accommodated in the United States over the next 30 or 40 years. Nationally, continentally contained energy sources should be developed. Nationally, areas of unique environmental quality should be preserved.

Locally, the welfare (including the desired way of life) of people in the region should be defended. Locally, environmental and social standards should be maintained. Locally, the fruits of the booms should be shared equitably. 
0il shale development (and mineral fuels development in general) will require intensive planning. The planning should include land-use and growth management with careful selection of growth strategies.

0il shale development (and mineral fuels development in general) will generate immense cash flows in both the public and private sectors. The implementation of effective growth management, based on carefully selected growth strategies should be economically and socially selfsustaining so that the affected regions and their citizens find the development beneficial-a 20th century boon to all of us.

Glenn, W. E. 1974. 0il shale and the energy situation. Colo. Sch. Mines Quart. 69(2): 71-77.

To put self-sufficiency in meaningful terms, as a nation we could become self-sufficient by 1980 if we increased domestic oil and gas production 37 percent as compared to 1970 , and increased coal production 176 percent. That would mean 190,000 more 0il and gas wells and 9,000 coal mines in just 6 years.

But that's not all. Self-sufficiency by 1980 also means building 435 nuclear plants, 8 shale $0 i 1$ plants, 13 oil-from-coal plants, 30 gas-fromcoal plants and 19 geothermal plants. This undertaking would bring thousands of people into action and billions of dollars of hardware in operation.

Goodfellow, L., and M. T. Atwood. 1974. Fischer assay of oil shale procedures of the oil shale corporation. Colo. Sch. Mines Quart. 69(2): 205-219.

Fischer assay laboratory retorting procedures are used to estimate oil yields which would result from commercial processing of oil shale. When applied to analysis of cores, an economic evaluation of oil shale reserves can be carried out. The 0il Shale Corporation has also applied its techniques to producing complete material balances by collecting and analyzing product gas mixtures.

Equipment and techniques are discussed along with statistical parameters and application to monitoring large-scale, precommercial retorting operations.

Grant, B. F. 1974. Retorting oil shale underground-problems and possibilities. Colo. Sch. Mines Quart. 59(3): 39-46.

Heley, W. 1974. Processed shale disposal for a commercial oil shale operation. Mining Congr. J. 60(5): 25-29. 
Paper is concerned with the activities of Colony Development Operation, a joint venture operated by Atlantic Richfield Co. in western Colorado. Colony presently is in the construction engineering phase for a commercial complex to produce approximately 50,000 bbl per day of shale oil. This operation wil1 require about 66,000 tpd of rock to be produced from an underground room and pillar mine, crushing to a nominal of minus in., processing by the Tosco II retorting technique, and disposing of about 85 percent of the mass which remains after processing. Disposal of processed shale, the term applied to tailings from the Tosco II process, is the primary subject of our discussion here. The Tosco II technique removes essentially all of the kerogen material from the marlstone matrix by a thermal process involving a preheat stage, followed by addition of ceramic balls to gasify the hydrocarbon at a temperature in the range of $900^{\circ} \mathrm{F}$. In the process, the parent rock is reduced particles with over 30 percent passing the No. 325 sieve size. After retorting, the processed shale is cooled to about $200^{\circ} \mathrm{F}$ and moisture is added to it prior to further handling. The processed shale will be disposed of in a deep valley close to the mine and refining plant and subjected to vegetation, without any environmental hazards. Schematic diagram of the operation is shown. 7 refs. (NTIS)

Hendrickson, T. A. 1974a. 011 shale processing methods. Colo. Sch. Mines Quart. 69(2): 45-69.

Hendrickson, T. A. 1974b. Shale oil - process choices. Chem. Eng. (NY) 18(10): 66-69.

A rundown on some of the routes being groomed for production of shale oil. One of these, the Tosco II process, is already considered proven and is on the verge of commercialization.

Hughes, E. E., E. M. Dickson, and R. A. Schmidt. 1974. Control of environmental impact from advanced energy sources. PB-239-450. (NTIS)

The technology and environmental effects associated with production of energy from new or advanced sources are reviewed. These include solar, geothermal, oil shale, solid wastes, underground coal gasification, and hydrogen energy sources. Projections to the year 2000 of levels of energy production from the first four of these sources are presented. Environmental impacts on air and water quality, and land use are derived per unit of energy. Levels of pollutant emissions and other environmental effects of the development of these advanced energy sources are projected. Impacts likely to require control measures are identified. Subjects for research and development directed toward control of environmental impacts are recommended. These recommendations are incorporated into a research and development plan. Approximate priority assignments 
derived from consideration of the timing of development and the importance and degree of definition of the identified environmental effects are given. (NTIS)

Jacobson, I. A., Jr., A. W. Decora, and G. L. Cook. 1974. Retorting indexes for $0 i 1$ shale pyrolyses from ethylene - ethane ratios of product gases. U.S. Bur. Mines RI. 7921.

In a closely controlled laboratory retorting system for oil shale, a relationship was developed by the Bureau of Mines between the temperature in the retort and the weight ratio of ethylene to ethane in the gases produced. Reciprocal temperature was shown to be directly proportional to the $\log ([$ ethylene $] /[$ ethane $])$. From this relationship a number, called retorting index, was developed. The retorting index has the dimension of temperature, but its magnitude depends on both temperature and residence time for the reactants in the heated zone in the oil-shale retort. The slopes of the lines relating reciprocal temperature and the logarithm of the ethylene-ethane ratios are nearly constant for each of the retorting processes for which data have been presented. The retorting index should be a valuable tool to control the operation of oil-shale retorts, either above ground or in situ. If an optimum operating condition can be established, the maintenance of the optimum or the departure from it should be easily monitored by use of the index.

Kate11, S., and P. Wellman. 1974. Economic analysis of oil shale operations featuring gas combustion retorting. U.S. Bur. Mines Tech. Prog. Rep. 81: $18 \mathrm{p}$.

This report is primarily involved with the economics of producing a highquality, semirefined shale oil (Syncrude) from oil shale. The study envisions two options for Syncrude production, 50,000 and 100,000 barrels per calendar day, with an integrated system of underground mining, aboveground processing, and waste handling. The 50,000-barrel-per-day complex wi11 require a capital investment of $\$ 279,450,100$ (excluding 1 and cost) and will provide a discounted cash flow (DCF) rate of 12 percent at a Syncrude selling price of $\$ 5.66$ per barrel. The large complex will require a capital investment of $\$ 522,375,400$, but the Syncrude selling price declines to $\$ 5.15$ per barrel to yield the 12 percent DCF. 2 refs. (NTIS)

Kirkpatrick, L. W. 1974. Air pollution aspects of proposed oil shale development in northwestern Colorado. Colo. Sch. Mines Quart. 69(2): 103-107.

Besides the question of carcinogens, the ability of proposed oil shale processes and communities to meet existing state and federal ambient air quality standards is questionable. In Garfield and Rio Blanco Counties, the state standards for particulate matter and sulfur oxides are 45 and 
15 micrograms per cubic meter, respectively. I doubt the standards will tolerate the amount of industrial activity and community growth now proposed for the Piceance Basin and adjacent areas. Our enforcement section will have to deny "authority to construct" unless the standards can be met. The ability to meet ambient air standards must be analyzed using air pollution predictive models. Also, the commission may choose to reconsider its ambient air quality standards. The decision on standards will be difficult since the present standards are designed to keep the surrounding mountains visible and the air somewhat clear. A key question is: Do the citizens of that area and of the state want to sacrifice the present particulate matter standards, hence air clarity, to help relieve a national energy problem?

Livingston, C. W. 1974. 0il shale - a solution to the roadblock. Eng. Min. J. 175(6): 109-117.

There can be little question that full-scale development of a U. S. shale oil industry has been blocked because it has been impossible to develop the resources of a vast area of shale oil deposits by conventional concepts of mine layout and mine development.

The technology outlined in this article largely overcomes the "horrendous problems of the environment" recognized by Assistant Interior Secretary Hollis Dole, and it also reduces both direct costs and environmental costs for producing oil from shale.

Taken collectively, the plan is complex. However, reduced to its essential elements, it becomes simple. Each of the elements of the new blasting technology that make the proposed solution possible has already been demonstrated for blasts up to $20,000 \mathrm{yd}$.

The roadblock to oil shale development need not continue. To perpetuate such an attitude of defeatism would deny the U. S. one of its greatest assets.

Marsha11, P. W. 1974. Colony Development Operation, room-and-pillar oil shale mining. Colo. Sch. Mines Quart. 69(2): 171-184.

Colony's pilot mine and semiworks plant engineering test programs were completed in the fall of 1972 and commercialization of oil shale was deemed realistic. Since that time, Colony efforts have been directed toward evaluation of the data collected during the semiworks operations, and in designing a commercial plant.

Colony's objective is to develop a commercial oil shale plant. As an indication of the degree of seriousness about this project, the company at present is spending over a million dollars a month on engineering 
planning, detailed engineering, environmental work, and the many other aspects in proceeding with a project of this magnitude. Environmental Impact Analyses (EIA) have been submitted to the Bureau of Land Management (BLM) to obtain permits for the processing facilities and for a pipeline right-of-way permit. This pipeline permit application covers a thoroughly studied, 192-mile pipeline route from the proposed plant site on upper Parachute Creek to an existing pipeline at Lisbon, Utah.

Meyer, J. W., W. J. Jones, and M. M. Kessler. 1974. Energy supply, demand/ need and the gaps between. Vol. II. Monograph, working papers, and appendix papers. PB-243-977. (NTIS)

This report contains a number of working papers and monographs written in non-scientific language for the general public describing the state-ofthe-art and possibilities of several alternatives for helping in the near- and iong-term energy crisis. (NTIS)

Miller, J. S., and R. T. Johansen. 1974. Fracturing oil shale with explosives for in situ recovery. Am. Chem. Soc., Div. Fuel Chem. Preprint 19(2): 60-85.

Three different explosive fracturing techniques developed by the Bureau of Mines for preparing oil shale for in situ recovery on eight experimental sites near Rock Springs, Wyoming, are discussed. The fracturing procedures included displacing and detonating nitroglycerin in natural or hydraulically induced fracture systems, displacing and detonating nitroglycerin in induced fractures followed by wellbore shots using pelletized TNT, and detonating wellbore charges using pelletized TNT. The research on oil shale formations demonstrated that nitroglycerin displaced into natural or hydraulically induced fractures could be detonated with the resulting explosion propagating through the explosive-filled fracture. Sufficient fragmentation was obtained to sustain an in situ combustion experiment by these procedures. Detonating nitroglycerin in fracture systems and pelletized TNT in wellbores of various well patterns at 100$\mathrm{ft}$. depth developed extensive rock fragmentation, thereby achieving interwell communication suitable for in situ recovery experimentation. In the experiments reported the shale was fragmented by this method, and a successful underground retorting experiment to recover shale oil was performed. 19 refs. (NTIS)

Moussavi, M., D. K. Young, and T. F. Yen. 1974. Correlation of oil shale particle size to rate of dissolution of mineral matrix. Am. Chem. Soc., Div. Fuel Chem. Preprint 19(2): 300-305.

Experimental investigations are reported in which the kinetics of the dissolution process of oil shale were studied as function of its mesh size. The shale rock was crushed and sized into three ranges, 42/60, 
$60 / 100$, and 150/200. Since the effect of bioleaching is essentially that of dilute acid reaction with the carbonate material, hence for better accuracy in monitoring the acid concentration reagent grade hydrochloric acid was used instead of the acid produced by the sulfur oxidizing bacteria. The rate of dissolution of the carbonate mineral was followed by direct measurement of the weight loss and by atomic absorption measurement. Experimental results are discussed in terms of possible dissolution mechanisms. 7 refs. (NTIS)

Pforzheimer, H. 1974. Paraho - New prospects for oil shale. Chem. Eng. Prog. 70(9): 62-65.

February, 1976 is the scheduled completion target for the privately financed, 30-month research and development project-the Paraho 0il Shale Demonstration-currently under way at the Anvil Points 0il Shale Experiment Station of the U. S. Bureau of Mines near Rifle, Colorado. Its objectives are to demonstrate the use of the Paraho processes and hardware in retorting $0 i 1$ and gas from oil shale, to obtain data, and to prepare a preliminary feasibility study of a commercial plant. The selected minable seams shown are of $0 i 1$ shale deposits at least $30 \mathrm{ft}$. thick and averaging 30 gal. of oil per ton of shale. These seams represent sufficient reserves to feed a $1.5 \mathrm{million}$ bbl./day oil shale industry for 100 years. This article's purpose is to describe the demonstration, as well as the background leading to its present status. 2 refs. (NTIS)

Ridley, R. D. 1974. In situ processing of oil shale. Colo. Sch. Mines Quart. 69(2): 21-24.

Processing of oil shale in its existing formation-referred to as in-situ processing-has long been the dream and hope for large-scale oil production from this nation's immense oil shale reserves. The advantages were obvious. Mining of the ore and the total materials handling would be dramatically less, spent shale would be left underground, the costs would have to be less, and-as a result-lower grade ores could be processed economically. The latter point alone would increase the recoverable reserves by several times over more conventional mining and aboveground processing systems. Until recently the disadvantage was also obvious-no one had successfully demonstrated a method which had any prospect for high yields and low costs, the essential keys to commercial success. For as most of you know, oil shale is not a porous rock nor is it found in permeable formations. It is this factor, almost alone, which has caused the failure of most in situ tests. Most conventional fracturing techniques have been tried in an attempt to create adequate flow paths for gas and oil between even closely spaced wells. Some met with limited technical success, such as being able to maintain combustion in tight fractures, and produce some 0i1. But in no known attempt was gas flow even partially controllable and oil yields were essentially negligible. 
Rold, J. W. 1974. Colorado's involvement in solving environmental problems of oil shale development. Colo. Sch. Mines Quart. 69(2): 85-91.

We all now realize that government, industry and total society face an immense energy shortage. The potential shale oil target is of such tremendous magnitude (600 billion barrels in beds rich enough and thick enough to be mined and processed with present technology), that it assumes not only economic but worldwide strategic importance. Economic return and the societal demand for this resource is so great that I am convinced that adequate environmental guidelines can be set, and that technology can evolve to meet those guidelines. Obviously, we do not yet have all the answers to the environmental problems. Many answers cannot come until we have an evaluation and a monitoring program of actual mining and retorting operations. That information will provide additional technological answers to both known and unforeseen technical and environmental problems. After beginning at a neutral position, and objectively evaluating all the information available to me in the past $41 / 2$ years, I believe that the economic and strategic incentive is large enough and that the standards are stringent enough to provide both adequate environmental protection and a sizeable shale oil supply. More information is now available, and more study and evaluation of potential environmental impacts of oil shale development have now been made than any other comparable industrial development in the history of mankind. The State of Colorado can be justly proud of its role in that program.

Schora, F. C. Jr., H. L. Feldkirchner, P. B. Tarman, and S. A. Weil. 1974. Shale gasification under study. Hydrocarbon Process 53(4): 89-91.

General considerations of the possibility of production of synthetic natural gas (SNG) and liquid hydrocarbons from oil shale by direct hydrogeneration are followed by a description of laboratory thermobalance tests and bench-scale tests. Design of process development unit (one ton per hour) and concept of a commercial unit are presented by flow sheets. Reactor design details are discussed. 3 refs. (NTIS)

Schora, F. C. Jr., H. L. Feldkirchner, P. B. Tarman, and S. A. Weil. 1974. Conversion of oil shale by controlled hydrogasification. Conf. on Nat. Gas Res. and Technol, 3rd, Proc. Sess., Pap., Dallas, Texas, March 6-8, 1974 Sess. 4, Pap. 2: $11 \mathrm{p}$.

A new process has been developed for converting oil shale to pipeline gas by direct hydrogasification. This process uses countercurrent shale/ hydrogen contacting and excess hydrogen. Laboratory- and bench-scale tests have demonstrated that as much as 95 percent of the organic matter in the shale can be converted to useful products. Along with the results obtained thus far, the design of a 1 ton per hour process development unit is discussed as well as commercial process concepts. 3 refs. (NTIS) 
Smith, C. D. 1974. Unique approach to get oil shale out of the ground. Min. Eng. (NY) 26: 52-56.

Paper describes the geology of the Piceance Creek Basin, Colorado, oil shale deposit and presents a proposed surface mining system after partial removal of the overburden. Theoretical financial calculation for production of 500,000 bpd is included. (NTIS)

Smith, J. W., and K. Futa. 1974. Direct determination of organic hydrogen in oil shales by low-temperature ashing. Chem. Geol. 14: 31-38.

Direct determination of the organic hydrogen content of oil shales was achieved using low-temperature ashing to separate organic hydrogen from the rock. This organic hydrogen content, particularly useful in characterizing the organic materials in oil shales and other sediments, has been available only by laborious and indirect procedures. Treatment of a sample with the low-temperature asher (LTA) oxidizes organic hydrogen into water which is recovered and weighed. Four oil-shale samples representing the two major deposits of the United States of America were used to demonstrate the method. Directly determined organic hydrogen values compare favorably to the indirect values available on the demonstration samples. Mineral hydrogen contents can also be determined after LTA treatment by analyzing the organic-free residue. This method should be easily extended from oil shales to other organic-bearing sedimentary rocks.

Trude11, L. G., T. N. Beard, and J. W. Smith. 1974. Stratigraphic framework of Green River Formation oil shales in the Piceance Creek Basin, Colorado. Rocky Mt. Assn. of Geol. 1974 Guidebook. p. 65-70.

A previously reported time-stratigraphic framework suitable for evaluating stratigraphic changes in the deeply buried oil shales of the Piceance Creek Basin was developed by correlating lithologic and oil-yield data. This Bureau of Mines report summarizes the major features of the framework and explains some of the terminology applied to the Green River Formation. In cores from the central part of the basin, three major lithologic zones are recognizable: (1) a basal freshwater shale unit equivalent to the Garden Gulch and Douglas Creek Members; (2) a middle unit, the Parachute Creek Member, composed of dolomitic oil shales; and (3) an upper clastic unit, the Evacuation Creek Member. (Ed. Note: The Evacuation Creek Member has recently been assigned to the Uinta Formation by Cashion and Donnel1, 1974). The Parachute Creek Member contains the major part of the oilshale resource. In the north-central part of the basin the lower part of the Parachute Creek Member includes an evaporite sequence characterized by a unique suite of saline minerals. The timestratigraphic framework is essential for understanding the vertical and lateral variability of the oil shale resource and the distribution of the saline minerals. 
Tyler, A. L. 1974. Procedure for the estimation of carbon oxidation rates in porous spent oil shale. UCID-16602. (NTIS)

The rate of consumption of oxygen in the oxidation of carbon residues in porous particles of spent oil shale can be estimated from the free stream oxygen concentration and temperature. The procedure consists of calculating the reaction rate based on the free stream parameters and applying a correction which is the actual reaction rate within the porous particle divided by the rate evaluated at the free stream temperature and oxygen concentration. (NTIS)

Weichmann, B. 1974. The Superior Process for development of oil shale and associated materials. Colo. Sch. Mines Quart. 69(2): 25-43.

0il shale containing nahcolite and dawsonite can be processed into low sulphur fuel oil, natural sodium bicarbonate, soda ash and aluminum compounds. Nitrogen and elemental sulfur may also be produced as by-products if partial refining is included in the process.

These products could be called environmental products because their use would result in a net enhancement of the environment. This integrated process can be a closed-cycle, noncontaminating operation with minimum disturbance and maximum benefit. Processing all three minerals simultaneously offsets the individual costs of each product, thus making the total process more economically desirable than development for shale oil only.

The Superior process can most conveniently be shown as a six-step operation, including underground mining, underground crushing and nahcolite separation, retorting and partial refining, aluminum and sodium compound recovery and underground spent shale disposal. (auth)

Weil, S. A., H. L. Feldkirchner, and P. B. Tarman. 1974. Hydrogasification of oil shale. Am. Chem. Soc., Div. Fuel Chem. Preprint 19(2): 123-146.

This is a report on a study which was initiated to investigate the technical and economic feasibility of producing synthetic pipeline gas from oil shale by hydrogasification, using countercurrent gas-solids contacting and excess hydrogen. In the bench-scale tests, using concurrent hydrogen/shale contacting, the authors were able to gasify about $65 \%$ of the organic carbon in the 0 il shale. About $15 \%$ was converted to light aromatic liquids, and about $20 \%$ remained in the spent shale. The major variable controlling the conversion of organic matter to gas was the hydrogen/shale ratio. Results of the study are summarized. The experimental program has shown that the basic concept of countercurrent operation is technically feasible. The overall chemistry of the system is now better defined and looks very favorable. 4 refs. (NTIS) 
Zitting, R. T. 1974. Solid Fuels; Their contribution to energy independence. Am. Min. Congr. Min. Conv/Expo., Preprint., Las Vegas, Nev., October 7-10, 1974. Mining Congr. J. 6.(2): 42-44.

There is no energy shortage in the U. S. A. only petroleum is in short supply. Solid fuel, especially coal, is in abundance, so are uranium and oil shale. Artificial obstacles have to be removed from the way of the electrical generating industry so it can expand, raise money, and invest in energy production toward independence.

\section{3}

Anders, D. E., and W. E. Robinson. 1973. Geochemical aspects of the saturated hydrocarbon constituents of Green River oil shale - Colorado No. 1 core.

U. S. Bur. Mines RI 7737: 23 pp.

Saturated hydrocarbons from 60 selected samples of a 2,300-foot Green River Formation oil-shale core (Piceance Creek Basin, Colo.) were analyzed by gas/liquid chromatography techniques. Emphasis was placed upon the distribution of normal alkanes and 15 key-branched and cyclic alkanes. the latter compounds consisted of the $C_{15}, C_{16}, C_{18}, C_{19}$, and $C_{20}$ Chain isoprenoids, the $5-\alpha$ and $5-\beta C_{27}, C_{28}$, and $C_{29}$ steranes, three $C_{30}$ pentacyclic triterpanes, and perhydro- $\beta$-carotene. The results showed definite evidence of maturation of both the n-alkanes and the branched and cyclic alkanes; however, most if not all of the changes were limited to the indigenous soluble extract and were not the result of additional soluble extract generation from the insoluble kerogen. Source material and environmental variations were important factors in some of the observed differences in the branched plus cyclic alkane compositions.

Atwood, M. T. 1973. Production of shale 0i1. Chemtech: 617-621.

In this article, the author covers the chemical nature of oil shale, the oil shale reserves in the tri-state area of Utah, Wyoming, and Colorado, and the production of shale oil from the oil shale rock. 11 refs.

Barker, L. K., and P. L. Cottingham. 1973. Refining improvement of shale-0il naphtha. U.S. Bur. Mines RI 7740: $15 \mathrm{pp}$.

The purpose of this research was to determine how much, if any, improvement would be made by subjecting hydrogenated shale-oil naphtha to a catalytic reforming process. Preselected ranges of temperature and pressure within the commercial reforming ranges were chosen for investigation and other possible variables were held constant. All tests were made with a liquid hourly space velocity (LHSV)) of 3 volumes of liquid feed per volume of catalyst per hour $\left(V_{f} / V_{c} / h r.\right)$ and a hydrogen feed rate of $3,000 \mathrm{scf} / \mathrm{bbl}$. Operating temperatures of $850^{\circ}, 875^{\circ}$, and $900^{\circ} \mathrm{F}$ were used at pressures of 200,400 , and 600 psig. The greatest octane improvement in the naphtha was obtained at a temperature of $900^{\circ} \mathrm{F}$ and pressure 
of $200 \mathrm{psig}$. The reformed naphtha had a clear research octane number of 89 , a liquid yield of 80 vol. pct., and a yield-octane number of 71.1 . The data indicate that a higher temperature could have produced a higher yield-octane number.

Borg, I. 1973. Reconnaissance of the oil shale resources of the Piceance Creek basin, Colorado from the standpoint of in situ retorting within a nuclear chimney. UCRL-51329. (NTIS)

New isopach maps are presented, given the thickness of continuous sections of oil shale averaging $15 \mathrm{gal} /$ ton and $20 \mathrm{gal} / \mathrm{ton}$ in the Piceance Creek basin. They differ from maps produced heretofore in that 1) they are based on a larger number of assayed wells and coreholes (202) and 2) lean or leached zones are included in the so-called "continuous sections" of a particular yield if the average of the whole section equals or exceeds the stipulated yield. Overburden maps are shown which give the depth of burial to the top of the 15-gal/ton, 20-gal/ton sections and to the top of the Mahogany marker, or A-groove if the marker was not located. These are not normalized to a "regional stream gradient" and therefore more nearly represent average overburden thicknesses in the basin.

Burwe11, E. L. 1973. In situ retorting of $0 i 1$ shale; results of two field experiments. U. S. Bur. Mines RI 7783.

Cottingham, P. L., and L. K. Barker. 1973. Depleted uranium as catalyst for hydrocracking shale 0i1. Ind. and Eng. Chem. Product Research and Dev. 12(1): 41-47.

The preparation and testing of two depleted uranium oxide catalysts for use in hydrocracking crude shale oil were reported. The objectives of the hydrocracking experiments were to convert high boiling shale oil into gasoline-boiling-range products and to eliminate sulfur and nitrogen from the gasolines produced.

Ellington, R. T. 1973. Fluidized bed retorting of oil shale. Trans. Soc. Min. Eng. AIME 254: 264-169.

The fluidized bed is an effective method for investigating retorting phenomena and possibly a commercial means of retorting oil shale. Both were examined by Sinclair $0 i l$ (now part of Atlantic Richfield Co.) in the period 1965-1968. The results of the work show that the presence of an oxidizing environment during retorting results in loss of oil yield which indicates that vapor phase oil burns in preference to combustion of coke on spent shale. Consideration of hardware indicates that there are several possibilities for commercial embodiment. As a companion to shafttype retorts the fluidized bed could have good potential. Realistic assessment of costs suggests that further development may have to wait commercialization of another process. 9 refs. NTIS. 
Frost, C. M., and H. B. Jensen. 1973. Hydrodenitrification of crude shale oil. Div. of Petrol. Chem., ACS, 18(1): 119-128.

The present study was made to determine the effects of processing variables on the rates at which various types of nitrogen compounds are removed from crude shale $0 i 1$, and to determine if the effects of these processing variables could be used to explain the disagreement in the literature. For these studies a flow-type reactor was used under steady state conditions. Low space velocities were used to attain low nitrogen levels in the hydrotreated products at temperatures considerably below the normal shale oil hydrocracking temperatures.

Livingston, C. W. 1973. Control blasting. U. S. Patent 3735704.

Disclosed herein is a new concept in blasting which is based on a unique theory that permits total utilization of the energy of a blasting charge. The method of this invention enables one, through a set procedure, to control the direction and distance of placement of huge volumes of earth and/or the degree of breakage of a volume of material adjacent the area effected by the blast. The method requires systematic test blasts to determine parameters for use in established formula so that the desired end of control blasting of huge volumes of earth can be attained. The scope of this invention is unlimited in its application to mining, hydropower development, construction projects, etc.

Pitman, J. K., and J.R. Donnel1. 1973. Potential shale-oil resources of a stratigraphic sequence above the Mahogany zone, Green River formation, Piceance Creek Basin, Colorado Jour. Res. U.S. Geol. Survey 1(4): 467-473.

In the southern part of the Piceance Creek basin the upper part of the Green River Formation above the Mahogany zone contains beds of rich oil shale which may be economically recoverable by a surface-mining operation. Four units within this sequence were evaluated for thickness, distribution, oil yield, and potential shale-oil resources. In the area appraised, total estimated resources of 128.5 billion bbl of $0 i 1$ are contained within the sequence. It is thickest in T.3S., R.96 W., where 354 feet of oil shale yields an average of $14 \mathrm{gal}$ of $0 i 1$ per ton, with a total resource of 9.0 billion bbl. It is richest in T.5S., R. $96 \mathrm{~W}$. , where 250 feet of $0 i 1$ shale yields an average of 19 gal of oil per ton, with a total resource of 6.5 billion bbl. Resources are tabulated for four units of the sequence.

Smith, J. W., and W. A. Robb. 1973. Aragonite and the genesis of carbonates in Mahogany zone oil shales of Colorado's Green River Formation. U. S. Bur. of Mines RI 7727: 14pp.

Aragonite, co-occurring with calcite and dolomite as matrix minerals, has been discovered in Mahogany zone oil shales of Colorado's Eocene Green River Formation, posing puzzles on the geochemical patterns of their 
separate origins, reasons for their simultaneous existence, and their interrelation. The presence of aragonite is demonstrated by $X$-ray diffraction. Amounts of aragonite and dolomite are significantly and inversely related, but the calcite quantity is essentially independent of either aragonite or dolomite quantity. A geochemical pattern outlining the deposition conditions that created the Green River Formation oil shale is postulated from characteristics of the oil shale. The development of the three separate carbonates--aragonite, calcite, and dolomite--the inverse relationship between aragonite and dolomite, and the independence of amounts of calcite and the other two carbonates are shown to be natural consequences of this oil-shale genesis pattern.

\section{2}

Anon. 1972. Extraction of energy fuels. PB-220-328. (NTIS)

The purpose of the research is to identify and implement the most promising set of research programs in the energy field. The technical assessment contained in this report is an initial appraisal of the following functional areas: (I) Stimulation of petroleum and natural gas production, (II) production of oil from tar sands, (III) development of oil shale, (IV) underground gasification of coal, (V) $0 i l$ and gas production from organic wastes, and (VI) primary extraction of coal. The report covers short-term needs (1972-80), intermediate-term needs (1975-85), and longterm needs (1980-2000). (NTIS)

Anon. 1972. 0il shale - a statewide answer to petroleum shortage. Min. Eng. of AIME 24(10): 95-98.

A review from an engineer's point of view.

Barney, J. H. et a1. 1972. Process for retorting oil shale in the absence of shale ash. U. S. patent 3691056.

In the pyrolysis of oil shale to shale oil, the loss of the shale oil product by sorption on porous shale ash in the pyrolysis zone is prevented by attriting the shale ash particles to fines and elutriating the fines from the heat carrier circuit so that the heat carriers recycled to and used in the pyrolysis zone are substantially free of shale ash.

Cummins, J. J., and W. E. Robinson. 1972. Thermal degradation of Green River kerogen at $150^{\circ}$ to $350^{\circ} \mathrm{C}$. Rate of product formation. U. S. Bur. Mines RI 7620, $15 \mathrm{pp}$.

Green River oil shale previously extracted by benzene was heated at $150^{\circ}$, $200^{\circ}, 250^{\circ}, 300^{\circ}$, and $350^{\circ} \mathrm{C}$ for 0.5 to 360 days to determine the rate at which kerogen degrades to thermal products, the types of thermal products 
formed, and the effect of prolonged low-temperature heating (preheating) upon subsequent assay yields. Thermal decomposition of kerogen at $150^{\circ}$ to $350^{\circ} \mathrm{C}$ is treated as a first-order reaction. The specific reaction rate for kerogen decomposition increases from $2.2 \times 10^{-4}$ per day at $150^{\circ} \mathrm{C}$ to $2.0 \times 10^{-1}$ per day at $350^{\circ} \mathrm{C}$. The calculated kerogen activation energy is $19 \mathrm{kcal}$. Variations in the rate of formation of individual type components of the pyrolytic products were found. Carbon balances show an increase in the amount of kerogen converted to bitumen and oil (from assay of preheated oil shale) as the temperature of preheating increased from $150^{\circ}$ to $350^{\circ} \mathrm{C}$. Total product from shale preheated at temperatures of $150^{\circ}$ and $200^{\circ} \mathrm{C}$ gave less than 100 percent of Fischer assay yields while the total products from shale preheated at temperatures of $250^{\circ}$ to $350^{\circ} \mathrm{C}$ gave greater than 100 percent of Fischer assay yields.

Dana, G. F., and J. W. Smith. 1972. 0 il yield and stratigraphy of the Green River Formation's Tipton Member at Bureau of Mines site near Green River, Wyoming. U. S. Bur. of Mines RI 7681.

$0 i 1$ yields, lithology, and stratigraphy have been evaluated for 15 cored wells and two sampled wells representing 10 square miles of the Tipton Member of the Green River Formation near Green River, Wyoming. The area evaluated is being used by the Bureau of Mines for experimental production of oil from the oil shales in place. Lithology and oil yields were correlated to produce a stratigraphy diagram for the in situ study area, permitting precise designation of comparable sections. Because of lateral uniformity of oil shale, oil yields from eight cores and two sets of drill-cutting samples within a quarter section show the range of variation in average oil yield arising from experimental error. Variation in average oil yields from the seven cores representing the 10-square-mile study area lies within the expected experimental error. No difference in oil-shale richness across the study area is indicated.

Average oil yields for three Tipton sections in the study area were determined as follows: (1) The entire Tipton Member oil shale (about 145 feet thick), 13.3 gallons per ton; (2) the 40-foot upper rich zone, 21.0 gallons per ton; and (3) the 21-foot zone in which the Laramie Energy Research Center is conducting in situ experiments, 22.4 gallons per ton. One acre of the 21-foot experimental section represents 34,300 barrels of $0 i 1$ in place, and 1 acre of the Tipton's 40-foot rich upper layer represents 62,000 barrels.

Herkenhoff, E. C. 1972. When are we going to mine oil? Eng. Min. J 173(6): 132-138.

Precarious state of energy supply in this country calls for examination of hitherto unexploited sources of fuels. Paper points out that there exist 383 shallow (less than 900 feet deep) oil fields plus deposits of oil sand and oil shales all of which could and should be exploited by surface mining combined, wherever necessary, with hot water processing. Preliminary economics for a domestic operation are analyzed. NTIS. 
Katell, S., and P. Wellman. 1972. 011 shale as a potential energy source. Am. Chem. Soc., Div. Fuel Chem., Preprint 16(1): 61-72.

Technological and economic aspects are discussed which are related to the possibility of conversion of oil shale to a synthetic crude oil, which can be accomplished by various systems including mining development and general mining plan, primary crushing and screening plant; secondary and tertiary crushing and screening plants; briquetting plant and retorting plant; refinery of crude $0 i 1$, and capital investment and financial analysis. 2 refs. NTIS.

McDermott, J. 1972. Liquid fuels from oil shale and tar sands. Liq. Fuels from 0 il Shale and Tar Sands. Noyes Data Corp., Park Ridge, NJ, 267 pp.

The information in this book is based on U. S. patents since 1960 relating to the production of liquid fuels from oil shale and tar sands. The research and development in this area has been very extensive over the years and has largely been conducted by the major petroleum companies. The book describes 101 processes on the retorting and refining of oil shale and the separation of oil from tar sands. Indexes by company, inventor and $U$. S. patent number are provided. NTIS.

Smith, J. W., L. G. Trudell, and W. A. Robb. 1972. 011 yields and characteristics of Green River formation oil shales at WOSCO EX-1, Uintah County, Utah. U.S. Bur. Mines RI 7693.

Detailed oil yield, lithologic, and mineral distribution data are presented for core and drill-cutting samples from the Western 0il Shale Corp. Project Utah EX-1 Corehole (WOSCO EX-1), drilled to sample a deeply buried oilshale sequence in the Green River Formation of Utah's Uinta Basin. Drilling of this corehole was part of the evaluation of this site for possible oil-shale development by nuclear explosion. Sections sufficiently thick for nuclear development average 15 gallons per ton or less and consist predominantly of low-grade shales. Some properties of low-grade shales may be advantageous to a nuclear experiment by facilitating breakage, fracture development, and in situ retorting. The formation correlates precisely with the well studied oil shales 25 miles east near the Colorado border. A 235-foot mineralized section containing nahcolite, shortite, and searlesite whose bottom lies 200 feet above the Mahogany zone is described.

Zambas, P. G., G. R. Haworth, F. W. Brackebusch, and J. B. Sellers. 1972. Large-scale experimentation in oil shale. Trans. Soc. Min. Eng. AIME 252(3): 283-289.

Results of large-scale mining experimentation carried on in Stage I of the Anvil Points $0 i 1$ Shale Research Program, Rifle, Colorado, are reported. 
After a new adit was excavated, over 500,000 tons of $0 i 1$ shale was extracted during a 13-month period by a modified room and pillar method. Experiments in drilling and blasting headings, benches, and crosscuts are reported. Roof-bolting procedures, loading and hauling, and ventilation design are discussed. Results of the extensive investigations carried out by the cooperative industry group and earlier work by the U. S. Bureau of Mines indicate that mining oil shale is technologically feasible. 2 refs. NTIS.

1971

Beck, B. L. 1971. Analytical laboratory techniques for oil shale. Western Society of Soil Science.

Mobile 0il Corporation and five other major oil companies jointly participated in an oil shale research program at Anvil Points near Rifle, Colorado from 1964 to 1967. An analytical laboratory was established to support this research program. The operation and problems were probably typical of any such remote location. Two analytical chemists plus four to seven trained-on-site technicians carried out the analytical work. About twentyfive procedures were used to provide the required data. Included among these were a semi-automatic multiple Fischer Assay, mineral $\mathrm{CO}_{2}$, precision carbon-hydrogen, gas analysis, and rigorous sampling. The heterogenous samples - shale, both liquid and gaseous retort products - were of major concern. Thorough documentation of samples and results were required for al1 participating companies. Detailed record books and color-coded report forms were found beneficial. To keep aware of accuracy and precision of data, a systematic quality control program was used throughout the project. This was supplemented with synthetic and standard samples, and crosscheck programs with other laboratories. Results from analyses of several hundred samples yielded some useful correlations among the various tests on raw oil shale and shale oil.

Holm, M. M. 1971. Hydrogen production from a kerogen-depleted shale formation. U. S. patent 3605890 .

A process for producing a hydrogen-rich gas which comprises injecting steam into a kerogen-depleted shale formation through an injection well; contacting the steam with carbonaceous matter in the shale formation at a temperature between about $600^{\circ} \mathrm{F}$ and $1,100^{\circ} \mathrm{F}$ to obtain a hydrogen-rich gas, at a temperature between about $600^{\circ} \mathrm{F}$ and $1,100^{\circ} \mathrm{F}$ and with a relatively small amount of $\mathrm{CO}$ in the hydrogen-rich gas, the $\mathrm{CO}_{2}$ to $\mathrm{CO}$ ratio being at least 2.5; and withdrawing the hydrogen-rich gas from the shale formation through a production well; said kerogen-depleted shale formation having a volume of at least $1 / 2$ million cubic feet of kerogen-depleted shale. 
Jacobson, I. A. Jr. 1971. Thermal reactions of 1-methylindole. U.S. Bur. Mines RI 7529.

The thermal reactions of 1-methylindole were studied in the temperature range of $525^{\circ}$ to $627^{\circ} \mathrm{C}$ in a flow reactor. The major products consisted of 2-methyl indole, 3-methyl indole, indole, quinol ine, hydrogen, and methane. 2-Methylindole is formed from 1-methylindole by an irreversible isomerization reaction. The 2-methylindole isomerizes in a reversible manner to 3-methylindole, the equilibrium favoring the 3-methyl isomer. Indole is formed directly from 1-methylindole. Quinoline is formed from 1-methyl indole, 2-methylindole, and 3-methyl indole.

Jensen, H. B., R. E. Poulson, and G. L. Cook. 1971. Characterization of a shale-0il produced by in situ retorting. Am. Chem. Soc., Div. Fuel Chem. Preprint 15(1): 113-121.

This paper described two crude shale oils that were recovered from successful in situ-combustion retorting experiments. The description was based primarily on the results of the application of the Bureau of Mines crude shale-oil analysis to these two crudes. In addition to describing the properties of the two in situ crudes in terms of this analysis, the properties of crude shale oils from the aboveground retorts were also described. Comparison of the oils from the aboveground retorts with each other were made in order to determine the effect of change of retorting parameters upon $0 i 1$ character. Comparison of the in situ oils with the abovegroundretort oils allowed explanation of the retorting conditions under which the in situ oils were produced. This indirect approach to the problem of describing the conditions under which in situ retorting is accomplished was necessary because of the inaccessability of the retort zone to visual inspection, either during or after retorting.

Kate11, S., and P. Wellman. 1971. Mining and conversion of oil shale in a gas combustion retort. U. S. Bur. Mines Tech. Prog. Rep. 44, 11 pp.

Several systems have been proposed for the production of synthetic crude oil from oil shale. An economic analysis of one proposed system is presented in this paper. An oil shale complex to produce 100,000 bb1/calendar day for semirefined crude oil will require a capital investment of $426,216,400$ dollars. This investment includes mining, retorting, intermediate pipelining, and partial refining. A selling price of 3.74 dollars per barrel of product will be necessary to maintain a discounted cash-flow rate of $12 \%$. NTIS. 
Cameron, R. J., and J. L. Dailey. 1970. The international synthetic fuels picture. Colo. Sch. Mines Quart. 65(4): 24-40.

This review of the international synthetic fuels picture, al though not intended to be exhaustive, will attempt to outline the current situation as we know it with some thoughts on the future. Since several recent reviews adequately treat the situation in this country, our primary aim will be to bring you up to date on synfuel activities outside the United States, especia?ly where industries are in being or where prospects appear encouraging.

Campbe11, G. G., W. G. Scott, and J. S. Miller. 1970. Evaluation of oil-shale fracturing test near Rock Spring, WY. U.S. Bur. Mines RI 7397.

Bureau of Mines research to develop an in situ retorting recovery method for $0 i 1$ shale has involved field testing of fracturing techniques for creating fluid-flow paths in impermeable oil shale. Electrolinking, hydraulic liquid explosive were tested in a 25-ft-square, five-spot pattern. These wells were drilled into oil shale at 50-to 88-ft depths near Rock Springs, WY. Results of the fracturing tests were evaluated by injecting air into a test well and measuring flow rates and flow profiles in adjacent test wells before and after each test. To identify points of air entry (location of fractures) in wells, flow profiles were determined by use of inflatable packers and by continuous logging with an airflow probe developed during the fracturing program. Electrolinking and hydraulic fracturing without sand propping were relatively ineffective; hydraulic fracturing with sand propping created horizontal fractures with desirable flow capacity; and fracture flow capacity was significantly increased by detonation of nitroglycerin displaced in the natural and hydraulically induced fracture systems.

Chambers, P. S. 1970. Bureau of Mines researches way to oil shale developments. Petrol/Chem. Eng. 42 (2): 28, 30, 32-3 and 36 .

The Federal Government, through the Bureau of Mines, has been investigating oil shale and shale oil since 1944. Majority of the work is handled through the Laramie, Wyoming research center, located adjacent to campus of the University of Wyoming. Topics investigated include characteristics and conversion of oil shale and shale oil. Much of the retort work underway is designed to test the technical feasibility of and outline the conditions for using nuclear devices to break up the shale. Waste disposal and pollution control are problems that the Bureau has only begun to investigate. NTIS.

Chenevert, M. E. 1970. Shale alteration by water absorption. J. Pet. Tech. 22: 1141-1148. 
An absorptional isotherm technique makes it possible to define quantitatively the hydrational tendencies of any formation, thereby eliminating the cumbersome rock classification schemes presently used in industry.

Cook, E. W. 1970. Thermal analys is of oil shales. Colo. Sch. Mines Quart. 65(4): $133-140$.

To obtain oil from oil shale, it is necessary to heat the shale. To state this is to carry shale to Green River, but it does focus heat and heat transfer as central to the technology of oil shale development. For our present purposes, we will only be concerned with heat requirements. Al though a knowledge of heat requirements for retorting oil shale is important, surprisingly few studies have been reported. The most extensive were by the Bureau of Mines, which were invaluable during preliminary studies. However, much of the work was empirical, so few generalizations could be safely made.

It was believed that a rational study would enable one to predict with some confidence heat requirements under a variety of circumstances.

Donnel1 J. R., and R. W. Blair, Jr. 1970. Resource appraisal of three rich oil-shale zones in the Green River Formation, Piceance Creek Basin, Colorado. Colo. Sch. Mines Quart. 65(4): 73-87.

The main oil-shale-bearing member of the Eocene Green River Formation, the Parachute Creek Member, contains several distinct rich oil-shale zones that underlie large areas of Piceance Creek Basin in northwestern Colorado. Three of these have been selected for an oil-shale resourceappraisal study, covered in paper. The three rich oil-shale zones have total resources of 317 billion barrels of $0 i 1$ in the areas appraised. (NTIS).

Johnson, D. R., and J. W. Smith. 1970. Bureau of Mines apparatus for therma 1 analysis; simultaneous DTA-TG-EGA for oil shale and solid fuels. U. S. Bur. Mines RI 7429.

Apparatus providing simultaneous differential thermal analysis, thermogravimetry, and evolved gas analysis, has been developed by the Bureau of Mines specifically for thermal study of oil shale and other natural fuels. The apparatus is described in detail, and simultaneous analyses on a thermal analysis demonstration compound, calcium oxalate monohydrate, are presented to demonstrate the instrument's capabilities.

Rammler, R. W. 1970a. The retorting of coal, oil shale, and tar sand by means of circulated fine-grained heat carriers as a preliminary stage in the production of synthetic crude 0il. Colo. Sch. Mines Quart. 65(4): 141-167. 
Numerous processes are available for the production of crude oil from coal, oil shale or tar sand. A process sequence which is suitable for all three starting materials includes a retorting step to produce oils, which are subsequently hydrogenated. The present paper deals with an efficient modern retorting process, which has been commercially utilized for the flash carbonization of coal and has been tested in technical-scale experiments using oil shale and tar sand.

Rammler, R. W. 1970b. One process retorts, three feeds for synthetic crude. Min. Eng. (NY) 22(9): 63-66.

A detailed description of a retort in process which can be economically and advantageously used as a preliminary stage in the making of synthetic crude oil. Known as the Lurgi-Ruhrgas process, the technique has proven commercially successful in the carbonization of coal and has also been thoroughly tested for its performance in distilling oil shale and tar sand on the pilot plant level. These tests and their results are fully discussed. NTIS.

Schramm, L. W. 1970. Mineral Facts and Problems. In Bureau of Mines Shale 0 i1 Bu11. U.S. Dept. of the Interior 650: 185-202.

Topical review.

\section{9}

Bae, J. H. 1969. Some effects of pressure on oil shale retorting. Soc. Petroleum Eng. J. 9(3): 287-292.

A series of batch-type retorting experiments at $930^{\circ} \mathrm{F}$ were performed to investigate the effect of pressure and surrounding atmosphere on the retorting of oil shale. The experimental pressure ranged from atmospheric to 2,500 psig. The sweeping gases used were $\mathrm{N}_{2}, \mathrm{CO}_{2}, \mathrm{H}_{2} \mathrm{O}, \mathrm{NH}_{3}$ and $\mathrm{H}_{2}$.

We found that high pressure reduces the oil yield significantly and produces a larger volume of light hydrocarbon gases. The crude shale oil obtained at high pressure has higher aromaticity and a lower pour point than the low pressure material. The sulfur and nitrogen content in shale oil does not change significantly with increasing pressure.

The effect of sweeping gas is usually small. In general, gases which decompose to yield $\mathrm{H}_{2}$ ncrease the oil yield at high pressure. At atmospheric pressure there is no effect. The high oil yield with $\mathrm{H}_{2}$, more than 100 percent of the Fischer Assay, reported on "hydrotorting" experiments was not observed in this work.

Dayton, S. H., and D. Carthew. 1969. 0il shale will demand efficient materials handling. SAE-Paper 690364 for meeting Apr. 15-16: 10 pp. 
Given state of shale technology, initial large-scale mining efforts will be by quarry room and pillar method; use of sand fill support system would permit eventual mining of pillars; other possilbe techniques may be block caving, strip mining, or shrink stopes, in situ retprting may be possible with nuclear detonations: high-voltage electrofracturing, explosives fracturing, and pneumatic fracturing are discussed; known characteristics of major oil-bearing shale fields are presented. 12 refs.

Voegeli, P. T., and R. U. King. 1969. Occurrence and distribution of molybdenum in the surface water of Colorado. Geological Survey Water-Supply paper 1535-N U. S. Government printing office, Washington D.C.

Molybdenum was detected in 89 percent of the samples collected from all the principal colorado streams and their chief tributaries and from a few reservoirs and lakes. Amounts detected ranged from 1 to 3,800 micrograms per liter. The greatest amounts of molybdenum detected were in samples from the Colorado River at the below Kremmling, the Dillon Reservoir, the Blue River below Dillon Dam, the Eagle River, and Tenmile Creek.

Williams, F. E., P. L. Russell, and M. J. Sheridan. 1969. Potential applicatons for nuclear explosives in a shale-oil industry. U.S. Bur. Mines Info. Circ. 8425: $37 \mathrm{pp}$.

Nuclear detonation data were accumulated, studied, and evaluated by the Bureau of Mines to visualize how nuclear explosives might be used in a shale-oil industry. The evaluation shows that the Green River Formation at the semi-isolated locale of Piceance Creek Basin, in northwestern Colorado, is thick and widespread enough to warrant consideration of nuclear mining in lieu of conventional methods. Because cost data for nuclear explosions are limited, cost comparisons are made largely by assumptions. Also described are the history of the shale-oil industry, the geology and size of oil-shale resources, and conventional mining methods and processing technology.

\section{8}

Barnes, A. L., and R. T. Ellington. 1968. A look at in situ oil-shale retorting methods based on 1 imited heat transfer contact surfaces. Colo. Sch. Mines Quart. 63(4): 83-108.

Mathematical analysis of in situ retoring of oil shale in deposits containing wells interconnected by vertical fractures is used for economic analysis of limited heat transfer surface systems. Hot gas is injected into the fracture to supply the necessary sensible heat and of retorting. 
The thermal conductivity and thermal capacity of the oil shale and endothermic heat losses due to chemical reaction were taken to be temperaturedependent. The vertical fractures were considered to be of finite height. Vertical conduction of heat into the zone above and below the fracture was not considered; however and estimate of the error resulting from this omission was made. The effects of temperature of the injected gas, injection rate, system geometry, cyclic injection, and time upon retoring efficiency were investigated.

Results from this study show that the rate of retoring oil shale around the fracture is a direct function of both injection temperature and rate, and the theoretical air-oil ratio at the producting well is an inverse function of temperature. Retorting rates are constant until "breakthrough" of the $700^{\circ} \mathrm{F}$ isotherm at the producing well, assuming constant injection parameters. Retorting rates for bounded systems are higher than the analogous unbounded systems and air-oil ratios are less. The use of an alternating injection-soak routine with high injection rates is less efficient than continuous injection at lower rates.

Analyses based on the mathematical analysis show that under optimum conditions this type is situ process could be economically marginal at best. Heat transfer from vertical fractures should be superior to that from systems of more limited ares such as those comprised entirely of well bores. Becuase of this, it is concluded that the economics of in situ processes using even more limited surface areas would be uneconomical. This work supports the conclusion that in situ oil shale retorting research should be directed toward processes conducted in multifractured or broken-up matrix systems.

Dinneen, G. U., K. E. Stanfield, G. L. Cook, and H. W. Sohns. 1968. Developments in oil-shale technology. Chemical Engineering Progress Symposium Series 64(85): 15-21.

The existence of enormous oil-shale resources in the Green River Formation of Colorado, Utah, and Wyoming (estimated at two to three trillion barrels of $0 i l$ in place) and the constantly expanding energy needs of the country have led, during the last several years, to a high level of effort to utilize this resource. This paper will discuss only the technological aspects of this effort. Much information has been gained about the origin of the Green River Formation, the minerals present in it, the reactions of kerogen, and the composition of shale-oil. Two major developmental efforts have been underway with the sequence of mining, crushing, and aboveground retorting used to produce shale-oil. An attractive alternative to this sequence is in situ retorting. Various approaches to this method are being studied, and some results have been published. A novel approach in this area is a proposal for an experiment to use a nuclear device to fracture large quantities of shale. Background data for such an experiment are being obtained. 
Linden, H. R. 1968. The case for synthetic pipeline gas from coal and $0 i 1$ shale. Chem. Eng. Prog. 64(8): 57-72.

At the present time and in the foreseeable future, utility fuel gas will consist primarily of methane and will have a heating value of about $1,000 \mathrm{Btu} / \mathrm{std}$.cu.ft. It is a premium fuel. Presently, it meets nearly one-third of the requirements for energy in the United States and is used primarily as a source of heat.

At present, the utility fuel gas being used in almost entirely natural gas. But, just as electricity can be produced from such sources as coal, natural gas, 0il, nuclear energy, and water power, so can methane be produced from a wide variety of source materials. The proved reserves of natural gas and expected ultimate recoveries will be sufficient to supply our requirements economically for many years to come.

1967

Cashion, W. B. 1967. Geology and fuel resources of the Green River formation, southeastern Uinta Basin, Utah and Colo. U.S. Geol. Sur. Prof. Paper 548.

The Green River Formation has been divided, in ascending order, into the Douglas Creek, Garden Gulch, Parachute Creek, and Evacuation Creek Members. The Douglas Creek Member is composed chiefly of sandstone, siltstone, and algal and oolitic limestone deposited in a nearshorelacustrine environment. It interfingers with the underlying wasatch Formation toward the former shore and interfingers with the overlying Garden Gulch and Parachute Creek Members toward the former basin. The Garden Gulch, Parachute Creek, and Evacuation Creek Members are composed chiefly of thin-bedded marlstone, siltstone, and oil shale deposited in a lacustrine environment. The Parachute Creek Member contains the principal oil-shale beds of the Green River Formation. The richest of these beds is the Mahogany oil-shale bed, which lies within a group of rich oil-shale beds that are designated as the Mahogany ledge at the surface and as the Mahogany zone in the subsurface. The Evacuation Creek Member of the Green River Formation is overlain by and interfingers with the Uinta Formation of Eocene age.

Hill, G. R., and P. M. Dougan. 1967. The characteristics of a temperature in situ shale 0i1. Colo. Sch. Mines Quart. 62(3): 75-90.

A $40^{\circ}$ A.P.I. crude shale oil has been produced from the Green River Formation in the Piceance Creek Basin of Colorado by injection of hot natural gas at a controlled temperature. The quality of the shale oil differs very markedly from the customary shale oil from the same formation produced in a high temperature retort. The characteristics of the oil fractions have now been determined. These include distallation analyses, viscosity, and pour point determination. 
Hi11, G. R., D. H. Hohnson, L. Miller, and J. L. Dougan. 1967. Direct production of a low pour point high gravity shale-0i1. Ind. and Eng. Chem. Product Research $6(1): \quad 52-59$.

Test of a concept of the energy required to heat the rock and convert the kerogen to a mobile oil could be provided by heated natural gas. The hydrocarbons in the natural gas would serve as a compatible solvent for the $0 i 1$ and would penetrate the pores and fissures produced as the converted kerogen moved out of its original sites because of its thermal expansion and volatility. The temperature of the heated natural gas could be high enough to produce the desired kerogen decomposition but low enough to minimize endothermal decomposition of the carbonate minerals of the marlstone matrix and the fusion of these minerals which occurs in combustion-type, high temperature processes. Absence of oxidizing gases minimizes polymerization reactions.

The laboratory experiments and an in situ experiment in the Piceance Creek Basin of Colorado have given data suggesting the following mechanisms for conversion of kerogen to $0 i 1$.

Kerogen $K_{1}$ bitumen $K_{3}$ oil + gas + residue

$$
\kappa_{3} \text { polymer } K_{4} 011^{\prime}+\text { gas }+ \text { residue (1) }
$$

Melton, N. M., and T. S. Cross. 1967. Fracturing oil shale with electricity. Colo. Sch. Mines Quart. 62(3): 45-61.

Based upon positive results obtained in laboratory and mine-tunnel experiments, a test site 7-1/2 miles west of Rock Springs, WY, was selected for a larger scale field experiment. Fracturing tests were conducted in four shallow wells drilled in the oil-shale formation. Some new permeable zones were created but, in general, the induced permeability between wells was not up to desired levels. In an attempt to improve the induced permeability, two conventional nitroglycerin well bore shots were detonated in one of the wells. Air-injection tests made after the detonations showed appreciable improvement.

Schlinger, W. G., and D. R. Jesse. 1967. Hydrotorting - use of hydrogen for improved recovery of shale oil. Colo. Sch. Mines Quart. 62(3): 133-140.

The recovery of the shale oil generally consists of three major phases; (1) mining and transporting the crude $0 i 1$ shale to the primary processing site, (2) extraction of the shale oil from the large fraction of ash and foreign material in the raw shale and (3) refining the crude shale oil to marketable products. Each of these steps is a major operation and contributes significantly to the cost of obtaining finished products from oil shale. 
The following discussion will be directed primarily toward the second of these phases, however some discussion as to how the second and third phases can be combined will be presented.

Use of hydrogen permits recovery of shale oil in yields far in excess of the Modified Fischer Assay. It has been demonstrated that yields in excess of 120 to 125 percent of the Fischer Assay can be realized.

Smith, J. W., and D. R. Johnson. 1967. Thermal analysis of natural fuels. In: Proc. of the 2nd Toronto Sym. on Thermal Anal. p. 95-116.

The natural solid fuels - coals, oil shales, and black shales - constitute present and potential sources of fossil fuel energy. Thermal degradation of many materials in this group also generates valuable products - coke and coal tar from coal types, and shale oil from oil shales and some black shales - so that the thermal properties of natural fuels largely determine their value. Application of thermoanalytical techniques to evaluating the thermal characteristics of natural fuels, however, presents problems not solved with the usual DTA and TG equipment. During their study of oil shales the U.S. Bureau of Mines developed thermoanalytical equipment and techniques to overcome the particular problems presented by natural fuels. This apparatus is described, together with its application to a study of natural fuels, particularly oil shale from the Green River Formation.

1966

Bradley, W. H. 1966. Tropical lakes, copropel, and oil shale. Geol. Soc. Amer. Bu11. 77: 1333-1338.

During a long-continued study of the lacustrine beds of the Eocene Green River Formation, I have tried to interpret past events from observation of present-day processes. After a search of some 40 years, four lakes have been found that are producing a kind of organic ooze judged to be a modern analogue of the precursors of rich oil shale. Two of the lakes are in central Africa and two are in Florida. A11 four are shallow. The ooze in all four is predominantly algal, entirely in the form of minute fecal pellets, and does not decay in warm, wet, oxidizing environments.

Several of the most unusual, mummified micro-organisms found in the oilshale of the Green River are illustrated as testament to the inference that the organic oozes also were resistant to decay. Studies to determine why these algal oozes do not decay are in progress, but as yet no satisfactory explanation is available.

Lekas, M. A. 1966. Economics of producing shale oil, the nuclear in situ retorting method. Colo. Sch. Mines Quart. 61(3): 91-114. 
It appears that nuclear in situ retorting can be applied successfully to lower grade shale, having an oil content as low as 15 gallons per ton. Producing costs for this. shale are estimated to range from 48c per barrel for a 1,000-foot-thick bed to $\$ 1.16$ per barrel for a 400 foot-thick bed. Estimates have been made that crude shale oil produced at a cost of $\$ 1.25$ per barrel in western Colorado could be marketed profitably in California.

The economic utilization of this technique in the lower grade shales would greatly increase the potential scope of its application. Essentially the entire Piceance Creek Basin of western Colorado, containing one trillion barrels of shale oil, appears to be economically amenable to its use, and the possibilities of commercial application to oil shale deposits in Utah and Wyoming are enhanced.

Sohns, H.W., and H. C. Carpenter. 1966. In-situ oil shale retorting. Chem. Eng. Prog. 62(8): 275-278.

Studies of the properties of Green River oil shale and their effects on a possible in situ shale oil recovery operation, and the deductions and calculations that can be made from pertinent laboratory research and published information on in situ recovery of petroleum indicate that it may be practical to recover shale oil by an in situ combustion process. The major differences between an in situ petroleum operation and a similar oil shale operation are due to the nature of the organic material and to the absence of permeability in shale.

Judging by petroleum experience and the results of preliminary laboratory test, permeability can be created by various means; however, since laboratory tests cannot duplicate the natural rock stresses and the variations in rock properties occuring in oil shale deposits, the response of oil shale beds to fracturing techniques can be determined only by controlled field tests. Results of these tests would be used to guide subsequent fracturing of a selected oil shale interval for an actual in situ recovery project.

Both of the in situ techniques that have been successfully employed in petroleum recovery could probably be used for the recovery of oil from shale; however, in view of predictable advantages and disadvantages of both, it seems probable that a combination of the two might be most feasible. Results of field experiments should provide solutions to most of the problems encountered and provide the basis for determining the economic feasibility of an in situ shale $0 i 1$ recovery process.

1965

Ert1, T. 1965. Mining Colo. $0 i 1$ shale. Colo. Sch. Mines Quart. 60(3): 83-91. 
The contemplated oil shale throughput of a single plant has risen from 5,000 tons a day to present expectations of 60,000 to 100,000 tons a day. Part of the reason for the change is the practical confirmation that oil shale can be mined from a large room of which the roof is supported by pillars, comparable to a quarry with a roof. Because of the uniformity and regularity of the deposit it lends itself to large-scale, low-cost mining.

No longer does one expect to begin mining the entire Mahogany Ledge section as a unit. To repeat the history of most mineral deposits the richest portion will be mined first. The richest portion in the region northerly of Grand Valley extends from a roof a few feet below the wellknown Mahogany Marker to a floor about 36 feet below the marker. The initial oil shale room then may be a little over 30 feet high.

Hubbard, A. B. 1965. Automated modified fischer retorts for assaying oil shale and bituminous materials. U.S. Bur. Mines RI 6676, 19 pp.

Automatic control instruments were utilized by the Bureau of Mines for routine assays of large numbers of oil shale samples and other bituminous materials. The standard Fischer assay method was automated by automatically controlling the heating cycles of a battery of 12 electric heaters with electronic controllers and programers. The condensers were cooled with a modified automatically controlled refrigeration bath. The complete assembly consisted of 12 retort units, necessary control instruments, and the refrigeration bath. This equipment was capable of producing more consistent results than those previously obtained with the gas-heated retorts and of increasing the output of assays substantially with no increase in operating personnel.

Lekas, M. A., and H. C. Carpenter. 1965. Fracturing $0 i 1$ shale with nuclear explosives for in situ retorting. Colo. Sch. Mines Quart. 60(3): 7-30.

Accumulated data on the effects of underground nuclear explosions, and research by the USBM on the high temperature behavior of $0 i 1$ shale, have made the nuclear in situ extraction process appear much more attractive today than it was six years ago.

These developments can be summarized as follows:

1. Better understanding of the mechanism of rock fragmentation by nuclear explosions in various rock types.

2. Qualitative understanding of the extent of permeable fractures extending beyond fragmented areas.

3. Development of small diameter nuclear explosives of low fission to fusion ratio that can be emplaced in drill holes. 
4. Development of dependable formulae for predicting the general effects of underground explosions.

5. Better understanding of the retorting characteristics of oil shale.

Sarapuu, E. 1965. Underground electrocarbonization of oil shale. Colo. Sch. Mines Quart. 60(3): 193-200.

It has been demonstrated that the electrical pyrolysis progresses outward from each electrode until these zones finally merge and create a continuous fixed carbon path between the two electrodes. This zone has a high electrical conductivity in comparison to the surrounding strata and therefore the carbonization of $0 i 1$ shale takes place in this area.

Williamson, D. R. 1965. 0il shales: V $0 i 1$ shale retorts. Colo. Sch. Min. Miner. Ind. Bu11. 8(2): 16.

Pertinent basic data about the character of kerogen and of oil shales, and about conversion of kerogen to usable materials were presented in preceding issues of the Mineral Industries Bulletin. The present issue is a summary of information about retorts and retort design. Details are far too voluminous for inclusion, hence a list of selected references is retort educt is generally not included al though its problems affect retort design and operation.

\section{4}

Anon. 1964. Colorado $0 i 1$ Shale Symposium Indicates Industry is Ready to Move. Eng. Min. J. 165(6): 103-109.

A review from industry's point of view.

Carver, H. E. 1964. Conversion of oil shale to refined product. Colo. Sch. Mines Quart. 59(3): 19-38.

Scopes Union $0 i 1$ Co's 1955-1958 oil shale operations.

Grant, B. F. 1964. Retorting oil shale underground-problems and possibilities. Colo. Sch. Mines Quart. 59(3): 39-46.

The process by which shale oil might be produced by retorting the oil shale in place - sink wells as in conventional petroleum recovery, we have chosen to call underground retorting. One method for doing this is illustrated in Figure 1. Wells are drilled to the shale bed and a horizontal fracture created between wells to provide a pass for injected and 
produced fluids. A burner is operated in the injection well to start combustion in the shale bed. The burning zone then is moved outward from the injection well at a controlled rate while heat flows by conduction from the burning zone to adjacent oil shale. The hydrocarbons produced by pyrolysis flow into the stream of gaseous combustion products and are swept through the fracture system into producing wells.

The apparent simplicity of the concept is nidleading. Very complex heat transfer problems are involved. The pyrolysis reactions of kerogen under the conditions of inplace retorting need to be defined. The effect of the thermal environment through which the products of pyrolysis must travel to reach a producing well is of equal concern. The engineering problems of ignition and combustion control also are formidable. Unfortunately, relatively little of the information available on aboveground retorting can be applied to the underground process.

Concern with in-place retorting and its problems is justified at this time. Over most of the Piceance Basin the oil shale lies at depths that make mining expensive. Moreover, in-place retorting may produce shale $0 i 1$ cheaper than mining and aboveground retorting.

Guthrie, Sr., B. 1964. 011 from rock-the gas combustion process. Colo. Sch. Mines Quart. 59(3): 7-18.

After gaining experience with the several retorting processes, and after observing numerous other methods in their development stage, Bureau of Mines engineers concluded that: (1) countercurrent flow of shale and the heating medium was desirable; (2) internal-combustion processes generally were the most thermally efficient; (3) cold shale should be used to cool the hot combustion retort gases, thus eliminating high water consumption and preventing coke-like formation in the recovery system; (4) sensible heat from retorted shale should be recovered, thus discharging cool, spent shale; and (5) the retort gas and/or carbon residue on the retorted shale should supply all heat required for retorting.

Based on these parameters, all efforts were devoted to developing a countercurrent, gravity-flow, and internal combustion retorting method. Time does not permit a detailed discussion of all the techniques investigated or experiments conducted. It wi11 have to suffice to say that during the experimentation program, purely by chance, a set of conditions were selected that seemed to favor the formation of a stable oil mist, the results of which were so encouraging that an a11-out effort was made to perfect what was to be termed the Gas-Combustion Process.

Williamson, D. R. 1964a. 0il Shales IV: Retorting and other beneficiation of oil shales. Colo. Sch. Mines Miner. Ind. Bul1. 7(6): 1-12.

Hydrocarbons have so commonly been extracted from $0 i 1$ shales by heating them that the word retorting has displaced beneficiation within the 
industry. This is a disservice because application of heat is only one of several procedures which already are being used for converting or separating kerogen. One or more of the alternate procedures may be preferable eventually for converting the organic material to merchantable products even though they have been used thus far only for analys is and research. None of them yet seem to hold any promise that this traditional position may be changed in the future, but some are certain to be usable in related activities if not for production of shale oil. Retorting, consequently, is pointedly presented in this issue of the Bulletin as only the most important of the possible beneficiation procedures.

Williamson, D. R. 1964b. 0il shale (V): $0 i l$ shale retorts. Colo. Sch. Mines liner. Ind. Bul1. 8(2): 1-15.

Pertinent basic data about the character of kerogen and of oil shales, and about conversion of kerogen to usable materials were presented in preceding issues of the Mineral Industries Bulletin. The present issue is a summary of information about retorts and retort design. Details are far too voluminous for inclusion, hence a list of selected references is included to assist further search. For the sake of brevity, treatment of retort educt is generally not included although its problems affect retort design and operation.

\section{2}

Bendoraitis, J. G., B. L. Brown, and L. S. Hepner. 1962. Isoprenoid hydrocarbons in petroleum. Isolation of $2,6,10,14$ - tetramethylpentadecane by high temperature gas - liquid chromatography. Anal. Chem. 34: 45-53.

A saturated isopreniod residue, 2,6,10,14 - tetramethylpentadecane (pristane), was isolated from petroleum by high temperature gas-liguid chromatography and identified by mass, infrared, and proton magnetic resonance spectroscopy. On a total crude basis, this hydrocarbon represents $0.5 \%$ of the East Texas and $0.2 \%$ of the Mid-Continent crudes from which it was isolated. The occurrence of pristane at an abnormally high concentration level in petroleum corroborates current theories regarding the origin of petroleum from natural source material. The most likely precursor of pristane is the phytol component of chlorophyll.

Jaffe, F. C. 1962a. 0il shale Part I: Nomenclature, uses, reserves, and production. Colo. Sch. Mines Miner. Ind. Bul1. 5(2): 1-11.

Jaffe, F. C. 1962b. 0il shale Part II: Geology and mineralogy of the oil shales of the Green River Formation, Colo., Utah, and Wyo. Colo. Sch. Mines Miner. Ind. Bu11. 5(3): 1-16.

In a previous Mineral Industries Bulletin on oil shale (Volume 5, Number 2) the nature of different oil shales and related, oil-yielding, sedimentary 
rocks was described. Known oil-shale reserves of the major districts were indicated, and oil-shale exploitation in several countries of the free world and the communist bloc was briefly reviewed. In this study, of general nature, the conclusion was reached that oil shales are a raw material of significant and rapidly increasing importance, and that they can be mined, retorted, and refined under favorable economic conditions.

$\underline{1961}$

Donnel1, J. R. 1961. Tertiary geology and oil shale resources of the Piceance Creek basin between the Colo. and White River. U.S. Geol. Surv. Bul1. 1082-L.

The area of the Piceance Creek basin between the Colorado and White Rivers includes approximately 1,600 square miles and is characterized by an extensive plateau that rises 1,000 to more than 4,000 feet above the surrounding lowlands. Relief is greatest in Naval 0il-Shale Reserves Nos. 1 and 3 near the south margin of the area, where the spectacular Roan Cliffs tower above the valley of the Colorado River.

The oldest rocks exposed in the mapped area are sandstone, shale, and coal beds of the Mesaverde group of Late Cretaceous age, which crop out along the east margin of the area. Overlying the Mesaverde is an unnamed sequence of dark-colored sandstone and shale, Paleocene in age. The Ohio Creek conglomerate, composed of black and red chert and quartzite pebbles in a white sandstone matrix, is probably the basal unit in the Paleocene sequence. The Wasatch formation of early Eocene age overlies the Paleocene sedimentary rocks. It is composed of brightly colored shale, lenticular beds of sandstone, and a few thin beds of fresh-water limestone. The wasatch formation interfingers with and is overlain by the Green River formation of middle Eocene age.

The Green River formation has been divided into the Douglas Creek, Garden Gulch, Anvil Points, Parachute Creek, and Evacuation Creek members. The basal and uppermost members, the Douglas Creek and Evacuation Creek, respectively, are predominantly sandy units. The two middle members, the Garden Gulch and Parachute Creek, are composed principally of finer clastic rocks. The Anvil Points member is present only on the southeast, east and northeast margins of the area. It is a nearshore facies composed principally of sandstone and is the equivalent of the Douglas Creek, Garden Gulch, and the lower part of the Parachute Creek members.

A11 of the richer exposed oil-shale beds are found in the Parachute Creek member, which is divided into two oil-shale zones by a series of lowgrade oil shale-beds. The upper oil-shale zone has several key beds and zones which can be traced throughout most of the mapped area. One of these, the Mahogany ledge or zone, is a group of very rich oil-shale beds at the base of the upper oil-shale zone. Drilling for oil and gas in the northeastern part of the area has revealed rich oil-shale zones in the Garden Gulch member also. 
Local unconformities within and at the base of the Evacuation Creek member are exposed at several places along Piceance Creek and at one place near the mouth of Yellow Creek; otherwise, the rock sequence is conformable.

The mapped area is the major part of a large syncline, modified by numerous smaller structural features. Fractures, probably associated genetically with the minor structural features, are present in the central part of the area. These fractures are high-angle normal faults with small displacement. They occur in pairs with the intervening block downdropped. Two sets of joints are prominent, one trending northwest and the other northeast. The joint systems control the drainage pattern in the south-central part of the area.

More than 20,000 feet of sedimentary rocks underlies the area. Many of the formations yield oil or gas in northwestern Colorado, northeastern Utah, and southwestern Wyoming. The Piceance Creek gas field, in which gas occurs in the Douglas Creek member of the Green River formation, is the largest oil or gas field discovered thus far within the area.

About 7,000 million barrels of oil is contained in oil shale that yields an average of 45 gallons per ton from a continuous sequence 5 or more feet thick in the Mahogany zone. 0il shale in the Mahogany zone and adjacent beds that yields an average of 30 gallons of oil per ton from a continuous sequence 15 or more feet thick contains about 91,000 million barrels of oil. Similar shale in deeper zones in the northern part of the area, for which detailed estimates have not been prepared, are now known to contain at least an additional 72,000 million barrels of $0 i 1$. 0il shale in sequence 15 or more feet thick that yields an average of 25 gallons of oil per ton contains about 154,000 million barrels of oil in the Mahogany zone and adjacent beds; such shale in deeper zones in the northern part of the area probably contains at least an additional 157,000 million barrels of oil, although detailed estimates were not made. $0 i 1$ shale in a sequence greater than 15 feet thick that yields an average of 15 gallons of oil per ton contains more than 900,000 million barrels of oil. These estimates of the oil content of the deposit do not take into account any loss in mining or processing of the shale.

Greensmith, J. T. 1961. 0il Shales, Review of Present Economic and Geological Status. Petroleum 24(3): 87-89.

0il-shale fields are not a serious competitor of oil-pool fields, nevertheless they cover extensive areas in many countries of the world. They are a valuable asset even though commercial exploitation may be negligible at present. Recent investigations are clarifying the nature of oilshales from the geochemical, biological and mode of origin points of view. 
Dougan, P. M., F. S. Reynolds, and P. J. Root. 1960. The potential for in situ retorting of oil shale in the Piceance Creek basin of NW Colo. Colo. Sch. Mines Quart. 65(4): 57-72.

The development of alternatives to production of shale oil by the conventional mining/retorting approach has been a focus for considerable research by industry and government for a number of years. One of these, namely the production of oil from oil shale "in situ" or in place, offers many attractive features. The potential benefits to be derived from the commercialization of an in situ process are both economic and aesthetic. The most significant of these is the absence of the costly and unavoidably disfiguring mining and waste disposal functions associated with a mining/retorting operation. Other potential benefits include: lower research and development costs; lower capital cost of the intial operation; the use of conventional oil field equipment; and lower labor cost per unit of production.

Because of the potential benefits, a research program was initiated in 1961 directed toward processing oil shale in situ and producing $0 i 1$ from wells that differ little from conventional wells.

Robinson, W. E., and K. E. Stanfield. 1960. Constitution of oil-shale kerogen: bibliography and notes on Bureau of Mines research. U. S. Bur. Mines Info. Circ. 7968.

The purpose of preparing these abstracts was to assemble the important data published through 1957 about the constitution of kerogen. The study of the structure of kerogen is closely related to studies of the origin and geology of oil shale, composition and properties of the inorganic part of oil shale, and composition of shale oil. Publications of this nature contributing to the knowledge of the structure of kerogen have been included. The authors believe that these abstracts will help to correlate the available information and will be useful in future research on the constitution of kerogen.

$\underline{1959}$

Schyanberg, E. K., and A. R. L. Brandberg. 1959. Recent improvements and developing work concerning oil shale processing at Kvarntorp, Sweden. Fifth World Pet. Cong. June 1959 New York, NY Section II: 383-393.

Swedish oil shale yields comparatively little oil, and the production of Svenska Skifferoljeaktiebolaget (The Swedish Shale 0il Co.) is therefore based also on an extensive recovery of gaseous products. Consequently, only externally heated retorts are used and pyrolysis residue is used as heat source in the economically best retorting method, the BerghKvarntorp-method. The ovens of this type have recently been further 
improved by a new retort design allowing $50 \%$ increase in production. Application of the Bergh-Kvarntorp-method to foreign shales is exemplified.

Two new gas treating plants have been started. The first one is based on a new process, called the AVOX process, for catalytic removal of oxygen from the hydrogen sulfide containing pyrolysis gas resulting in a highly improved recovery of the gaseous products. The second one is a plant for steam cracking of the dry gas and synthesis of ammonia.

Research work in big bench-scale has led to a process for recovery of sulfur dioxide from flue gases by absorption in ammonium sulfite-solution.

Two methods for utilization of oil shale fines $(<5 \mathrm{~mm})$ have been investigated, viz 1) combustion, and 2) pyrolysis with subsequent gasification of the shale coke. The feasibility of the combustion has been demonstrated in large scale tests. The intended pyrolysis-gasification process uses the fluidization technique and is discussed on the basis of the big benchscale tests carried out.

The further expansion of the works of Svenska Skifferoljeaktiebolaget is dependent on a technical-exonomical solution of these two research objects.

\section{7}

Hartley, F. L., and G. A. Hemmen. 1957. 0 il shale mining and retorting methods. Mining Congr. J. 47(1): 60-62.

A discussion of an oil shale research project outlining some of the problems that are involved in pioneering the development of a vast but untouched natural resource of the United States.

1953

Sanderson, R. T. 1953. Treatment of shale. U.S. Patent 2,641,565. June 9, 1953.

1. A method for treating kerogen-type oil shales for the purpose of facilitating the separation and recovery of hydrocarbon, bituminous substances and the like associated therewith, which comproses subjecting said materials to the action of microorganisms selected from the gourp consisting of clostridium sporogenes, Clostridium histoluticisum, Clostridium lentopatrescens, Pseudomonas fluorescens and mixtures thereof, in the presence of a microbiological nutrient medium capable of supporting the metabolism of said microorganism. 
2. The method according to claim 1 in which the microbiological nutrient medium has a $\mathrm{pH}$ in the approximate range of 5.5 to 8 .

3. A method according to claim 1 in which a temperature in the approximate range of 20 to $45^{\circ} \mathrm{C}$ is maintained during the action of the microorganisms on said kerogen-type oil shales.

4. A method for treating kerogen-type oil shales for the purpose of facilitating the separation and recovery of hydrocarbon, bituminous substances and the like associated therewith, which comprises subjecting said materials to the action of microorganisms selected from the group consisting of Clostridium sporopenes, Closiridium histolyticieum, Clostridium lentopatrescens, Pscudomonas fluorescens and mixtures thereof, in the presence of a microbiological nutrient medium capable of supporting the metabolism of said microorganisms and separating resulting products from the inorganic aggregate of said material.

\section{$\underline{1952}$}

Brantley, F. E., R. J. Cox, H. W. Sohns, W. T. Barnet, and W. I. R. Murphy. 1952. High temperature shale oil. Ind. Eng. Chem. 44(11): 2641-2644.

Bench scale experiments are described in which pulverized oil shale is heated at atmospheric pressure and temperatures in the range $1200^{\circ}$ to $1800^{\circ} \mathrm{F}$. Under these conditions, the $0 i 1$ produced contains a much higher percentage of low-boiling aromatics than does the $0 i 1$ produced in conventional retorts at lower temperatures. $0 i 1$ yields for the series ranged from 47 to 59 weight \% of Fischer assay, the maximum oil yield occuring at about $1500^{\circ} \mathrm{F}$. Gas production increased rapidly with increase in temperature. The main constituent of the gases produced at temperatures up to $1700^{\circ} \mathrm{F}$. were methane, hydrogen, ethylene, and carbon dioxide, whereas the gas produced at $1800^{\circ} \mathrm{F}$. consisted almost entirely of an equimolar mixture of carbon monoxide and hydrogen. Aromatic content of the neutral naphtha fraction of the oil increased with increase in temperature and was almost $100 \%$ for the $1700^{\circ} 011$. The highest benzene yields were obtained in the temperature range $1500^{\circ}$ to $1700^{\circ} \mathrm{F}$. and amounted to as much as 5 gallons from each ton of 50-gallon-per-ton shale.

Shale oils produced by high temperature retorting at $1200^{\circ}, 1500^{\circ}$, and $1700^{\circ} \mathrm{F}$. were analyzed. These oils differ greatly in composition from those produced at ordinary retorting temperatures. Increasing the temperature of retorting increases the aromaticity of the $0 i 1$. The product at about $1500^{\circ} \mathrm{F}$. consists almost entirely of aromatic hydrocarbons and sulfur and nitrogen compounds. Furthermore, as higher retorting temperatures are used, the content of benzene and naphthalene increases until, in oil produced at about $1700^{\circ} \mathrm{F}$., they are virtually the only compounds present in the naphtha and light - gas oil ranges, respectively. 
Cady, W. E., and H. S. Seelig. 1952. Composition of shale oil. Ind. Eng. Chem. 44(11): 2636-2641.

Shale oil differs from crude petroleum in that it contains relatively large quantities of nitrogen, sulfur, and oxygen. Knowledge of its composition is essential for the production of usable petroleum products. NTU shale oil has been examined by a combination of the following techniques: distillation, extraction with a metal chloride in concentrated hydrochloric acid, adsorption, extractive crystallization with urea, and infrared spectrometry. This shale oil consists of $39 \%$ hydrocarbons and $61 \%$ compounds of nitrogen, sulfur, and oxygen. The hydrocarbons are $6 \%$ normal paraffins, $6 \%$ normal olefins, 5\% isoparaffins plus naphthenes, $12 \%$ iso-olefins plus cyclo-olefins, $4 \%$ monocyclic aromatics, and $6 \%$ polycyclic aromatics. The nonhydrocarbons are $36 \%$ nitrogen compounds, $6 \%$ sulfur compounds, and 19\% oxygen compounds. The removal or conversion of the nonhydrocarbons in shale oil to produce high-quality petroleum products will require extensive processing that is not required in conventional refining of petroleum.

Dinneen, G. U., J. S. Ball, and H. M. Thorne. 1952. Composition of crude shale oils. Ind. Eng. Chem. 44(11): 2632-2635.

At present there is no commercial oil-shale industry in the United States. Therefore, laboratory analys is and comparison of the composition of shale oils furnish information on their characteristics and on processing problems. Nineteen shale oils from seven different countries were analyzed. The shale oils not only differ as a class from petroleum but also show substantial differences in composition among themselves. The composition is influenced by both shale source and retorting conditions. The sulfur and nitrogen contents of the oil are primarily dependent on shale source. Also, when ordinary retorting methods are used, the shale source is a factor in the hydrocarbon composition of the oil. The use of high temperature retorting produces oils of greater aromaticity. Comparison of the results obtained permits characterization of the crude shale oils, evaluation of the factors affecting their composition, and determination of the relationship between American and foreign shale oils.

Larson, M. 1952. Method of extracting uranium from bituminous shales and shale culm containing uranium. U.S. Patent 2,597,504. May 20, 1952.

This invention relates to an improved method of extracting uranium from bituminous shales and shale culm containing uranium by means of a solution of alkali carbonate and consults chiefly in this that the shale or the shale culm is leached in its natural state, i.e. without a preceding coking or combustion of the raw material to ash. In such leaching operation it is not necessary to grind the raw material to a fine powder in as much as a satisfactory extraction of the uranium can be performed, if the raw material is crushed to a grain size of about 0.25 to $0.15 \mathrm{~mm}$. 
Stevens, R. F., G. U. Dinneen, and J. S. Ba11. 1952. Analysis of crude shale oi1. U.S. Bur. Mines RI 4898.

A laboratory method for examing crude shale oil is described. The method uses only about $500 \mathrm{ml}$. of sample and a limited number of analytical determinations. Results provide information on the general characteristics and composition of an $0 i 1$ and serve as a basis for comparing different oils. However, the method does not provide for direct estimates of yields of commercial products. Analyses of 10 oils produced in the United States by different methods of retorting and of 10 shale oils from commercial-scale operations in 6 foreign countries are given.

The shale-oil analysis method presented in this paper is based on and employs the same equipment as the Bureau of Mines routine method for analyzing crude petroleum. As shale oil contains groups of compounds not generally found in petroleum, several modifications of the petroleum method that might increase its suitability for application to shale oil were investigated. The modifications included in the present method take into account the apparent poor heat stability of shale $0 i 1$ and the presence of large quantities of olefins and nitrogen compounds.

Wells, W. E., and J. R. Ruark. 1952. Pilot-plant batch retorting of Colorado oil shale. U.S. Bur. Mines RI 4874.

This report describes experimental investigations made in the batchwise retorting of Colorado oil shale. Three heat-carrying mediums were used hot shale gas, super-heated steam, and hot flue gas. Using hot shale gas for retorting, the several variables studied were retort-inlet-gas temperature, gas velocity through the shale bed, shale particle size, and grade of shale. In studying the effect of any one of these variables on oil yield, gas yield and operability, the other variables were maintained essentially constant. $0 i l$ yields decreased with increasing inlet-gas temperature and increasing shale-particle size, and oil yield increased with increasing grade of shale up to 50 gallons of oil per ton of shale, beyond which process was inoperable because of swelling and coking of the shale during retorting. Changes in gas velocity had little effect on $0 i 1$ yield. Gas yield increased with increasing inlet-gas temperature, gas velocity, particle size, and shale grade. 0il yields of 100 percent of Fischer assay and from 1,600 to 1,800 cubic feet of 300-Btu gas per ton of shale were obtained.

Two runs only were made using superheated steam. $0 i 1$ yields averaged 97 percent of Fischer assay, and gas yields averaged 4,000 cubic feet per ton of shale.

Retorting with a hot flue gas produced from combustion in the shale bed, as in the $\mathrm{N}-\mathrm{T}-\mathrm{U}$ process, gave excellent yields using closely sized shale with recycling of flue gas. An excess of fine shale in the charge resulted 
in channeling and low oil yields. Using no recycle gas, good yields were obtained that tended to decrease with increasing air rate, and the

retorting rate increased with increasing air rate over the range studied. Coking was not found serious with 30 -gallon shale at the air rates used.

1951

Thorne, H. M., W. I. R. Murphy, J. S. Ball, K. E. Stanfield, and J. W. Horne. 1951. Characteristics and utilization of oil shale and shale oil. Ind. Eng. Chem. 43(1): 20-27.

This paper presents a general discussion of the properties and characteristics of $0 i 1$ shales, and shale oils, and their products, and presents briefly the results of major phases of the research and process development work now in progress at the Laramie, Wyo., station of the Bureau of Mines. For the most part, the experimental work pertains to oil shale of the Green River formation in Colorado. The properties of products obtained by retorting the oil shale and refining its shale $0 i l$ by several different processes are given. The properties of Green River oil shale and its products are also compared with those determined for several foreign oil shales.

$\underline{1950}$

Brown, D., J. M. Schmitt, F. J. Hurst, and D. J. Crouse. 1950. Recovery of uranium from oil shales. Part I. Extraction of uranium from the shale gangue. Oak Ridge Y-12 plant, Tenn. 1950, 155 pp.

The two most acceptable methods found involved either a direct acid leach of the crushed raw shale or a controlled roasting operation followed by a dilute acid leach.

Grimes, W. R., J. P. Blakely, G. R. Peterson, and G. M. Andranigian. 1950. Recovery of Uranium from oil shales Part II. Recovery of Uranium from acid leaches of shale. Oak Ridge Y-12 plant, Tenn. 1950. 101 pp.

The best of the processes studied consisted of precipitation of a uranous phosphate from soln. of low $\mathrm{pH}$ with or without added carrier material.

\section{9}

Hedval1, J. A., and S. Nordengren. 1949. Production of Potash Fertilizers from shale ash and other raw materials. Research (London) 2(12): 564-571.

Three methods: the common salt method, the iron pyrites method and the autoclave method were evaluated for the production of potash fertilizers from shale ash and raw materials. 
Berg, C. H. 0. 1948. Method and apparatus for educting oil from shale by utilizing hot spent shale. U.S. Patent 2,441,386. May 11, 1948.

An apparatus for separating oil from oil shale which comprises a shale hopper, means for commingling hot spent shale with fresh oil shale, an inclined rotary eduction retort communicating with said shale hopper, means for introducing commingled hot spent shale and hot oil shale plus steel balls into said inclined rotary eduction retort, said hot spent shale and hot steel balls being introduced in direct heat exchange with said fresh shale, means for introducing superheated eduction, steam into said inclined rotary eduction retort means for externally heating said inclined rotary eduction retort, means for educting shale oil and hydrocarbon gases from said oil shale in said inclined rotary eduction retort, means for separating said educted shale $0 i 1$ and hydrocarbon gases from carbonaceous shales in said inclined rotary eduction retort, means for removing said hydrocarbon gases from said inclined rotary eduction retort, means for removing said shale oil from said inclined rotary eduction retort, means for removing said carbonaceous shale and steel balls from said inclined rotary eduction retort, an inclined rotary roaster communicating with said inclined rotary eduction retort, means for introducing said carbonaceous shale and steel balls into said inclined rotary roaster, means for buring said carbonaceous shale in said inclined rotary roaster, means for separating flue gases from spent shale in said inclined rotary roaster, and means for removing said spent shale and steel balls from said inclined rotary roaster.

Clark, A. 1948. Fischer - Tropsch synthesis gas from oil shale. U.S. Patent 2,452,634. November 2, 1948.

This invention relates to a process for the production of hydrogen and carbon monoxide. In one embodiment it relates to the production of a mixture of hydrogen and carbon monoxide utilizing oil shale as one of the reactants. In another embodiment this invention relates to a process for the production of hydrogen and carbon monoxide for use as synthesis gas in the Fischer-Tropsch and related syntheses.

Mixtures of carbon monoxide and hydrogen are useful in synthesizing many organic compounds and a suitable mixture of these components is known to the art as "synthesis gas". Synthesis gas may be produced by the following well known reactions:

(1) $3 \mathrm{CH}_{4}+\mathrm{CO}_{2}+2 \mathrm{H}_{2} \mathrm{O} \rightarrow 4 \mathrm{CO}+8 \mathrm{H}_{2}$

(2) $\mathrm{CH}_{4}+\mathrm{CO}_{2} \rightarrow 2 \mathrm{CO}+2 \mathrm{H}_{2}$

(3) $\mathrm{CH}_{4}+\mathrm{H}_{2} \mathrm{O} \rightarrow \mathrm{CO}+3 \mathrm{H}_{2}$ 
I have discovered a method of producing synthesis gas by partial combustion of oil shale and in utilizing the resulting hot spent shale as a heat exchange medium to bring the temperature of a mixture of hydrocarbon gas, carbon dioxide and/or steam up to a point where synthesis gas is produced.

Reed, H., and C. Berg. 1948. Shale and air counter-flow in a new continuous retort. Pet. Proc. 3(12): 1187-1192.

In its shale oil research program Union $0 i 1$ Co. of California has developed a new type of continuous retort which, because of a unique method of counter-flow of shale and air, eliminates the need for large quantities of cooling water and heat exchangers, thus reducing capital and operating costs. A 50-ton/day semi-conmercial unit is now being operated and it is expected commercial units will reach a capacity of 4000 tons/day of shale. $0 i 1$ recoveries exceed assay values, and large quantities of fuel gas produced in the retorting operation are a potential resource of power at the retorting and mining site.

\section{7}

Barr, F. T. 1947. Distillation of oil shale in fluidized condition with simultaneous combustion of spent shale. U.S. Patent 2,432,135. Dec. 9, 1947.

A continuous process for recovering oil from shale which comprises continuously charging finely divided oil shale into a steam initially comprising an oxygen-containing gas and substantially fluidizing the oil shale in said stream, passing the stream of thus fluidized shale upwardly continuously into a reactor, maintaining the fluidized shale in said reactor in a fluidized state for a period, meanwhile promoting sufficient combustion of combustible matter in the fluidized shale in said reactor to maintain a temperature therein of about $800^{\circ} \mathrm{F}$. to about $1000^{\circ} \mathrm{F}$., thereby causing the formation of gas and condensable volatile matter from said oil shale, continuously removing the said stream along with the oil shale reaction products overhead and separately recovering therefrom condensable hydrocarbons, and withdrawing the spent shale from the lower portion of the mass of oil shale fluidized in said reactor.

\section{7}

Woolnough, W. G. 1937. Sedimentation in borred basins and source rocks of 0i1. An Assoc. Pet. Geol. Bul1. 21(9): 1101-1157.

While the DOCTRINE OF UNIFORMITY must always form the basis of geological theory, it is necessary to admit that phenomena have occurred during geological time which have not been observed at all, or not in their entirety, during the very limited period of modern scientific investigation. 
Reasons are given for the belief that major coal measures, major primary salt deposits, major fresh-water series of sediments, and source rocks of $0 i 1$ deposits are not now being deposited anywhere on the earth.

No continent-wide peneplanation of advance maturity, comparable, for example, with the Middle Tertiary peneplanation of Australia, can be recognized at the present day. It is believed that the present is largely a period of orogeny rather than of peneplanation.

It seems probable that periods of greatly enhanced humidity and of greatly enhanced aridity, and others of wide temperature fluctuations have marked many eras in the geological past, and have left their impress on sediments formed during such eras. The present condition of the earth can not be assumed to be the only "normal" one in earth history. In cases where the characteristics of geological formations require explanations other than those afforded by the strict application of the Doctrine of Uniformity it is legitimate and necessary to invoke causes not now observed in operation, provided always that objective evidence, not conformable with conventional explanations, can be adduced.

The close relationship between sediments and their environment has been emphasized by Twenhofel, and the fossil contents of such sediments generally but not always conform with this environment. The grade of this relationship under different circumstances is discussed in some detail.

It is insisted that under normal conditions of deposition in any environment there should be preserved a BALANCED ASSEMBLAGE of fossil forms, including benthos, nekton, and plankton in suitable proportions. Any unbalance of assemblage indicates something abnormal in conditions of deposition, and demands explanation.

The main thesis of this paper is an amplification of the "Bar Theory" of 0chsenius. It is suggested that, when all implications of this theory are considered, the possiblity is indicated of existence in the geological past of "barred basins" of dimensions and characters entirely unrepresented at the present day.

Reasons are given for associating barred basins chiefly with maturity of peneplanation. Climatic factors are considered and it is concluded that humidity favors development of lacustrine conditions, of coal, boghead, and oil shale; while aridity controls formation of black shales, source rocks of oil, and ultimately salt deposits. Certain characteristics are common to all such deposits. 
-

-

$-$ 
INDEXES 
WORD INDEX

Abstracts

Anon; 1976a

Hundemann, A. S.; 1976

Stanford Staff; 1976

Johnson, H. R.; 1975

Air Pollution, 0il Shale Processing

Kirkpatrick, L. W.; 1974

Hughes, E. E.; 1975

Nielsen, I.; 1973

Alumina, Recovery

Haas, F. C.; 1975

$\underline{\text { Analytical Techniques }}$

Beck, B. L.; 1971

Stevens, R. F., et a 1; 1952

Tyler, A. L.; 1974

Siggia, S., et a1.; 1974

Smith, J. W., et a1.; 1974, 1967

Riley; 1976

Scrima, D. A., et a1.; 1974

Johnson, D. R., et a1.; 1970

Miknis, F. P.; 1974a, b

Poulson, R. E., et al.; 1971

Reed, P. R., et a1.; 1974

Anvil Points

Callahan, J. M.; 1974

Pforzheimer, H.; 1974

Zambas, P. G., et a1.; 1972

Beck, B. L.; 1971

Donnel1, J. R.; 1961

Aragonite

Smith, J. W., et al.; 1973

\section{Bergh-Kvarntorp}

Schyanberg, E. K., et a1.; 1959

Bibliographies

Stanford Staff; 1976

Sylvester, R. D.; 1975

Anon; 1976a

Hundemann, A. S.; 1976

Rogers, M. P.; 1974

Bioleaching

Meyer, W. C.; 1974

Young, D. K., et a1.; 1974

Biotite

Livering, T. G.; 1969

Bitumen

Scrima, D. A., et a1.; 1974

Anders, D. E., et al.; 1973

Robinson, W. E.; 1969

Cummins, J. J., et a1.; 1964

Ferris, B. J.; 1948

Bituminous Shale

Larson, M.; 1952

Black Water (Trona Water)

Dana, G. F., et a1.; 1973

Foster, J. I., et al., 1972

Bureau of Mines

Chambers, P. S.; 1970 
Carbon Oxidation

Tyler, A.L.; 1974

Carcinogenicity

Berenblum, I., et a 1.; 1944

Vysamyae, A. I.; 1975

Catalysts

Bureau of Land Management Staff, 1975 Heley, W.; 1974

Marsha11, P. W.; 1974

Hughes, E. E., et a1.; 1975

Characterization, 0 il Shale

Jensen, H. B., et al.; 1971

Dinneen, G. U., et a1.; 1952

Cady, W. E., et a1.; 1952

Haines, W. E., et al.; 1967

Bozak, R. E.; 1976

Thorne, H. M., et a 1.; 1951

Smith, J. W.; 1968

Schmidt-Collerus; 1974

Poulsen, R. E., et a 1.; 1974

Hanson, R. L., et al.; 1975

Cook, G. L., et a1.; 1968

Dancy, T. E., et a1.; 1950

Bozak, R. E.; 1976

Chroma tography

Poulson, R. E.; 1969

Snyder, L. R., et a 1.; 1968

Brown, D., et a1.; 1970

Coal

Rammler, R. W.; 1970

Coal and Shale, Chemicals from

Sherwin, M. B., et a 1.; 1975

Coke

Bonomo, F.; 1974

Anon; 1972a
Commerce Technical Advisory Board Staff

Subcommittee on Energy; 1974

Linden, H. R.; 1974

Hughes, E. E., et a1.; 1974

Anon; 1972b

Anon; 1975

Globe, S., et a1.; 1975

Colony Development Operation
Marshail, P. W.; 1975

Anon; 1965

Anon; 1975a

Crookston, R. B.; 1975

Colony Development Operation Staff;

$1975 a, b, c, d$

Colony Suspension

Anon; 1975a

Crookston, R. B.; 1975

Colorado

Rold, J. W.; 1974

Cashion, W. B. ; 1967

Ert1, T.; 1965

Anon; 1964

Donne11, J. R.; 1961

Cook, E. W.; 1974

Fischer, R. C.; 1974

Nielsen, I.; 1973

Howe, C. W., et a 1.; 1972

Zambas, P. G., et a1.; 1972

Control Blasting

Livingston, C. W. ; 1973

Coprope 1

Bradley, W. H.; 1966 
Disulfurization and Denitrogenation

Satterfield, C. N., et a1.; 1975

Douglas Creek Member

Donnel1, J. R.; 1961

Economics

Novak, A.; 1976

Lekas, M. A.; 1966

Howe, C. W. , et a1.; 1972

Kate11, S., et a1.; 1974

Electrocarbonization

Sarapuu, E.; 1965

Energy Alternatives

Oklahoma Univ. Staff; 1975

Petzrick, P. A.; 1975

Zitting, R. T.; 1975

Subcommittee on Energy; 1974

Energy Development

Bowden, C.; 1975

\section{Energy Situation}

Glenn, W. E.; 1974

Meyer, J. W., et a1.; 1974

Linden, H. R.; 1974

Environmental Impacts

Radian Corp. Staff; 1975

Hughes, E. E.; 1974

Dickson, E. M.; 1974

Schmidt, R. A.; 1974

Piku1, R. P.; 1974

Anon; 1974

Anon; 1975
Battelle, Pacific Northwest Laboratories Staff; 1975

Bonomo, F.; 1974

Bowden, C.; 1975

Bureau of Land Management Staff; 1975

Burke, H. D.; 1975

Cameron, R. J.; 1974

Conkle, N., et a1.; 1974

Decora, A. W. ; 1974, 1975

Dept. of Interior Staff; 1973a, b, c, $d, e, f$

Doyle, W. S.; 1975

Everhert, W. H., et a1.; 1973

Fletcher, K. H., et a1.; 1973

Hand, J. W.; 1969

Howe, C. W., et a1.; 1972

Hundemann, A. S.; 1976

Hutchins, J. S., et a1.; 1971

Kilburn, P. D.; 1976, 1974

Kirkpatrick, L. W.; 1974

Mock, H. B.; 1968

Persse, F. H.; 1975

Russe11, P. L.; 1974

Spence, H. M.; 1974

Stone, R. T., et a1.; 1974a, 1974b

Ward, J. C., et a1.; 1971a, 1971b, 1972 , et a 1 .

Wyoming Water Resources Research Inst. Staff; 1975

\section{Evacuation Creek}

Donnel1, J. R.; 1961

\section{Fischer Assay}

Goodfellow, L., et a1 .; 1974

Cummins, J. J., et a1.; 1972

Beck, B. L.; 1971

Bae, J. H.; 1969

Wells, W. E., et a1.; 1952

Clark, A.; 1948

Reed, P. R., et a1.; 1974

Hubbard, A. B.; 1965

Fossil Fuels

Magee, E. M., et a1.; 1973 
Fossil Porphyrins

Blumer, M., et a1.;1970

Fracturing

Miller, J. S., et a1.; 1974

Campbe11, G. G., et al.; 1970

Melton, N. M., et a1.; 1970

Lekas, M. A., et al.; 1965

Garden Gulch Member

Donnel1, J. R.; 1961

Garfield County

Kirkpatrick, L. W.; 1974

Garrett Process

Ridley, R. D., et al.; 1975

Gas Combustion Retort Process

Guthrie, B.; 1964

Ruark, J.R., et a 1; 1971

Green River Formation

Young, N. B., et al.; 1975

Cummins, J. J., et a $1 . ; 1974$

Geol. Society of America Staff; 1974

Trude11, L. G., et a1.; 1974

Anders, D. E., et al; 1973

Pitman, J. K., et a1.; 1973

Smith, J.W., et a1.; 1973

Cummins, J.J., et a1.; 1972

Dana, G. F., et al.; 1972

Smith, J. W., et a1.; 1972

Donnel1, J. R., et al.; 1972

Cashion, W. B.; 1967

Dinneen, G. U., et al.; 1968

Bradley, W. H.; 1966

Sohns, H. W., et a1.; 1966
Jaffe, F. C.; 1962

Schmidt-Collerus, J. J., et a1.; 1974

Yen, T. F.; 1976

Jackson, L. P., et a1.; 1975

Robinson, W. E., et al.; 1975

Kate11, S., et a1.; 1974

Meyer, W. C.; 1974

Pfeffer, F. M., et al.; 1974

Reed, P. R., et a1.; 1974

Schmidt-Collerus, J. J.; 1974

Scrima, D. A., et a1.; 1974

Sladek, T. A.; 1974

Anders, D. E., et a1.; 1973

Cook, E. W.; 1973

Dana, G. F., et a1.; 1974

Science Policy Research Division

Staff-Library of Congress; 1973

Foster, J. I., et a1.; 1972

Steel, G., et al.; 1972

Gelpi, E., et al.; 1971

Henderson, W., et a1.; 1971

Robinson, W. E., et a1.; 1971

Cook, G. L., et al.; 1968

Smith, J.W.; 1968

Smith, J. W., et al.; 1964

Ferris, B. J.; 1948

History

Carlton, K.; 1975

Hydration, Illite

Routson, R. C., et a1.; 1972

Chenevert, M. E.; 1970

Hydrocarbons

Schora, F. C., et a1.; 1974

Williamson, D. R.; 1964

Bendoraitis, J. G., et a1.; 1962

Grimmer, G., et al.; 1975

Kimble, B. J., et a1.; 1974

Anders, D. E., et al.; 1973

Cummins, J. J., et a 1.; 1964 
Hydrocarbon Types

Jackson, L. P., et a1.; 1974

Jacobson, I. A., et a1.; 1974

Hydrocracking

Cottingham, P. L., et a1.; 1975

Cottingham, P. L., et a1.; 1973

Brown, D., et a1.; 1970

Frost, C. M. , et a1.; 1974

Frost, C. M., et a1.; 1973

Hydrodenitrification

Frost, C. M., et a1.; 1973

Hydrogasification

Schora, F. C., et a1.; 1974a, 1974b

Hydrogeneration

Schora, F. C., et a1.; 1974

Hydrogen Production

Holm, M. M.; 1971

\section{Hydrotorting}

Schlinger, W. G., et al.; 1967

Schlinger, W. G., et al.; 1968

Ichthyol

Blade, 0. C.; 1938

In Situ

Decora, A. W.; 1975

Johnson, W. F., et a 1.; 1975

Ridley, R. D., et a1.; 1975

Miller, J. S., et al.; 1974

Ridley, R. D.; 1974
Burwe11, E. L.; 1973a

Smith, J. W., et a1.; 1972

Jensen, H. B., et a1.; 1971

Barnes, A. L., et a 1.; 1968

Lekas, M. A.; 1966

Sohns, H. W., et a1.; 1968

Borg, I.; 1973

Hi11, G. R., et a1.; 1967

Dougan, P. M., et a1.; 1960

Lewis, A. E.; 1975

Jackson, L. P., et a 1.; 1975

Morandi, J. R., et a1.; 1975

Penner, S. S.; 1975

Rothman, A. J.; 1975

Snyder, P. W., et a1.; 1975

Carpenter, H. C., et al.; 1974

McDonald, F. R.; 1974

Pfeffer, F. M., et a1.; 1974

Poulson, R. E., et al.; 1974

Burwe11, E. L., et a1.; 1974

Barnes, A. L., et al.; 1968

Carpenter, H. C., et a 1.; 1968a, 1968b

Burwe11, E. L.; 1973b

Campbe11, G. G., et a1.; 1970a, 1970b

Carpenter, H. C., et al.; 1974

Dougan, P. M., et a1.; 1960

Grant, B. F.; 1964

Jensen, H. B., et a1.; 1971

Johnson, W. F., et a1.; 1975

Miller, J. S., et a1.; 1974

Penner, S. S.; 1975

Ridley, R. D., et al.; 1974, 1975

Rothman, A. J.; 1975

Sarapuu, E.; 1965

Snyder, P. W., et a1.; 1975

Isoprenoid Hydrocarbons

Bendoraitis, J. G., et al.; 1962

Cummins, J.J., et a1.; 1964

\section{Kerogen}

Vandenberg, M. L. J.; 1975

Williamson, D. R.; 1974

Cummins, J. J., et al.; 1972

Robinson, W. E., et a1.; 1972, 1973, 1975

Robinson, W. E., et a1.; 1960, 1969, 1971 
Kerogen Conversion

Duva11, J. J., et a1.; 1974

Gallegos, E. J.; 1975

Leythaeuser, D.; 1973

Laramie Energy Research Center

Anon, 1975

Carpenter, H. C., et al.; 1974

Thorne, H. M., et al.; 1951

Laser Pyrolysis

Hanson, R. L., et a1.; 1975

Leases 0 il Shale

Dept. of Interior Staff; 1973a, 1973b, 1973c, 1973d, 1973e, 1973f Kalter, R. J., et al.; 1975

Low Sulphur Fuels

Smith, R. H.; 1973

Low Temperature Ashing

Smith, J.W., et a1.; 1974

\section{Lurgi-Ruhrgas Process}

Rammler, R. W.; 1969, 1970a, 1970b

Mahogany Zone

Pitman, J.K., et al.; 1973

Smith, J.W., et a1.; 1973

Smith, J.W., et al.; 1972

Cashion, W. B.; 1967

Ert1, T.; 1965

Meyer, W. C.; 1974

Pitman, J.K., et al.; 1973
Messel 0il Shale

Kimble, B. J., et a1.; 1974

Methylindole

Jacobson, I. A.; 1971

Mine Drainage Problems

Coffin, D. L., et al.; 1973

Mining

Herkenhoff, E. C.; 1972

Callahan, J. M.; 1974

Crookston, R. B.; 1975

Persse, F. H.; 1975

Leach, H. J.; 1975

Livingston, C. W. ; 1974

Marsha11, P. W.; 1974, 1975

Smith, J. W., et a1.; 1969

Ert1, T.; 1965

Hartley, F. L., et a1.; 1957

Katel1, S., et a1.; 1971

Molybdenum

Voegeli, P. T., et al.; 1969

Naphtha

Barker, L. K., et a 1.; 1973, 1972

$\underline{\text { Natural Fuels }}$

Smith, J.W., et al.; 1967

National Environmental Policy Act-NEPA

Rutledge, P. A.; 1975 
Nitrogen Compounds, $0 i 1$ Shale

Snyder, L. R., et a 1.; 1968

Mapstone, G. E., et al.; 1950, 1948

Poulson, R. E., et a1.; 1971

Morandi, J. R., et a1.; 1975

Dinneen, G. U., et a 1.; 1958

Frost, C. M.; 1973, 1974

Haines, W. E., et a1.; 1967

Mapstone, G. E., et a 1.; 1948a, 1948b, 1948c, 1948d, 1948e, $1948 f, 1948 \mathrm{~g}, 1950$

Morandi, J.R., et a 1.; 1975

Poulson, R. E., et a1.; 1969, 1971, 1975,1977

\section{Nuclear Fracturing}

Williams, F. E., et a1.; 1969

Lekas, M. A., et a 1.; 1965, 1976

Coffer, H. F., et al.; 1966

Sweeton, F. H., et a 1.; 1975

Wethington, J. A. Jr.; 1972

Williams, F. E., et a1.; 1969

$\underline{0 i 1}$

Berg, C.; 1948

\section{0 il Recovery}

Herre11, A. Y.; 1975

\section{0il Shale}

Stanford Research Inst. Staff; 1976

Clark, C. E., et a1.; 1975

Eliason, M. D.; 1975

Miller, P. B.; 1975

Glenn, W. E.; 1974

Gilmore, J. S., et a1.; 1974

Geol. Soc. of Amer. Staff; 1974

Kirkpatrick, L. W.; 1974

Livingston, C. W.; 1974

Ridley, R. D., et al.; 1974

Smith, J. W.; 1974

Williamson, D. R.; 1974

Anon; 1972

Kate11, S., et a 1; 1972
McDermott, J.; 1972

Zambas, P. G., et a1.; 1972

Beck, B. L.; 1971

Kate11, S., et a1.; 1971

Cook, E. W.; 1970

Rammler, R.; 1970a, 1970b

Dayton, S. H., et al.; 1969

Dinneen, G. U., et a1.; 1968

Williamson, D. R.; 1964

Borg, I. ; 1973

Jaffe, F. C.; 1962

Williamson, D. R.; 1964

Donne11, J. R.; 1961

Hartley, F. L., et a1.; 1957

Thorne, H. M., et a1.; 1951

Grimes, W. R., et a1.; 1950

Bozak, R. E.; 1976

Yen, T. F.; 1976

Battelle, Pacific Northwest Laboratories Staff; 1975

Anon; 1975

Burke, H. D.; 1975

DiSante, E.; 1975

Johnson, H. R.; 1975

Ligon, D. R.; 1975

Petzrick, P. A.; 1975

Sladek, T. A.; 1975

Anon; 1974

Burwel1, E. L., et a1.; 1974

Hendricks, D. W., et a 1.; 1974

Livingston, C. W.; 1974

Metz, W. D.; 1974

Pfeffer, F.M., et a1.; 1974

Piper, W. M.; 1974

Reed, P. R., Jr., et a1.; 1974

Rogers, M. P.; 1974

Schmidt-Collerus, J. J.; 1974

Siggia, S., et al.; 1974

Sladek, T. A.; 1974

Smith, C. D.; 1974

Sparks, F. L.; 1974

Subcommittee on Energy, U.S. House of Representatives; 1974

Schmeh1, W. R., et a 1.; 1973

Science Policy Research Div Staff, Library of Congress; 1973

Cook, G. L.; 1972

Zambas, P. G., et a $1 . ; 1972$

Hand, J. W. ; 1969

Carpenter, H. C., et a1.; 1968

Rube1, A. C.; 1954

Mapstone, G. E., et a1.; 1952

Mapstone, G. E.; 1950

Dancy, T. E., et a 1.; 1950

Ferris, B. J.; 1948 


\section{Oil Shales Status}

Anon; 1964, 1972, 1975d

Smith, J.W.; 1972, 1964

Decora, A. W.; 1974

Dinneen, G. U. et a1.; 1968

Anon; $1975 f$

Atwood, M. T.; 1973

Cook, E. W. ; 1974

Cook, G. L.; 1972

DiSante, E.; 1975

Eliason, M. D.; 1975

Geol. Survey of America Staff; 1974

Gilmore, J. S., et al.; 1974

Glenn, W. E.; 1974

Herkenhoff, E. C.; 1972

Johnson, H. R.; 1975

Katel1, S., et a1.; 1972, 1974

Lewis, A. E.; 1975

Ligon, D. R.; 1975

Metz, W. D.; 1974

Miller, P. G.; 1975

Novak, A.; 1976

Perrini, E. M.; 1975

Petzrick, P. A.; 1975

Piper, E. M.; 1974

Rubel, A. C.; 1954

Rutledge, P. A.; 1975

Schyanberg, E. K., et a1.; 1959

0il Yields

Smith, J. W.; 1972, 1964

Cashion, W. B.; 1967

Dana, G. F., et al.; 1972

Origin, 0il Shale

Bradley, W. H. ; 1966

Woolnough, W. G.; 1937

0il Shale Development

Rold, J. W.; 1974

Chambers, P. S.; 1970

Kilburn, P. D.; 1976

Conke1, N.; 1974

Cook, E. W.; 1974b

Stone, R. T., et al.; 1974

\section{Oil (Spent) Shale Leaching}

Yen, T. F.; 1976

Young, D. K., et al.; 1974

Oil Shale Particle Size

Moussavi, M.; 1974

0il Shale Process Wastes

Routson, R. C.; 1976a, 1976b, 1976c

Routson, R. C.; 1975

Oil Shale Retorts

Williamson, D. R.; 1974

Burwe11, E. L.; 1973

Ellington, R. T.; 1973

Barney, J.H., et a1.; 1972

Barnes, A. L., et al.; 1968

Williamson, D. R.; 1964

Oil Shale Symposium

Anon; 1964

Gary, J. H. ; 1975

Giltner, R. E., et a1.; 1974

Oil Shale Technology

Dinneen, G. U., et a1.; 1968

Cook, E. W. ; 1974

Parachute Creek

Colony Development Operation Staff; 1974

Donne11, J. R., et a1.; 1970, 1961

Paraho

Kunchal, K. S.; 1975

Pforzheimer, H.; 1974

Anon; 1975 
Persian Gulf

Cooley, F. G.; 1974

Petrosix

Anon; 1976

Piceance Creek Basin

Kirkpatrick, L. W.; 1974

Smith, J. W.; 1974

Trude11, L. G., et a 1.; 1974

Anders, D. E., et a $1 . ; 1973$

Pitman, J. K.; 1973

Donne11, J. R., et a 1.; 1970

Cashion, W. B.; 1967

Smith, J. W., et a1.; 1967

Lekas, M. A. ; 1966

Borg, I.; 1973

Hi11, G. R., et a1.; 1967

Donnel1, J. R.; 1961

Dougan, P. M.; 1960

Robinson, $W$. E., et a 1.; 1975

Everhert, W. H., et a1.; 1973

Pitman, J. K., et a1.; 1973

Plants

Baker, J. M.; 1970

Potash Fertilizers

Hedva11, J. A., et a 1.; 1949

Pollution, Water

Pfeffer, F. M., et a1.; 1974

Polycyclic Aromatic Hydrocarbons

Grimmer, G., et a1.; 1975

Schmidt-Collerus; 1974a, 1974b
Prerefining

Silver, H. F., et a1.; 1972, 1974

Satterfield, C. N., et a1.; 1975

Schora, F. C., Jr., et a1.; 1974a, 1974b

Cottingham, P. L., et a1.; 1975

Klass, D. L.; 1975

\section{Production Composition}

Dinneen, G. U., et a1.; 1952

Project Independence

Commerce Technical Advisory Board Staff; 1975

Globe, S., et a1.; 1975

Petzrick, P. A.; 1975

Publications, Bureau of Mines

Sylvester, R. D.; 1975

Public Land Law Review

Mock, H. B.; 1968

Pyrolysis

Arnold, C., Jr.; 1975

Jacobson, I. A., Jr., et a 1.; 1974

Sarapuu, E.; 1965

Gallegos, E. J.; 1975

Carlson, F. B., et al.; 1974

Gallegos, E. J.; 1974

Schmidt-Collerus, J. J.; 1974

Cummins, J. J.; 1964

Montgomery, D. P.; 1968

Regulations

Rutledge, P. A.; 1975 


\section{Reserves}

Novak, A.; 1976

Retorting

Doggett, J. N.; 1975

Fausett, D. W. ; 1975

Frost, C. M., et a 1.; 1974

Jacobson, I. A., Jin., et a 1.; 1974

Grant, B. F.; 1964

Rammler, R.; 1970a, 1970b

Bae, J. H.; 1969

Lekas, M. A.; 1966

Lekas, M. A., et a1.; 1965

Williamson, D. R.; 1964

Borg, I. ; 1973

Hartley, F. L., et a 1.; 1957

Schmidt-Collerus, J. J.; 1974a, 1974b

Bonomo, F.; 1974

Snyder, P. W., Jr., et a1.; 1975

Burwe11, E. L., et a1.; 1974

Barnes, A. L., et a 1.; 1968

Ellington, R. T.; 1973

Poulson, R. E., et al.; 1974

Ruark, J. R., et a1.; 1971

Carpenter, H. C., et a 1.; 1968

Barney, J.H., et a 1.; 1972

Barr, F. T.; 1947

Callahan, J. M.; 1974

Doggett, J. N. ; 1975

Duva11, J. J., et a 1.; 1974

Guthrie, B.; 1964

Hendrickson, T. A.; 1974a, 1974b

Reed, H.; 1948

Sanderson, R. T.; 1953

We11s, W. E., et a1.; 1952

Zambas, P. G., et al.; 1972

\section{Revegetation}

Cook, E. W.; 1974b

Donovan, R. P., et al.; 1976

Kilker, C.; 1975

Williamson, D. R.; 1964a, 1964b
Reviews, 0il Shale

Sladek, T. A.; 1974, 1975a, 1975b

Conkle, N., et a1.; 1974

Greensmith, J. T.; 1961

Jaffe, F. C.; 1962a, 1962b

Rubel, A. C.; 1954

Rifle

Pforzheimer, H.; 1974

Zambas, P. G., et a 1.; 1972

Beck, B. L.; 1971

Rio Blanco Event

Kirkpatrick, L.W.; 1974

Rock Springs

Frost, C. M., et a1.; 1974

Miller, J. S., et al.; 1974

Campbe11, G. G., et a1.; 1970

Melton, N. M., et al.; 1967

Science Policy Research Staff

Yen, T.; 1976

Sedimentation

Woolnough, W. G.; 1937

Shale

Sanderson, R. T.; 1953

Reed, H., et al.; 1948

Carlton, K.; 1975

Bloch, M. B., et al.; 1973

Leythaeuser, D.; 1973

Berenblum, I., et a 1.; 1944 
Shale Alteration

Chenevert, M. E.; 1970

Shale Ash

Hedvall, J. A., et a1.; 1949

Berg, C.; 1948

Shale and Tar Sands

Perrini, E. M. ; 1975

Shale Gasification

Schora, F. C., Jr., et a1.; 1974

Shale 0il

Callahan, J. M.; 1974

Frost, C. M., et al.; 1974

Hendrickson, T. A.; 1974

Atwood, M. T.; 1973

Schramm, L. W.; 1970

Hi11, G. R., et al.; 1967

Brantley, F. E., et al.; 1952

Cady, W. E., et a1.; 1952

Dinneen, G. U., et al.; 1952

Stevens, R. F., et al.; 1952

Wells, W. E., et al.; 1952

Rogers, M. P.; 1974

Thorne, H. M., et al.; 1951

Lewis, A. E.; 1975

Silver, H. F., et al .; 1974

Hendrickson, T. A.; 1974

Jackson, L. P., et al .; 1974

Kate11, S., et a1.; 1974

Kilburn, P. D.; 1974

Siggia, S., et al.; 1974

Pitman, J. K., et al.; 1973

Poulson, R. E., et al.; 1972, 1971

Haines, W. E., et al.; 1967

Berenblum, I., et a1.; 1944
Shale 0il Gas

Silver, H. F., et al.; 1972

Dinneen, G. U., et al.; 1958

Sodium-Calcium Carbonate

Smith, J. W.; 1971

Shale 0il Naphtha

Barker, L. K., et a1.; 1973

Synthetic Natural Gas

Barker, L. K.; 1975

Schora, F. C., Jr., et a1.; 1974

Linden, H. R.; 1968

Solid Fuels

Zitting, R. T.; 1975

Spectrographic Method

Lovering, T. G.; 1969

Strip Mining

Persse, F. H.; 1975

Stratiography, 0il Shale

Trude11, L. G., et a1.; 1974

Spent Shale

Berg, C.; 1948

Hedva11, J. A., et a 1.; 1949

Culbertson, W. J., Jr., et al.; 1970

Hand, J. W.; 1969

Heley, W.; 1974

Nevens, T. D., et a1.; 1970 
Sulphur Recovery

Yen, T. F. (Ed.); 1976

Superior Process

Weichmann, B.; 1974

Paxton, J.; 1975

Sweetwater County

Wyoming Water Resources Research Inst. Staff; 1975

Smith, J.W.; 1968

Synthetic Crude

Frost, C. M., et a 1.; 1974

Klass, D. L.; 1975

Rammler, R.; 1970a, 1970b

Synthetic Fuels

Cameron, R. J., et al.; 1970

Linden, H. R.; 1968

Sulphur Compounds

Kinney, I. W., Jr., et al.; 1952

Mapstone, G. E., et al.; 1952

Poulson, R. E., et al.; 1975

Smith, J. W.; 1964

Tar Sands

Radian Corp. Staff; 1975

McDermott, J.; 1972

Rammler, R.; 1970

Thermal Analysis

Cook, E. W. ; 1970

Johnson, D. R., et a1.; 1970

Smith, J.W., et al.; 1967
Thermal Reactions

Jackson, L. P., et a 1.; 1975

Jacobson, I. A., Jr.; 1971

Cummins, J. J., et a 1.; 1974, 1972

Brantley, F. E., et al.; 1952

Cook, E. W.; 1970

Thiophenes

Kinney, I. W., Jr., et al.; 1952

Torbanite

Mapstone, G. E., et a1.; 1952

$\underline{\text { Toscoal }}$

Carlson, F. B., et al.; 1974

Tosco II

Hendrickson, T. A.; 1974

Heley, W.; 1974

Hughes, E. E., et a1.; 1975

Kilburn, P. D.; 1974

Bloch, M. B., et al.; 1973

Trace Elements

Cook, E. W.; 1973

Lovering, T. G.; 1969

Tritium Decontamination

Arnold, W. D.; 1970

Sweeton, F. W.; 1975

Wethington, J. A., Jr.; 1972

Trona Acids

Foster, J. I., et al.; 1972 


\section{Tropical Lakes}

Bradley, W. H.; 1966

Uinta Basin

Smith, J. W., et al.; 1972

Cashion, W. B.; 1967

Robinson, W. E., et a1.; 1975

Underground Mining Systems

Hoskins, W. N., et a1.; 1975

Uranium

Larson, M. ; 1952

Brown, D., et al.; 1950

Grimes, W. R., et a1.; 1950

Cottingham, P. L, et a $1 . ; 1973$

Valerolcatone

McDonald, F. R.; 1974

Water Waste

Hubbard, A. B.; 1971

Wastes, Coal

Coalgate, J. L.; 1975

Magee, E. M.; 1973

Water Pollution

Ward, J. C., et a1.; 1971

Ward, J. C., et a1.; 1972

Ely, N.; 1968
Water Problems

Ely, N.; 1968, 1967

Cooley, F. G.; 1974

01iver, W. B.; 1973

Fischer, R. C.; 1974

Sparks, F. L.; 1974

White River

Donnel1, J. R.; 1961

Cooley, F. G.; 1974

Wildlife

Burke, H. D.; 1975

Wastes, 0il Shale

Hand, J. W. ; 1969

Magee, E. M., et a 1.; 1973

Water Pollution Potential, 0il Shale

Ward, J. C., et a1.; 1971, 1972

Dana, G. F., et a1.; 1972

Yields, 0il Shale

Cook, E. W.; 1974

Smith, J. W.; 1964

Cashion, W. B.; 1967 
i.

$\checkmark$ 


\section{AUTHOR INDEX}

Albernathy, F. H., 55

Albrecht, P., 49

Allbright, C. S., 48

Anders, D. E., 60, 122

Andranigian, G. M. , 150

Appleman, M. D. , 27

Arnold, C., Jr. 97, 101

Arnold, W. D., 77

Arpino, P., 49

Atwood, M. T., 45,47,56, 108, 113,122

Bae, J. H., 79, 132

Bailey, C. W., 88

Baker, J. M., 78

Baldwin, M. F., 63

Ba11, J. S., $89,148,149,150$

Barga, G. M., Jr., 64

Barker, L. K., 98,122,123

Barnes, A. L., 133

Barnet, W. T., 147

Barney, J. H., 125

Barr, F. T., 152

Barton, C. J., 106

Battelle, Pacific Northwest Laboratory Staff, 28

Beard, T. N., 120

Beck, B. L., 128

Bendoraitis, J. G., 142

Berenblum, I., 93

Berg, C., 151,152

Berg, W. A., 60

Bilis, J. B., 33

Blade, 0. C., 94

Blair, R. W., Jr., 131

Blakely, J. P., 150

Bloch, M. B., 60

Blumer, M., 78

Böhnke, H., 32

Bonomo, F., 26, 43, 54,56

Borg, I., 123

Bowden, C., 28

Bozak, R. E., 23

Brackebusch, F. W., 73,127.

Bradley, W. H., 137

Brandberg, A. R. L., 145

Brantley, F. E., 147

Braun, R. L., 98

Bredehoeft, J. D., 61

Breger, I. A., 55

Brown, B. L., 142

Brown, D. , 150

Brown, K. B., 79
Buder, P. A., 33

Buel1, B. E., 84

Bunger, J. W., 96

Bureau of Land Management Staff, 98

Burger, E. D., 29

Burke, H. D., 29

Burlingame, A. L., 74

Burwe1 1, E. L., 44,61, 108, 123

Cady, W. E., 148

Callahan, J. M., 108

Cameron, R. J., 45,130

Campbe11, G. G., 130

Carlson, F. B., 45,108

Carlton, K., 29

Carpenter, H. C., $45,47,61,76,82,138$, 139

Carthew, D., 132

Carver, H. E., 140

Cashion, W. B., 135

Chambers, P. S., 130

Chenevert, M. E., 130

Clark, A., 151

Clark, C. E., 99

Clugston, D. M., 96

Coalgate, J. L., 99

Cocchetto, J.F., 41

Coffer, H. F., 86

Coffin, D. L., 61

Colony Development Operation

Staff, 109, 110

Commerce Technical Advisory

Board Staff, 29

Cook, E. W. , 46,61, 131

Cook, G. L., $26,40,52,66,69,75,76$, $82,85,88,111,115,129,134$

Cooley, F. G., 46

Conkle, N., 45

Cotsworth, P. F., 96

Cottingham, P. L., 56,99, 111, 122, 123

Couch, E. J., 102

Cox, R. J., 147

Craig, R. A., 32

Crew, R. T., 26,105

Cronauer, D. C., 96

Crookston, R. B., 30

Cross, T. S., 85, 136

Crouse, D. J., 77,150 
Culbertson, W. J., Jr., 79

Cummins, J. J., $87,110,125$

Curtin, D. J., 29

Dailey, J. L., 130

Dana, G. F., 62, 126

Dancy, T. E., 90

Davis, A. J., 96

Dayton, S. H., 132

Decora, A. W. , 26,36,47,52,56,58, $100,101,115$

Department of Interior Staff, 62,63

Dickson, E. M., 114

Dinneen, G. U., $82,85,88,134$, 148,149

DiSante, E., 30

Doggett, J. N., 100

Donnel1, J. R., 66, 124,131,143

Donovan, R. P., 23

Doolittle, F. G., 60,110

Dougan, J.L., 136

Dougan, P. M., 135, 145

Doyle, W. S., 30

Duff, M. K., 112

Duffield, W. J., 60

Duva11, J. J., 70,111

Earnshaw, P. G., 79

East, J.H., Jr., 87

Eglinton, G., 49

Eliason, M. D., 100

Ellington, R. T., 123,133

Ellzey, V., 45

Ely, N. 83

Ensminger, A., 49

Ertl, T., 138

Everhert, W. H., 63

Fausett, D. W., i00

Felder, R. M., 23

Feldkirchner, H. L., $96,119,121$

Ferris, B. J., 90

Findeis, A. F., 55

Findley, J. E., 27

Fischer, R. C., 47

Fletcher, K. J., 63

Frank, M. E., 106

Fojo, C. V., 33

Foster, J. I., 69

Frost, C. M., 53,96,111,112,124

Futa, K., 120
Gala, K., 26

Gallegos, E. J., 32

Garcia, M., Jr., 23

Gardner, E. D., 87

Gary, J. H. , 32

Geidroyc, V., 90

Gelpi, E., 74

Geology Society of America Staff, 112

George, A. E., 96

Gilmore, J. S., 112

Giltner, R. E., 47

Glenn, W. E., 113

Globe, S., 32

Goodfellow, L., 47,113

Gorin, E., 97

Grant, B. F., 113,140

Greensmith, J. T., 144

Grimes, W. R., 150

Grimmer, G., 32

Guthrie, B., 141

Haas, F. C., 33

Haines, W. E., 85

Ha 11, H. J., 64

Hand, J. W., 80

Hanson, R. L., 101

Harris, F. L., 70

Hartley, F. L., 47,146

Haworth, G. R., 73,127

Hedval1, J. A., 150

Heley, W., 48, 113

Hemmen, G. A., 146

Henderson, W., 71,74

Hendrickson, T. A., 48, 114

Hepner, L. S., 142

Herkenhoff, E. C. , 69,71,126

Herre11, A. Y., 101

Hester, J. J., 47

Higa, J. A., 26

Hi11, G. R., 135,136

Hohnson, D. H., 136

Hollingshead, R. D., 79

Holm, M. M., 128

Hope, E. H., 71

Horne, J. W., 150

Hoskins, W. N., 33

Howe, C. W., 69

Hubbard, A. B., 74,90,139

Hughes, E. E., 33,114 
Hundemann, A. S., 23

Hurst, F. J., 150

Hutchins, J. S., 75

Jackson, L. P., 35, 36,48, 101

Jacobson, I. A., Jr., 26,44,115, 129

Jaffe, F. C., 87, 142

Jensen, $\dot{H}$. B. $, 26,35,39,48,53,55,56,70$,

$71,75,76,79,82,88,96,111,112,124,129$ Jensen, R. K., 96

Jesse, D. R., 84,136

Jewe 1 1, D. M., 96

Johansen, R. T., 96,117

Johnson, D. R., 131,137

Johnson, H. R., 34,58

Johnson, W. F., 42,102

Jones, W. J., 117

Ka1ter, R. J., 34

Kate11, S. 49,115,127,129

Keighin, C. W., 102

Keller, H. H., 102

Kerr, R. S., 52

Kessler, M. M., 117

Kilburn, P. D., 24,49,60

Kilker, C., 36

Kim, K. E., 26

Kimble, B. J., 49

King, R. U., 133

Kinney, I. W., Jr., 89

Kirkpatrick, L. W., 115

Kittrick, J. A., 71

Klass, D. L., 103

Krech, W. W., 75

Kreider, J. F., 69

Kuhn, E. A., 55

Kuncha 1, K. S., 103

Larson, M. , 148

Lawlor, D. L., 87

Leach, H. J., 35, 103

Leffler, L. , 26

Legatski, M. W. , 75

Lekas, M. A., 137,139

Lewis, A. E., 35

Leythaeuser, D., 64

Ligon, D. R., 36

Linden, H. R., 50,135

Livingston, C. W. , 47,50,116,124

Löf, G. 0. G., 77

Lovering, T. G., 80
Magee, E. M., 64

McCaslin, B. D., 60,66

McDermott, J., 127

McDona 1d, F. R., 51,79

Mapstone, G. E., 89,90,91,92,93

Margheim, G. A., 77

Marschner, R. F., 97

Marsha 11, P. W., 37,47,51,116

Maxwe 11, J. R., 49

May, B. E., 63

Mayer, J. F., 41

Melton, N. M., 85, 136

Metz, W. D., 51

Meyer, J. W., 117

Meyer, W. C., 26,51,96

Miknis, F. P., 26,52

Mil1er, J. S., 96,117,130

Miller, L., 136

Miller, P. G., 104

Mock, H. B., 83

Mode11, M., 41

Montgomery, D. P., 83,96

Morandi, J. R., 37,70

Moschopedis, S. E., 97

Moussavi, M., 27,96,117

Murphy, W. I. R., 147,150

Murray, R. G. , 33

Murthy, K., 45

Myers, G. A., 29

Nartsissov, B., 89

National Petroleum Council Staff, 70

Nevens, T. D., 79

Nickerson, L. G., 99

Nielsen, I. , 65

Nordengren, S., 150

Novak, A., 24,95

Oklahoma University Staff, 104

01 iver, W. B., 65

Ourisson, G., 49

Paxton, J., 38

Penner, S. S., 38

Perrini, E. M., 104

Persse, F. H., 38

Peterson, G. R., 150

Petzrick, P. A., 39

Pfeffer, F. M., 52

Pforzheimer, H., 52,118 
Philip, R. P., 49

Phillips, T. E., 35

Piku1, R. P., 52

Piper, E. M., 53

Pitman, J. K., 66, 124

Poulson, R. E., 26, 35, 37, 39,53, $56,70,71,75,76,80,96,112,129$

Prien, C. H., 27,54

Rabin, R., 52

Radian Corporation Staff, 105

Rammler, R. W., 131,132

Redford, D. A. 96

Reed, H., 152

Reed, P. R. Jr., 47,53

Reinecke, S. E., 72

Reynolds, F. S., 145

Ridley, R. D., 105,118

Riley, R. G., 95

Robb, W. A., 107,124,127

Robinson, W. E., 40,60,66,69,76, $81,87,90,110,122,125,145$

Rogers, H. H., 23

Rogers, M. P., 53

Rold, J. W., 119

Root, P. J., 145

Rosenhoover, W. A., 97

Rothman, A. J., 40,98,105

Routson, R. C., 24,25,41,71

Ruark, J. R., 76, 149

Rubel, A. C., 88

Rudrum, M., 78

Russe 11, P. L., 53,133

Rutledge, P. A., 105

Ruberto, R. G., 96

Sandberg, C. B., 33

Sanderson, R. T., 146

Sarapuu, E., 140

Satterfield, C. ii., 41

Sawatzky, H., 96

Schaal, L., 60

Schlinger, W. G., 84,136

Schmeh1, W. R., 60,66

Schmidt, R. A., 114

Schmidt-Collerus, J. J., 26,27,54

Schmitt, J. M., 150

Schoental, R., 93

Schora, F. C., Jr., 119

Schramm, L. W., 132

Schyanberg, E. K., 145

Science Policy Research

Division Staff, 67
Scrima, D. A., 55

Seelig, H. S., 148

Sheridan, M. J., 133

Sellers, J. B., 73,127

Sherwin, M. B., 106

Shih, S., 26,59

Siggia, S., 55

Silver, H. F., 26,56,71

Sladek, T. A., 42,57

Smiley, G. T., 96

Smith, C. D., 57,120

Smith, J. R., 88,89

Smith, J. W., 62,84,87,107, $120,124,126,127,131,137$

Smith, R. H., 68

Snider, D., 56

Snyder, L. R., 84

Snyder, P. W., Jr., 42

Sohns, H. W. , 45, 47, $76,82,108$, $134,138,147$

Sparks, F. L., 58

Spedding, T. J., 35

Speight, J. G., 97

Spence, H. M. , 58

Spiess, E. R., 86

Stanfield, K. E., 84,134,145,150

Stanford Research Institute Staff, 95

Stee1, G., 71,74

Sterner, T. E., 61

Stevens, R. F., 149

Stone, R. T., 49,58

Subcommittee on Energy - U.S.

House of Representatives

Staff, 59

Sweeton, F. H., 106

Sylvester, R. D., 106

Tarman, P. B., 96,119,121

Thorne, H. M., 148,150

Tihen, S. S., 82,108

Timmins, T. H., 42

Tobie, R. L., 33

Trude11, L. G. , 84, 120,127

Tyler, A. L., 121

Tyner, W. E., 34

Uden, P. C. , 55

Udis, B., 69

Upadhyay, R. P., 33

Scott, W. G., 130 
Vandenberg, M. L. J., 107

Vanderborgh, N. E., 101

Varisco, D. C., 99

Vawter, R. G., 26

Voegeli, P. T., 133

Vysamyae, A. I., 107

Walton, D. K., 102

Wang, N. H., 26,56,71

Ward, J. C., 72,77

Warren, P. L., 47,53,55

Weichmann, B., 121

We 11 , S. A., $96,119,121$

Wel 1 man, P., 49,115,127,129

Wells, W. E., 149

Wen, E. S., 26

Wethington, J. A., Jr., 72

Whitcombe, J. A., 26

White, R. K., 33

Williams, F. E., 133

Wil1 iamson, D. R., 140,141,142

Winters, J. C., 97

Woolnough, W. G., 152

Wright, F. D., 33

Wszolek, P. C., 74

Wunderlich, D. K., 29

Wyoming Water Resources Research

Institute Staff, 107

Yang, E., 74

Yardumian, L. H., 45, 108

Yen, T. F., 26, 27, 51, 55, 56, 59, 96, 117

Young, D. K., 26,59,96,117

Young, N. B., 87,107

Zambas, P. G., 73,127

Zielke, C. W., 97

Zitting, R. T., 42,122 
BNWL-2200

UC-91

DISTRIBUTION

No. of

Copies

OFFSITE

D. S. Balantine

Division of Biomedical and

Environmental Research

Department of Energy

Washington, DC 20545

A. A. Churm

DOE - Chicago Patent Group 9880 South Cass Avenue

Argonne, IL 60439

194 DOE Technical Information

Center

P. Fox

621 Davis Hall

University of California

Berkeley, CA 94720

5 R. E. Franklin

Division of Biomedical and Environmental Research

Department of Energy

Washington, DC 20545

E. A. Jenne

Water Resources Division

U. S. Geological Survey

345 Middlefield Road

Men1o Park, CA 94025

W. T. Piver

NIEHS

P. 0. Box 12233

Research Triangle

Park, NC 27709

A. J. Rothman

Earth Sciences, K Division University of California

Lawrence Livermore Labs

P. 0. Box 808

Livermore, CA 94550
No. of

Copies

OFFSITE

R. L. Watters

Ecological Sciences Branch

Division of Biomedical and

Environmental Research

Department of Energy

Washington, DC 20545

J. H. Weber

Department of Energy

Laramie Energy Research Center

P. 0. Box 3395

University Station

Laramie, WY 82071

T. F. Yen

Department of Chemical

Engineering

University of Southern

California

Los Angeles, CA 90007

ONSITE

DOE - Richland Operations Office

H. E. Ransom

Battelle-Northwest

T. W. Ambrose

W. Bair

10

R. M. Bean

S. H. Bush

D. B. Cearlock

H. Drucker

W. D. Felix

R. F. Foster

T. R. Garland

S. Marks

R. W. Perkins

M. R. Petersen 
ONSITE contd.

Battelle-Northwest contd.

\author{
W. H. Rickard \\ R. G. Riley \\ J. E. Rogers \\ P. W. Ryan \\ R. H. Sauer \\ L. C. Schmid \\ M. H. Schneider \\ N. M. Sherer \\ J. A. Strand \\ W. L. Templeton \\ B. E. Vaughan \\ P. C. Walkup \\ D. G. Watson \\ R. E. Wildung \\ W. R. Wiley \\ 3 Technical Information \\ 2 Technical Publications \\ Rockwe11 Hanford Operations
}

45 R. C. Routson 